\author{
UNIVERSIDADE DE SÃO PAULO \\ FACULDADE DE FILOSOFIA, LETRAS E CIÊNCIAS HUMANAS \\ DEPARTAMENTO DE CIÊNCIA POLÍTICA
}

JOYCE HELLEN LUZ

POLÍTICA MINISTERIAL: AS EMENDAS INDIVIDUAIS ORÇAMENTÁRIAS NO PRESIDENCIALISMO DE COALIZÃO BRASILEIRO 


\section{POLÍTICA MINISTERIAL: AS EMENDAS INDIVIDUAIS ORÇAMENTÁRIAS NO PRESIDENCIALISMO DE COALIZÃO BRASILEIRO}

Dissertação apresentada ao Programa de PósGraduação do Departamento de Ciência Política da Universidade de São Paulo, como requisito para obtenção do título de Mestre em Ciência Política.

Orientador: Prof. Dr. Fernando Limongi

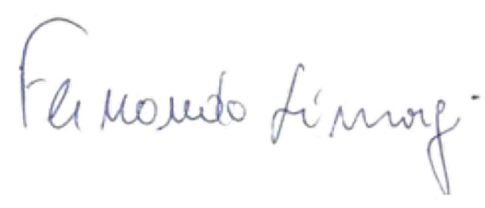

De acordo com a revisão São Paulo, 26 de Outubro de 2017

Versão Corrigida

SÃO PAULO

2017 
Autorizo a reprodução e divulgação total ou parcial deste trabalho, por qualquer meio convencional ou eletrônico, para fins de estudo e pesquisa, desde que citada a fonte.

Catalogação na Publicação

Serviço de Biblioteca e Documentação

Faculdade de Filosofia, Letras e Ciências Humanas da Universidade de São Paulo

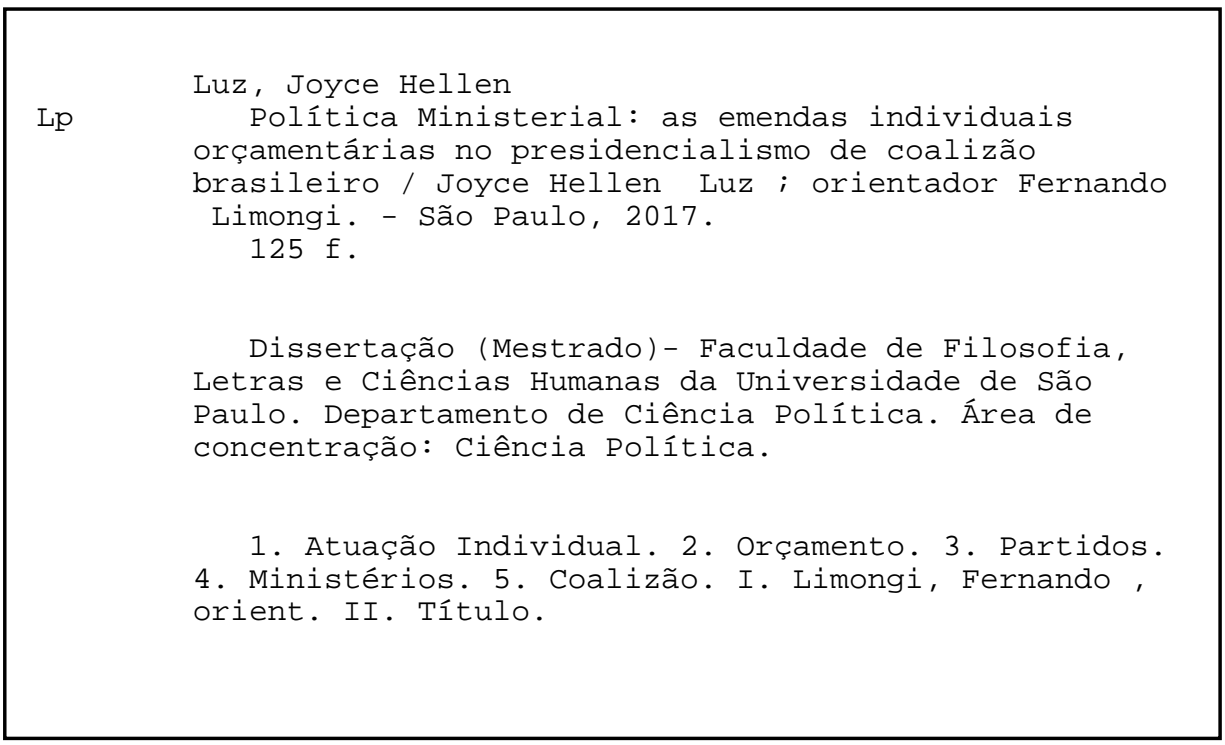


Nome: LUZ, Joyce Hellen

Título: Política ministerial: as emendas individuais orçamentárias no presidencialismo de coalizão brasileiro ${ }^{1}$

Dissertação apresentada ao Programa de PósGraduação do Departamento de Ciência Política da Universidade de São Paulo, como requisito para obtenção do título de Mestre em Ciência Política.

Orientador: Prof. Dr. Fernando Limongi

Aprovada em:

Banca Examinadora

Professor Dr.:

Instituição:

Julgamento:

Assinatura:

Professor Dr.:

Instituição:

Julgamento:

Assinatura:

Professor Dr.:

Instituição:

Julgamento:

Assinatura:

\footnotetext{
${ }^{1}$ Agradeço a Fundação de Amparo à Pesquisa do Estado de São Paulo (FAPESP) por ter concedido a bolsa de mestrado e pelo apoio financeiro (processo 2014/24759-9) para a realização desta pesquisa. As opiniões, hipóteses e conclusões ou recomendações expressas neste material são de responsabilidade da autora e não necessariamente refletem a visão da FAPESP.
} 
Aos melhores pais que me escolheram, Solange e Wagner Ao meu irmão, Yan Ao pequeno Théo, que deixa minha vida mais colorida E ao time de amigos Cebrap/ NECI, À todos vocês com muito amor. 


\section{AGRADECIMENTOS}

"Não é sobre chegar no topo do mundo e saber que venceu. É sobre escalar e sentir que o caminho te fortaleceu. É sobre ser abrigo e também ter morada em outros corações e, assim, ter amigos contigo em todas as situações. A gente não pode ter tudo. Qual seria a graça do mundo se fosse assim? Por isso eu prefiro sorrisos e os presentes que a vida trouxe para perto de mim. Não é sobre tudo o que o seu dinheiro é capaz de comprar. E sim sobre cada momento, sorriso a se compartilhar. Também não é sobre correr contra o tempo para ter sempre mais. Porque quando menos se espera a vida já ficou para trás".

(Trem-Bala, Ana Vilela)

Estou quase a dois meses de entregar essa dissertação. Fecho meus olhos. Respiro e penso: vai dar tempo. Abro novamente meus olhos. Me sinto sozinha como a maioria das pessoas que passam por isso costumam relatar durante esse processo. A essa altura do campeonato percebo que faz mais de seis meses que, no mínimo, por cinco dias da semana minha rotina tem sido eu, a tela do computador e as palavras nessas páginas. Aparentemente formo um time nada brilhante e promissor de uma pessoa. $\mathrm{O}$ coração acelera. A respiração fica mais ofegante. Fecho os olhos novamente. E um turbilhão de pensamentos invadem o espaço. Casa, família, trabalho, dissertação, frustrações, pressões, cobranças, medos. Será que vou dar conta? Não, claramente eu não vou conseguir lidar com tudo isso ao mesmo tempo. Tem muita coisa acontecendo ao mesmo tempo. Respiro e penso: você precisa se acalmar. Com os olhos fechados eu já consigo sentir as lágrimas vindo, por mais uma vez. Sou interrompida. Alguém abre a porta do NECI. Abro novamente os olhos. E pronto. A sensação de estar sozinha desaparece. Ufa! Durou poucos segundos. E eu volto a me lembrar de como eu sou imensamente grata. E de como tenho sorte por não estar sozinha. Por não precisar lidar com tudo isso sozinha. Sempre tive um time completo em campo. Eu vou conseguir. E eu consegui. Por eles e com eles eu digo, sem medo algum: valeu a pena!

$* * *$

Gratidão:

1- Sentimento de reconhecimento, uma emoção por saber que uma pessoa fez uma boa ação, um auxílio, em favor de outra;

2- É querer agradecer a outra pessoa por ter feito algo muito benéfico para ela;

(Dicionário Aurélio) 
Apesar do Dicionário Aurélio e do próprio Google retornarem o significado da palavra gratidão, eu acredito fortemente que nenhuma definição que eu colocar aqui nessas páginas será suficiente para transmitir de fato o que eu estou sentindo nesse exato momento. É uma tarefa quase que impossível, e um pouco injusta também, a de tentar deixar registrado aqui nessas páginas um sentimento que simplesmente transborda no meu coração. Recebi tanto apoio e tanto carinho em todos os momentos e etapas deste trabalho que só as palavras que aqui serão colocadas, infelizmente, não darão conta de transmitir o tamanho da minha gratidão por tantas pessoas e momentos bons que vivi até aqui.

Começo essa árdua, mas muito prazerosa, tarefa de agradecer com um agradecimento a uma pessoa muito especial que me trouxe até aqui. Danilo, não sei o quanto vou ser capaz de te agradecer por você ter me escolhido naquela entrevista. Minha vida mudou muito desde então. Lembro até hoje que fui sincera e te disse que não sabia nada sobre Legislativo. E você sorriu e disse que você só estava buscando alguém que estivesse disposta a aprender. E de lá para cá, meu amigo, eu ganhei muito mais do que um aprendizado sobre Legislativo. Aprendi a trabalhar em um grupo que se tornou minha segunda família, aprendi a mexer e fazer consultas mirabolantes no Access, aprendi a andar em São Paulo (e recentemente a comer a melhor coxinha que essa cidade oferece!) e o mais importante: aprendi como era fazer uma amizade e como mantê-la mesmo com quilômetros de distância e vários países nos separando. Meu carinho e admiração por você são enormes! E eu espero que um dia eu consiga retribuir a altura tudo o que você já fez e continua fazendo por mim. Esse trabalho tem muito do que aprendi com você.

Nessa mesma trajetória de carinho e admiração eu devo um agradecimento a Andréa Freitas. Andréa, tive o prazer e a sorte de dividir com você várias etapas. Eu conheci a Andréa monitora de Política I, a Andréa coordenadora de um núcleo de pesquisa, a Andréa doutoranda, a Andréa aluna de pós-doutorado, a Andréa pesquisadora, a Andréa professora e a Andréa mãe. Imagino eu, que ainda tenha outras Andréas que eu não conheço. Mas com todas essas Andréas que eu conheci, até agora, eu aprendi muito! E esse trabalho reflete isso. Aqui dentro tem a Andréa que me ensinou a escrever ainda no meu primeiro ano de graduação, a Andréa pesquisadora que me ensinou a mexer com dados, a Andréa professora que participou da minha qualificação e me guiou pelo caminho da coordenação partidária, a Andréa doutoranda e pesquisadora que me mostrou que fazer pesquisa não é fácil, mas que é possível e, finalmente, tem muito da Andréa mãe que, um dia no NECI, passou a mão na minha cabeça e disse que no final tudo iria 
ficar bem. E desde então eu sigo com essa certeza. Andréa, sua trajetória e dedicação para com todos é uma inspiração! Sou imensamente grata por todo aprendizado que você me passou e espero continuar a ter essa sorte grande e prazerosa que é a de aprender com você! Não tenha dúvidas que meu carinho por você é enorme.

Aqui também aproveito para fazer um agradecimento ao Professor e amigo (se me permite o considerar assim) Glauco Peres. Glauco, agradeço muito por você ter participado da minha qualificação e me ajudado a clarear tantas ideias que ainda estavam confusas. Agradeço também pelas inúmeras vezes em que bati na sua porta ou te abordei no NECI para tirar dúvidas sobre qual a melhor forma de apresentar e interpretar os meus dados. Para além disso, como mencionei, eu devo um agradecimento mais do que especial ao Glauco amigo que manteve seus braços, horários de almoço e café sempre abertos para receber a Joyce com suas angústias e aflições. Glauco, com você eu tive conversas e recebi abraços que contribuíram muito para que eu me mantivesse sã ao longo da produção desse trabalho. Encontrar professores tão dispostos a ensinar os alunos e, sobretudo, a ajudá-los é uma raridade. E mais uma vez que me considero muito sortuda por você ter compartilhado o seu melhor comigo.

No time de professores eu também devo um agradecimento ao professor Adrian Lavalle que ainda no meu primeiro ano do mestrado ministrou uma das disciplinas que mais contribuíram para que eu pudesse repensar questões teóricas e empíricas sobre o meu tema de pesquisa. Também agradeço imensamente a professora Marta Arretche pela disposição em ensinar a seus alunos como ler, verdadeiramente e sob um olhar crítico, os textos tão necessários para a realização de nossas pesquisas, e pelo apoio e palavras de incentivo que recebi para finalizar esse trabalho.

Passo agora para um agradecimento mais do que especial e necessário aqui. Não é e nem será uma tarefa fácil a de agradecer a minha segunda família e ao melhor time de pesquisadores no qual eu tenho a honra e a imensa alegria de fazer parte. De uma forma geral, mas absolutamente nada trivial, é que eu afirmo que eu não teria conseguido chegar até aqui sem as pessoas maravilhosas e incríveis com que tenho o prazer de dividir meu dia a dia: meus queridos amigos do Cebrap/NECI, saibam que essa dissertação não seria nada sem vocês e que meu coração transborda de tanta alegria por saber que tenho vocês comigo!

Mini Andréa (também conhecida como Andréa Junqueira ou Andreazinha), a verdade é que faltam palavras para conseguir explicar o meu sentimento de amor e carinho por você. Eu só consigo parar e pensar no quanto ficamos próximas nos últimos 
quatro anos. No quanto caminhamos sempre juntas. No quanto você foi meu apoio em vários momentos dentro e fora do NECI. Dividir o final da graduação, o mestrado, o dia a dia do NECI, as jantas, os almoços, as corridas, as festas e essa última etapa de escrever uma dissertação com você é o maior presente que a vida poderia ter me proporcionado! Você vive me falando que eu tenho um coração enorme, mas a verdade é que você é a ariana com o maior coração que eu já tive a sorte de dividir meu tempo, carinho, amor e amizade. Você é a pessoa que mais me conhece. Vamos terminar essa etapa, mais uma vez, juntas! Nós conseguimos! E eu só consegui, porque você sempre esteve lá. Te amo muito! Obrigada por tudo até aqui. E sigamos sempre juntas rumo ao infinito e além.

Também devo um agradecimento mais do que especial aos meus outros dois parceiros favoritos de mestrado: Fer e Cássio. Fer, Fernanda, Pequena II, seu coração é tão enorme que eu não sou capaz de descrever. E apesar de você não acreditar muito, eu tenho certeza de que seu coração é tão grande quanto toda a força que você carrega dentro de si. Nunca vi uma pessoa tão pequena, como eu, com tanta força e persistência! Sou imensamente grata por toda admiração, cuidado, afeto, caderninhos (lindos!) e carinho que você sempre demonstrou por mim! Obrigada por tudo, de coração!

Cássio, sei que você nunca me perdoou pelo "O Cássio que leve o dele". Espero que você possa me perdoar um dia por isso (risos). Mas falando sério agora: eu espero de verdade que você um dia consiga perceber ou entender o quanto todos os seus abraços foram não só acolhedores, mas também essenciais para me confortar em tantos momentos. Eu sou imensamente grata e um dia espero conseguir retribuir todas as conversas e desabafos que você já teve comigo. Eu não consigo mais imaginar como é chegar ao NECI e não receber um abracinho seu. Obrigada pela amizade e carinho de sempre.

Indo ainda mais fundo, eu tenho que agradecer a Graziele Silotto que eu prefiro, carinhosamente, chamar de Grazi. Você é, com toda certeza, a pessoa que mais tempo passou comigo desde que entramos juntas para esse time. Com você dividi muitas histórias - felizes e tristes -, muitas viagens (Hoyce, rolou!), muitos almoços, muitos jantares, muitos cafés (desde a época em que não tomávamos cafés) e muitos trabalhos. A Hoyce aqui sente que é uma pessoa muito melhor e mais feliz por ter tido você por tanto tempo ao meu lado. Obrigada de coração, por toda amizade, tempo e carinho gastos comigo. A Hoyce aqui também tem muito carinho guardado por você.

Samir, eu gostaria que você soubesse que você foi uma das pessoas mais do que essenciais para eu concluísse esse trabalho. Inúmeras vezes você me disse que não sabia 
como me ajudar e eu, agora, só gostaria de conseguir mostrar como você ajudou e muito. Um abraço forte, como os que você sempre me deu, vai ser insuficiente para te agradecer por sempre ter me dito que eu era uma pessoa incrível e, por nessa reta final, ter secado tantas vezes as minhas lágrimas. Você é uma pessoa que carrega uma simpatia e uma bondade que são ímpares, Samir. Eu desejo que outras pessoas, inclusive você, tenham a sorte de encontrar um amigo assim!

Todos os gráficos que estão aqui nessa dissertação eu dedico com muito carinho ao Maurício, ou R-Lover. Muito obrigada por ter me ensinado não só a mexer no $\mathrm{R}$, mas também por toda a amizade e carinho - que mesmo de maneira tímida - eu sei que você carrega. É por poder aprender R com você, ir bandejar às 11 horas da manhã e saber que você sempre está disposto a ouvir todas as minhas histórias que eu sou imensamente grata pela sua companhia e amizade.

Patrick, queria tanto que você estivesse aqui por perto só para que eu pudesse te abraçar e te agradecer pelos inúmeros conselhos que recebi não só quanto a vida acadêmica, mas também em relação a minha vida pessoal. Obrigada por todo carinho e cuidado comigo. Obrigada por mesmo distante ter lido e comentado não só minha qualificação, como também dois dos capítulos dessa dissertação. Obrigada também por ter me considerado uma pessoa à altura para te substituir no Blog Legis-Ativo. Sou uma pessoa bem mais feliz por saber que posso contar com um amigo como você. Também aproveito para a agradecer pelo carinho que a Jú sempre teve comigo. Saudades de vocês.

E finalmente, mas não menos importante, eu devo um agradecimento a Juliana ou como eu costumo carinhosamente chamar de Jú. Eu devo confessar que foi difícil decidir em qual parte dos meus agradecimentos você estaria presente. Em tão pouco tempo você adentrou em tantas esferas da minha vida que eu poderia escrever, tranquilamente, uma página inteira de agradecimentos só direcionados para você. Você é uma das pessoas pelas quais eu sou imensamente grata de a vida ter nos colocado frente a frente. Pessoa com uma integridade única, com uma história e experiência de vida inexplicável, com uma força de vontade indescritível e com um papel essencial de ter mudado tanto a minha vida para melhor. Com você e graças a você Jú, eu descobri uma força que nunca achei que iria encontrar dentro de mim, eu comecei a me cuidar mais (Campanha Juliana musa fitness e que traz saúde para o NECI), eu aprendi a correr, eu acreditei mais no meu potencial como pesquisadora, eu entendi o quanto eu não devo exigir e nem deixar que os outros exijam tanto de mim. Eu aprendi a me amar sendo eu mesma. Fora isso, nós duas sabemos (ou eu espero que você saiba) que em um dos momentos em que mais 
precisei nessa reta final você me deu a força necessária para chegar até aqui. Quebramos tantas barreiras juntas, descontruímos tantos preconceitos juntas, passamos por tanta coisa juntas que eu espero, sinceramente, ter a sorte de continuar a dividir meus dias com uma pessoa tão especial e iluminada quanto você.

Aos jovens pesquisadores do Cebrap/NECI eu gostaria que todos vocês soubessem o quanto eu tenho o orgulho de vocês e como vocês fazem eu ser uma pessoa bem mais feliz ao dividir meu dia a dia de trabalho com vocês. Eu aprendo muito mais dividindo meu tempo com vocês. Obrigada por nessa reta final terem parado tantas vezes o trabalho de vocês para me ajudarem na construção e discussão de argumentos e para olharem meus dados. Meu carinho e afeto por vocês são enormes!

Lelexia (ou também Alexia), gostaria de te agradecer pelo carinho, pelas conversas, pelas risadas, pelos jantares, pelas idas ao shopping pós trabalho, pelas inúmeras caronas e por não ter esquecido da minha pessoa nesse último ano distante. Leléo (Leonardo ou também Bebê Brilhante), meu coração transborda tamanho é meu carinho por você! Obrigada pelas inúmeras mensagens diárias me perguntando se eu estava bem, pelas conversas de desabafo, pelas caronas tarde da noite e pelos fones de ouvido que garantiram o silêncio necessário para escrever essa dissertação.

Ana, minha pupila, minha primeira parceira de trabalho do tão complexo banco do orçamento. Fico feliz demais em te ter por perto! Muito obrigada pela leitura sempre atenta dos meus trabalhos, pelos incentivos e por sempre acreditar em mim. Pode ter certeza que hoje sou eu quem aprende muito com você. Ter você ao meu lado e ver você progredindo a cada dia mais enche meu coração de alegria.

Ligiane, Vanessa e Nathan, vocês são os caçulas do Legislativo e ver vocês indo adiante, progredindo me proporciona uma alegria enorme e indescritível. Além disso, a disposição e vontade que vocês demonstraram para me ajudar nesse tempo todo fazem com que eu tenha ainda mais certeza de que vocês são pessoas mais do que merecedoras para compor esse grande time que nós somos. Muito obrigada por estarem comigo! Eu tenho o maior orgulho e carinho por vocês! Gi (minha musa dos cachos), Camila, Gabriel Z. e Rodrigo, sei que vocês não são originalmente do time Legislativo, mas isso não diminui em nada o afeto que tenho por vocês. Com vocês tive e tenho conversas que tornam o meu dia a dia bem mais prazeroso e produtivo. Sou muito feliz por ter vocês com a gente.

Finalizando os agradecimentos do time Cebrap/NECI, eu agradeço imensamente ao Pedro por sempre se mostrar disposto a me ajudar e pelas inúmeras histórias de 
aventura que me inspiram. Ao Paulo por ter tirado tantas dúvidas minhas sobre estatística e sobre banco de dados e ao Flávio pela breve passagem, mas pelas grandes "Fiestas". Mais recentemente, agradeço ao mais novo jogador do time, Davi Moreira, por ter tido muita paciência e me aconselhado inúmeras vezes a colocar um ponto final nessa dissertação. Também agradeço ao Samu pela animação e empolgação de sempre e a Lara Mesquita por ter me ajudado a dar meus primeiros passos nessa seara do orçamento.

Dentre as amigas e colegas de departamento, agradeço muito pelo carinho de mulheres mais do que especiais que me inspiram não só academicamente, mas também pela força e garra que têm: Hellen, obrigada por uma das melhores conversas sobre os percalços da vida. Saiba que te admiro muito, muito mesmo! Você sempre foi e vai continuar a ser uma inspiração! Dani, Hannah e Marina, obrigada pelo carinho, pela compreensão e pelos ensinamentos de sempre. Vocês são mulheres incríveis com quem tenho a sorte imensa de aprender. Telma, Gabi, Graziela Testa, Bárbara Lopes, Marcela Tulli, Natália Moreira, Renata Mendes e Raissa também agradeço muito por todos os abraços e incentivos para eu seguir em frente!

Mari, como já te disse uma vez e volto a repetir: você foi um dos maiores presentes que 2016 me reservou. Conhecer você não me fez sentir só uma alegria e felicidade imensa. Me fez sentir, também, que o mundo tem muita sorte e precisa de mais pessoas com a sua humildade, bondade, doçura e paciência. Te conhecer me faz querer ser uma pessoa melhor. Muito obrigada por sempre estar ao meu lado. Muito obrigada pelos abraços (melhores abracinhos) e por me mostrar que a vida tem muita coisa boa para ser vivida ainda. Espero sempre ter a sorte de fazer parte desse 'trem' bom demais que é ter sua amizade.

Ainda dentre os colegas de departamento também gostaria de agradecer à alguns amigos que foram essenciais em momentos específicos dessa jornada. Agradeço ao Bruno Pessoa, um amigo e tanto que tive a sorte de conhecer ainda na entrevista do mestrado. Bruno, muito obrigada pelo carinho e amizade de sempre! Muito obrigada por acreditar em mim e por me entender. Contar com a sua amizade e companhia foi fundamental para que eu chegasse até aqui. Sérgio Simoni, obrigada pela motivação nessa reta final, por acreditar no meu trabalho e, acima de tudo, por sempre ler meus trabalhos e fazer comentários incríveis! E Tiago Borges, melhor amigo de cafés, agradeço pela doçura e pela compreensão de sempre. Suas conversas sempre foram muito acolhedoras e me transmitiram muita calma e segurança. 
Também agradeço ao Paulo Flores por ter me apoiado lá no início ainda durante o processo seletivo para o mestrado (aqueles chocolates foram essenciais para me acalmar) e por sempre me incentivar a chegar na reta final. Também agradeço ao Victor Araújo que em um dos momentos mais cruciais do mestrado, na qualificação, me fez ótimas indicações de leituras e sempre se manteve à disposição para me ajudar nos trabalhos. E, por fim, também agradeço ao Jefferson Leal, ao Thiago Moreira, ao Pedro de Castro e ao Gabriel Madeira pela amizade, carinho, companhia e disposição que sempre tiveram para me ajudar.

Aos amigos externos, agradeço ao César, pelo carinho e torcida de sempre. À Ana Flávia por ser a dona do sorriso e dos abraços mais contagiantes que sempre me receberam. Aos amigos do Polbrás lá na Unicamp, Vitor, Monise, Jean e Ana Flávia, agradeço pela companhia e pelas conversas maravilhosas que sempre temos quando nos encontramos. E ao Humberto Dantas pela amizade e confiança no meu trabalho. À todos vocês muito obrigada!

Um agradecimento mais do que especial para a Márcia Staaks, que sempre me recebeu de braços abertos e resolveu meus pepinos no DCP, para o Vasne Santos que inúmeras vezes ouviu minhas reclamações e sempre me ofereceu em troca sua ajuda, bombons, balas e sorrisos e para o Léo que sempre se mostrou pronto para me ajudar. Sem vocês esse DCP não seria o mesmo. Muito obrigada pelo trabalho e dedicação.

Mais recentemente agradeço também aos meus colegas de trabalho no Cebrap. Kelly e Sandra, muito obrigada pelo carinho com o qual vocês sempre me recebem e mais do que isso, muito obrigada pelos incentivos e pela preocupação que vocês sempre têm comigo. Sou muito grata por ter a sorte de trabalhar com pessoas tão queridas como vocês! Também agradeço pelo carinho e afeto da Adilza, do Edimilson, da Bê e do Sasá.

Agradeço aos moradores do \#202 mbc por serem os melhores presentes que 2017 me reservou. Lilian, querida, espero um dia ter a capacidade de retribuir todos os abraços e palavras de apoio que recebi de você. Conhecer melhor a mulher forte, guerreira e determinada que você é, serviu de inspiração para eu parar de reclamar e erguer a cabeça para seguir adiante. Você é uma mulher incrível e tenho muita sorte de aprender tanto com você! Pirata (vulgo Camila), eu não sei mais passar uma semana sem te ver. Sua alegria, energia e modo de viver são contagiantes. Eu tenho certeza que a Joyce de hoje tem muito de você! Obrigada por ter me acolhido. E Cleyton, amigo mais recente de todos, mas que já guardo um carinho e uma admiração enorme! Obrigada por me divertir, 
pelas risadas e pela companhia de sempre. Eu agradeço muito por ser tão bem recebida em um apartamento que só tem pessoas com muito amor e braços abertos para me receber!

Também sou imensamente grata e feliz por ter e poder contar com o apoio incondicional dos meus queridos amigos jundiaienses, que nem sempre entenderam por completo os ócios e os ofícios da minha profissão, mas que nunca deixaram de acreditar em mim e no meu potencial. Jéssica e Amanda agradeço pela amizade de anos e por todo amor e momentos felizes que vocês me proporcionam. Gui, agradeço imensamente por você ter me deixado fazer parte dessa família maravilhosa e por ter me mostrado como levar a vida mais leve. Dener, obrigada por sempre me acolher e me entender em meio as minhas crises. Seus conselhos e motivação foram essenciais para que eu não me sentisse tão sozinha em São Paulo. Lodi, obrigada pelas piadas e pelas conversas sobre o futuro. Maitê e Fex obrigada pelo carinho enorme com o qual vocês sempre me trataram. E Juliana e Kauê, obrigada pela companhia, risadas e comidas de sempre! Queria que vocês soubessem que sinto muito a falta de vocês e que aguardo ansiosamente pelos finais de semana só para ter o prazer e a alegria de estar com vocês. Eu amo vocês! Obrigada por estarem comigo!

Agradeço a Carol e a Jacke por serem as melhores companhias para se dividir um lar em São Paulo. Obrigada por vocês entenderem minhas ausências, minha rotina atribulada e por sempre me receberem tão bem em nossa casa. Tenho muita sorte em dividir um lar com pessoas tão incríveis e especiais como vocês. E aqui também deixo meu agradecimento a querida amiga Celí não só por ter me apresentado a Carol e a Jacke, mas também por ter dividido comigo tantos momentos alegres no NECI.

Agradeço ao Fer (Fernando Bee) por todo apoio, amor e carinho que me proporcionou. Com certeza você é uma das pessoas que mais esteve na torcida para eu chegar aqui. E parafraseando um dos meus autores favoritos: "Não sou formada em matemática, mas sei de uma coisa: existe uma quantidade infinita de números entre o $0 \mathrm{e}$ o 1 . Tem o 0,1 e o 0,12 e o 0,112 e uma infinidade de outros. Obviamente, existe um conjunto ainda maior entre o 0 e o 2 ou entre o 0 e o 1 milhão. Alguns infinitos são maiores que outros. E você não imagina o tamanho da minha gratidão pelo nosso pequeno infinito. Eu não o trocaria por nada nesse mundo. Você me deu uma eternidade dentro dos nossos dias numerados e sou muito grata por isso" (John Green).

Já me aproximando da reta final desses agradecimentos, eu deixo os agradecimentos para pessoas mais do que essenciais nessa trajetória. Começo agradecendo ao meu orientador, professor Fernando Limongi. Professor, são quase seis 
anos de orientação e trabalho em conjunto com você. Nos últimos dois anos e meio nossa parceria se afirmou ainda mais. E eu só consigo pensar agora no quanto sou grata por todos ensinamentos, orientações, insights, conversas e apoio recebido. Tenho plena consciência que sou muito sortuda por ter tido a oportunidade e o privilégio de ser guiada por um dos autores que mais influenciaram no meu tema de pesquisa. Mas mais do que isso: eu sou uma pessoa plenamente realizada e feliz por ter encontrado um orientador que me deu o apoio necessário e incondicional em todas as etapas e momentos difíceis desse trabalho. Obrigada de coração por ter acreditado em mim e por não ter deixado eu abandonar esse barco. A confiança que você depositou e deposita em mim foram mais do que essenciais para eu remar até aqui.

Para fechar com chave de ouro, eu agradeço aos meus familiares. Agradeço imensamente a minha mãe (ou como costumo carinhosamente chamar, mocinha) por ter suportado comigo todas as angústias e pressões que envolveram essa reta final. Obrigada por ter sido minha primeira professora e por ter me proporcionado o gosto pela leitura que foi tão essencial quanto necessário para que eu chegasse até aqui. Obrigada também por ser tão guerreira e me passar tanta força! Também agradeço ao meu pai, que carinhosamente chamo de Wá. Sei que você deixou seus próprios estudos de lado para ser capaz de me dar a oportunidade de ter uma faculdade e agora um mestrado. Sei das inúmeras horas extras e do cansaço físico que muitas vezes você suportou para que eu estivesse aqui hoje. Eu sei que essas páginas não amenizam todo esse esforço e desgaste. Mas eu espero de coração que elas façam você sentir que valeu a pena. Espero que vocês dois saibam que amo muito vocês e tenho um orgulho e uma gratidão enorme por ter vocês como pais.

Agradeço também à minha inspiração e motivação: ao meu irmão, Yan. Você sempre esteve a minha frente para me defender e me proporcionar o melhor. Você sempre acreditou em mim e entendeu perfeitamente o meu trabalho e a minha rotina. Você me deu o pequeno Théo, que deixa minha vida bem mais alegre e feliz. Você com certeza é a pessoa que mais acredita em mim e me incentiva para ir adiante sem ter medo. Você só me traz coisas boas! Obrigada por tudo! Amo muito você!

E, por fim, agradeço a minha avó Neusa pelos melhores bolos, cafés da tarde e orações que fez por mim. Agradeço pelo abraço e carinho de vó sempre acolhedores. E a minha tia Sandra pelo amor e carinho de mãe que sempre demonstrou por mim. Vocês são, junto com a minha mãe, as mulheres que inspiram a minha vida! 
Agradeço a Fundação de Amparo à Pesquisa do Estado de São Paulo (FAPESP) por ter concedido a bolsa de mestrado e pelo apoio financeiro (processo 2014/ 24759-9) para a realização desta pesquisa.

"Para se manter em pé, para se manter em paz. Um pouco mais de fé nunca é demais" (Autor desconhecido) 
Parties have a functional value not just from the point of view of the system, but also from view of individuals members. Parties therefore help further the self-interest of those legislators (BOWLER, 2002, p. 159). 


\section{RESUMO}

LUZ, J. H. (2017). Política ministerial: as emendas individuais orçamentárias no presidencialismo de coalizão brasileiro. Dissertação de Mestrado. Faculdade de Filosofia, Letras e Ciências Humanas, Universidade de São Paulo, São Paulo.

Os estudos a respeito do funcionamento do Congresso brasileiro não deixariam dúvidas: os trabalhos no interior da arena legislativa são organizados em termos partidários. Os atores políticos raramente conseguem agir individualmente. Partidos políticos estruturam e viabilizam a atuação dos parlamentares. Contudo, a despeito deste acordo sobre a importância dos partidos, haveria um momento específico do processo político em que os parlamentares conseguiriam agir individualmente, sem sofrer os constrangimentos dos partidos políticos: na alteração do orçamento. Seria esse o momento ideal para que os parlamentares ajam informados exclusivamente por seu interesse individual. Seria este também o momento oportuno para que o Executivo negocie com os parlamentares para obter o apoio que necessita para aprovar matérias. Os partidos sairiam de cena e o parlamentar individual viria para o centro do palco. Esse trabalho, no entanto, segue na contramão dessa vertente argumentativa e buscará mostrar como até nesse momento de atuação individual, a presença dos partidos políticos não apenas pode ser detectada, como ainda se mostra crucial. O objetivo geral aqui será o de mostrar como os parlamentares atuam por meio de seus partidos políticos ao promoverem alterações no orçamento.

Palavras-chave: Atuação individual; Orçamento; Partidos, Ministérios; Coalizão. 


\begin{abstract}
LUZ, J. H. (2017). Ministerial policy: individual budget amendments in the Brazilian coalition Presidentialism. Dissertação de Mestrado. Faculdade de Filosofia, Letras e Ciências Humanas, Universidade de São Paulo, São Paulo.

The literature on the decision-making process in the Brazilian Congress asserts that partisanship is the main factor organizing the legislative arena. Brazilian legislators are rarely able to act individually (i.e. without the support and authorization of their party leaders). However, in spite of this agreement on the importance of the parties, part of the literature also states that members of congress have the ability to operate without suffering the constraints of political parties in amending the budget bill introduced by the Executive at this crucial moment of the legislative process. Individual interests should show up exactly at this crucial moment of the legislative process. Moreover, the budget-making process should configure an excellent opportunity for the Executive to negotiate with legislators in order to obtain support for its own policy agenda. By this argument parties are absent and legislators, as individuals, would come to the center of the stage. My work, however, goes against this perspective and seeks to show the reasons why even when one should expect individual behavior, political parties show their strength and importance. My overall goal is to demonstrate that, against the expectations, partisanship matters for the budget-making process in Brazil.
\end{abstract}

Keywords: Individual action; Budget; Parties; Ministries; Coalition. 


\section{LISTA DE ANEXOS}

Anexo 1: Coalizões governamentais no Brasil (1988-2014) ...................................... 120

Anexo 2: Ministérios que mais recebem recursos para executar emendas.................. 121

Anexo 3: Destino das emendas individuais dos parlamentares que não pertencem a base do governo de acordo com os Ministérios que mais detém recursos em Investimentos (1995-2010) 


\section{LISTA DE FIGURAS}

Figura 1: Processo de Elaboração das Principais Leis Orçamentárias ........................... 29

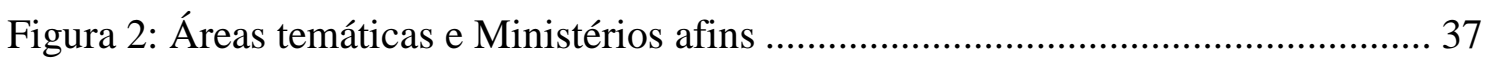

Figura 3: Tramitação da LOA no interior do Legislativo................................................. 41

Figura 4: Principais alterações sobre a participação do Legislativo no orçamento durante a ANC. 45

Figura 5: Resumo das principais alterações aprovadas pelas Resoluções do Congresso

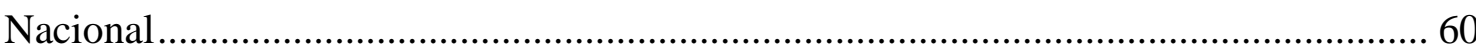

Figura 6: Destino que as Emendas Individuais devem seguir na elaboração da Lei

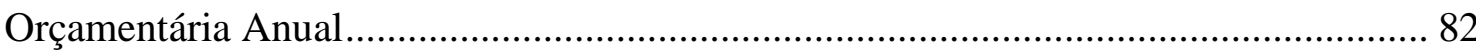




\section{LISTA DE GRÁFICOS}

Gráfico 1: Porcentagem de recursos em despesas obrigatórias da União 31

Gráfico 2: Porcentagem de recursos aprovados por Grupo de Despesa (GND) em relação

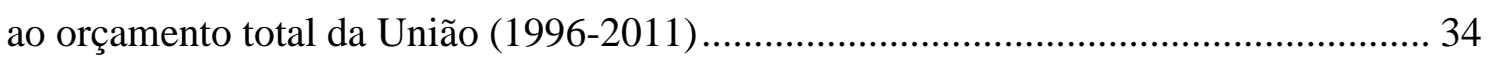

Gráfico 3: Média da disciplina partidária por ano (1995-2010) .................................... 71

Gráfico 4: Disciplina partidária em relação ao líder do governo ................................... 74

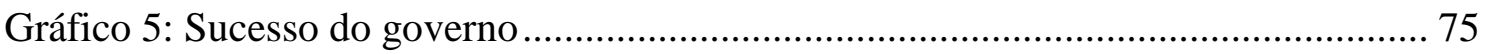

Gráfico 6: Distribuição da disciplina partidária média em relação ao governo e a taxa de execução média das emendas por parlamentar (1995-2010) .......................................... 79

Gráfico 7: Quantidade de Deputados Federais que apresentam emendas por ano (1995-

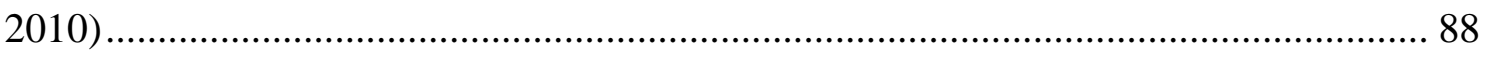

Gráfico 8: Quantidade de Ministérios que recebem emendas por ano (1995-2010) ...... 89 Gráfico 9: Média da porcentagem de recursos que os parlamentares destinaram aos

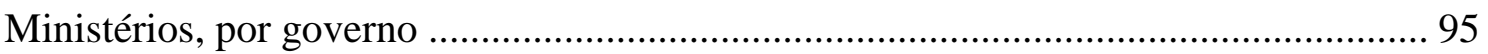

Gráfico 10: Distribuição da parcela de recursos para os Ministérios de acordo com os

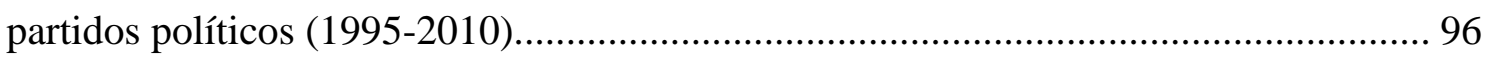

Gráfico 11: Média de recursos que os parlamentares destinaram para um único Ministério, por governo. 99

Gráfico 12: Distribuição da parcela de recursos para os Ministérios de acordo com os partidos políticos "Não Governo" (1995-2010)

Gráfico 13: Destino das emendas individuais dos parlamentares que não pertencem a base do governo de acordo com os Ministérios que mais detém recursos em Investimentos (1995-2002)

Gráfico 14: Destino das emendas individuais dos parlamentares que não pertencem a base do governo de acordo com os Ministérios que mais detém recursos em Investimentos (2003 -2010) 104

Gráfico 15: Recursos emendas executadas recebidas pelos parlamentares da coalizão e pelos parlamentares "Não Governo" (1995-2010) 108

Gráfico 16: Média dos recursos executados em emendas individuais de acordo com o controle da pasta ministerial e os parlamentares (1995-2010) 110

Gráfico 17: Média dos recursos executados em emendas individuais de acordo com os parlamentares que pertencem ao mesmo partido do Ministro (1995-2010). 


\section{LISTA DE TABELAS}

Tabela 1: Quantidade de Créditos Adicionais por Governo (1995-2014)

33

Tabela 2: Quantidade e limite de valores das emendas individuais orçamentárias (19962011)

Tabela 3: Quantidade de combinações entre deputados federais e destino das emendas para Ministérios 
LISTA DE SIGLAS

\begin{tabular}{ll} 
ANC & Assembleia Nacional Constituinte \\
CMO & Comissão Mista de Orçamento \\
CPI & Comissão Parlamentar de Inquérito \\
DEM & Democratas \\
GND & Grupo Natureza da Despesa \\
LDO & Lei de Diretrizes Orçamentárias \\
LOA & Lei Orçamentária Anual \\
MPV & Medida Provisória \\
PCB & Partido Comunista Brasileiro \\
PCdoB & Partido Comunista do Brasil \\
PDS & Partido Democrático Social \\
PDT & Partido Democrático Trabalhista \\
PEC & Proposta de Emenda à Constituição \\
PFL & Partido da Frente Liberal \\
PL & Partido Liberal \\
PMDB & Partido do Movimento Democrático Brasileiro \\
PMR & Partido Municipalista Renovador \\
PP & Partido Progressista \\
PPA & Plano Plurianual \\
PPB & Partido Progressista Brasileiro \\
PPS & Partido Popular Socialista \\
PR & Partido da Republica \\
PRB & Partido Republicano Brasileiro \\
PROS & Partido Republicano da Ordem Social \\
PSB & Partido Socialista Brasileiro \\
PSD & Partido Social Democrático \\
PSDB & Partido da Social Democracia Brasileira \\
PT & Partido dos Trabalhadores \\
PTB & Partido Trabalhista Brasileiro \\
PV & Partido Verde \\
& \\
\hline
\end{tabular}




\section{SUMÁRIO}

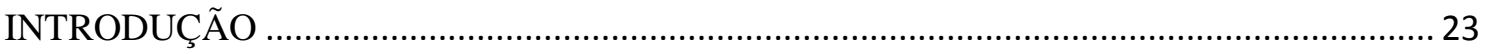

CAPÍTULO 1- A matéria-prima das políticas: o orçamento da união ......................................... 27

1. Das responsabilidades do Executivo na elaboração do orçamento da União ........................ 27

2. O papel do Legislativo na elaboração do Orçamento............................................................. 35

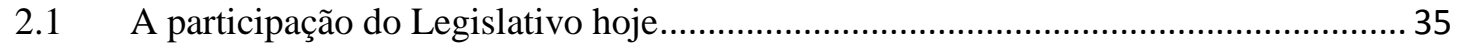

2.1 A evolução no tempo: ampliação e restrições da participação do Legislativo .............. 42

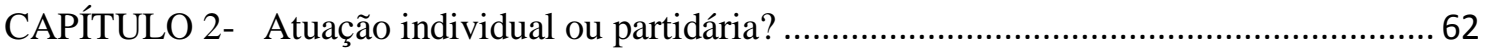

1. Ação coletiva e atuação parlamentar: modelos explicação .................................................. 63

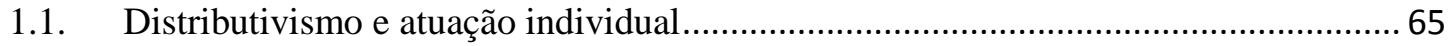

1.2. Partidos políticos como agentes estruturantes da arena decisória .................................67 67

2. O debate e evidências da atuação dos parlamentares no Brasil.............................................. 70

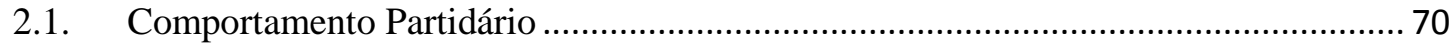

2.2 Emendas individuais orçamentárias: a evidência contrária à coordenação partidária no

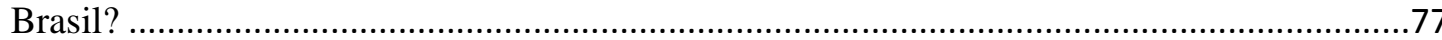

3. Construindo a coordenação partidária no orçamento .......................................................... 81

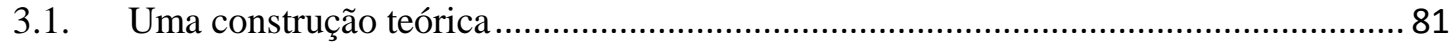

3.2 Uma construção empírica: hipóteses e universo de análise.......................................... 85

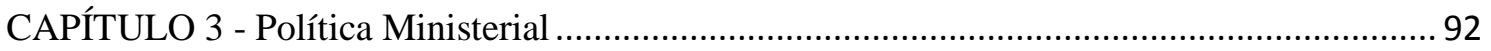

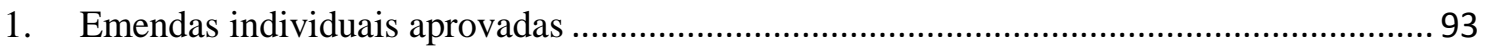

1.1 Comportamento partidário dos parlamentares da coalizão .......................................... 94

1.2 Comportamento partidário dos parlamentares fora do governo .................................. 98

1.3 Considerações parciais acerca das evidências apresentadas sobre as emendas

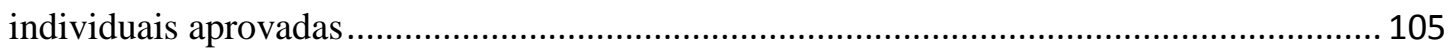

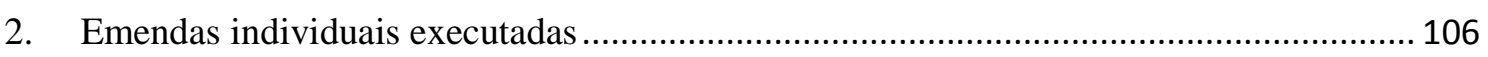

2.1 Ser governo e não ser governo faz diferença ......................................................... 107

2.2 Mais do que ser governo: o partido importa.......................................................... 109

2.3 Considerações parciais acerca das evidências sobre a alocação dos recursos das

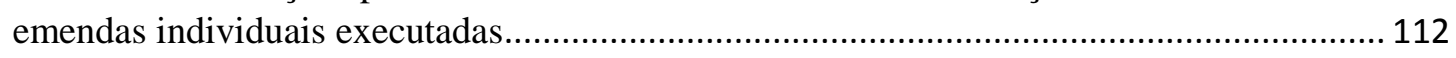

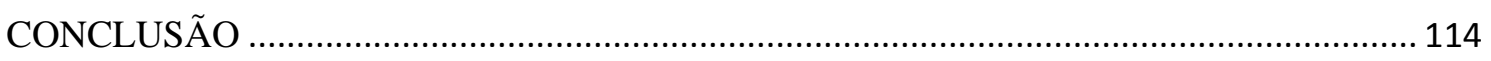

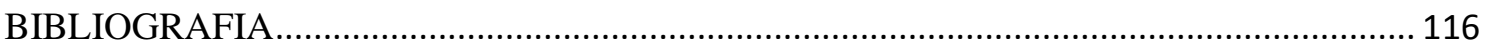




\section{INTRODUÇÃO}

No início do mês de dezembro de 2013, o jornal Folha de São Paulo trazia em seu caderno a seguinte manchete: "Governo reduz verba para emendas de parlamentares: medida pode azedar a relação do Palácio do Planalto com os congressistas ${ }^{2}$ ". Notícias como essa, que atrelam as emendas individuais orçamentárias ao funcionamento do presidencialismo de coalizão brasileiro, são recorrentes e deixam transparecer não só a opinião e descrença do público, como também a opinião de especialistas quando o assunto é a relação entre o Legislativo e o Executivo.

A principal ideia por de trás dessas informações comumente veiculadas na mídia é a de que os partidos brasileiros não teriam força ou não seriam fortes o suficiente para disciplinar seus parlamentares. O diagnóstico, no entanto, não é dado sem ter antes uma causa. A adoção do sistema de representação proporcional de lista aberta, bem como do sistema presidencialista, é que criariam, juntos, os incentivos para uma atuação mais individual do parlamentar. Motivados, sobretudo, pelo desejo de alcançar o tão sonhado sucesso eleitoral, os parlamentares brasileiros não enxergariam nos seus respectivos partidos, bem como no apoio dado ao Executivo, as ferramentas necessárias para conquistar tais objetivos.

Por mais que os estudos datados da década de 90, pós-redemocratização, tenham lançado luz e comprovado empiricamente como os trabalhos no interior do Congresso Brasileiro só são de fato realizados dada a capacidade que os partidos políticos principalmente sob a figura dos líderes partidários - têm de organizar todo o processo legislativo (FIGUEIREDO; LIMONGI, 1999), prevalece o diagnóstico segundo o qual os parlamentares brasileiros atuariam pensando e tendo em vista apenas os seus interesses individuais.

As altas taxas de disciplina partidária, bem como as altas taxas de sucesso e dominância do Executivo não são tomadas como evidências suficientes para contestar tal visão. Estes dados indicariam tão somente que o Executivo é munido de ferramentas capazes de induzir os parlamentares à cooperação. A força centrípeta do Executivo seria mais forte que a centrífuga posta em marcha pela legislação eleitoral. O Executivo e os líderes partidários seriam capazes de moderar a força desagregadora do individualismo. Nestes

\footnotetext{
${ }^{2}$ A notícia foi publicada em 10/12/2013 e pode ser visualizada através do seguinte endereço eletrônico: http://www1.folha.uol.com.br/poder/2013/12/1383281-governo-reduz-verba-para-emendas-deparlamentares.shtml
} 
termos, os partidos permanecem em segundo plano, se é que venham a figurar no quadro. Certamente, os partidos não são vistos como capazes de assumir o papel de agentes responsáveis por formular e zelar pelos acordos entre o próprio Executivo e Legislativo e, muito menos, entre os próprios parlamentares.

Por isto mesmo, em função da sobrevivência desta visão arraigada, convencionouse valorizar as emendas individuais orçamentárias como evidências do comportamento individualista dos parlamentares no interior do Congresso brasileiro. Essas emendas seriam uma, dentre as outras ferramentas que o Executivo faria uso para induzir os parlamentares à cooperação.

Sob a perspectiva do parlamentar, seu interesse em elaborar uma emenda estaria fortemente atrelado a uma busca por atender as demandas de seu eleitorado e, assim, garantir com essa ação a manutenção de seu cargo. As emendas individuais seriam a oportunidade perfeita dos políticos "premiarem" seus redutos eleitorais e, dessa forma, alcançarem a reeleição (AMES, 2003; PEREIRA; RENNO, 2001, 2007). Por outro lado, sob a ótica do Executivo, dado que o Congresso seria composto por políticos individualistas e indisciplinados em relação a seus respectivos partidos políticos, a liberação dos recursos das emendas individuais seria essencial para a obtenção do apoio dos parlamentares para a aprovação de uma agenda de políticas (AMORIM NETO; SANTOS, 2003; PEREIRA; MUELLER, 2002, 2003; SANTOS, 1997).

A escolha das emendas individuais como indício dessa atuação individualista dos parlamentares não é estranha. O processo de elaboração e proposição das emendas individuais orçamentárias seria, ou ao menos parece ser, um dos momentos em que o parlamentar teria maiores oportunidades para agir individualmente, ou seja, independente do seu partido e da necessidade de pertencer a um. Se para ocupar o cargo em uma comissão, escolher projetos que serão votados, pedir urgência na tramitação dos projetos, dentre outras atividades a serem realizadas no interior do Congresso, o parlamentar necessariamente precisa pertencer a um partido político, o mesmo não acontece no momento da apresentação de emendas orçamentárias, em que cada parlamentar pode sozinho escolher de forma livre e, o mais importante, de acordo com o seu interesse as políticas e municípios que serão agraciados com os recursos que ele tem o direito de remanejar no interior da peça orçamentária.

A decisão, portanto, sobre o que fazer com os recursos que cada parlamentar tem disponível cabe só aos próprios. O partido político, mesmo que representado pela figura do líder partidário, não detém nenhum poder institucional capaz de alterar ou determinar 
essa decisão. Contudo, embora essas afirmações sejam verdadeiras, isso não significa que o partido não influencie e que não possa influenciar essa decisão. E é justamente sobre esse ponto que o presente trabalho pretende se debruçar.

Seguindo na contramão das constatações expostas acima de que os parlamentares atuariam de forma individualizada, esse trabalho tem como objetivo principal o de mostrar como até no momento da participação do parlamentar no orçamento o partido se faz presente e é capaz de coordenar a ação dos seus parlamentares em prol das políticas e do interesse coletivo do partido. Assim como acontece com os demais trabalhos legislativos no interior do Congresso brasileiro, os parlamentares sabem e reconhecem que a melhor chance que eles têm de atingirem seus objetivos na arena orçamentária é também a de agir por meio dos seus respectivos partidos políticos.

Sendo assim, analisando os ministérios de destino dos recursos das emendas individuais orçamentárias, mostrarei que (i) os parlamentares pertencentes à coalizão escolhem destinar a maior parcela de seus recursos para os ministérios controlados pelos seus respectivos partidos; (ii) os parlamentares que não pertencem à coalizão de governo escolhem destinar a maioria dos seus recursos também para ministérios específicos e (iii) os partidos à frente das pastas ministeriais buscam beneficiar os membros dos seus próprios partidos na execução das emendas. Ambas as estratégias adotadas, se comprovadas, trariam a evidência não só de que, quando alteram o orçamento, os parlamentares atuam de acordo com seus partidos políticos, como também que os parlamentares da coalizão apoiam as políticas formuladas por seus respectivos partidos políticos.

No que segue, para atingir os as finalidades aqui propostas, o trabalho se encontra dividido em três capítulos. O objetivo do primeiro capítulo é apresentar ao leitor as regras do funcionamento e da participação do Executivo e do Legislativo na elaboração do Orçamento da União. O foco das análises desse capítulo recairá no entendimento de como a participação dos parlamentares foi sendo moldada e restringida ao longo do tempo até chegar nas atuais regras de atuação. Será possível ter conhecimento de todas as principais discussões que envolveram a adoção das resoluções do Congresso Nacional, responsáveis por definir a participação dos parlamentares na alteração da peça orçamentária, sobretudo quanto à proposição das famosas emendas individuais orçamentárias.

No segundo capítulo, estão expostos os principais argumentos e estudos acerca do comportamento dos parlamentares quando inseridos em contextos de tomada de decisões coletivas. Também serão apresentados os principais estudos que tratam especificamente 
do comportamento dos parlamentares brasileiros na arena legislativa e os principais argumentos mobilizados para explicar a relação entre um comportamento mais voltado para o indivíduo e o uso das emendas individuais orçamentárias. Esse capítulo também expõe e se propõe a explicar o universo das análises e as hipóteses levantadas acerca do comportamento dos atores políticos no momento de alteração da peça orçamentária.

Por fim, o terceiro e último capítulo traz as análises dos dados. Nessa etapa do trabalho será possível observar o comportamento dos parlamentares situados tanto dentro, quanto fora da base aliada do governo e de seus respectivos partidos políticos em dois momentos principais: no momento de proposição das emendas individuais orçamentárias e no momento da execução dessas emendas. O objetivo será o que verificar empiricamente se há evidências ou não para argumentar que os partidos políticos coordenam a atuação dos parlamentares até mesmo nessa esfera de atuação. 


\section{CAPÍTULO 1- A matéria-prima das políticas: o orçamento da união}

\section{Das responsabilidades do Executivo na elaboração do orçamento da União}

A redemocratização no Brasil, ainda em 1988, trouxe importantes mudanças para o sistema político brasileiro. No que tange a arena orçamentária, não só foi mantido o poder Legislativo do presidente de iniciar legislação nessa área e de controlar importantes etapas do processo, mas mais importante do que isso: foi devolvido ao Congresso a possiblidade de interferir no Orçamento.

De acordo com o artigo 61, inciso 1 da Constituição a elaboração do orçamento, que envolve a formulação de um Plano Plurianual (PPA), das Leis anuais de Diretrizes Orçamentárias (LDO), bem como das Leis Orçamentárias Anuais (LOA), é uma dentre as prerrogativas legislativas exclusivas do Presidente da República. Contudo, um fator importante e esquecido por muitos é que a mesma Constituição que deu ao presidente tamanho poder legislativo, também retomou o poder de apreciação dessa matéria pelos membros do Legislativo. Assim, mesmo que o presidente detenha o direito exclusivo de iniciar matérias na área orçamentária, o conteúdo do que está sendo proposto tem que passar pela aprovação do Congresso Nacional (GIACOMONI, 2012).

O orçamento brasileiro é composto principalmente por três etapas. A primeira delas é a formulação de um Plano Plurianual (PPA) para o período de quatro anos. Neste plano o Executivo deve estabelecer os objetivos, diretrizes e metas previstos para os quatro anos de governo. Esse plano é formulado através das necessidades de gastos que cada Ministério apresenta a Secretaria de Orçamento Fiscal (SOF) integrada ao Ministério do Planejamento Orçamento e Gestão (MPOG) que fica responsável pela formulação do PPA. É válido ressaltar que é de responsabilidade de cada Ministério e Ministro apresentar as áreas de gastos e políticas - traduzidas em programas de governo - que serão prioritárias, durante os quatro anos de governo. Após esse processo de formulação, o Executivo obrigatoriamente deve encaminhar a proposta do PPA para o Congresso Nacional que somente possui a competência de realizar emendas de texto à proposta, sem poder realizar nenhuma nova proposição no quesito de prioridade e destino das verbas da União.

A segunda etapa do processo orçamentário e também a que mais aproxima os gastos da realidade econômica e financeira do país é a formulação anual de uma Lei de Diretrizes Orçamentárias (LDO). Como o próprio nome já diz, essa lei compreende as 
diretrizes, metas e prioridades da administração federal, incluindo as despesas para o ano seguinte. A definição das prioridades é de competência do Ministério do Planejamento e do Ministério da Fazenda - responsável por controlar as finanças do país - que estabelecem e analisam juntos quais serão as despesas para o exercício financeiro subsequente. Também é estabelecido na LDO as obras/políticas que serão passíveis de receber acréscimo de gastos dos parlamentares, bem como o montante de recursos que estes terão disponível para remanejar no orçamento. Novamente, após sua elaboração, o Executivo deve remeter a proposta da LDO ao Legislativo que, da mesma forma que no PPA, somente pode realizar emendas de texto e aprovar/rejeitar o projeto.

Por fim, tendo com base na LDO a Lei Orçamentária Anual (LOA) deve ser elaborada. A LOA é considerada, entre as três etapas da elaboração orçamentária, a lei orçamentária mais importante. É ela que determinará de fato os gastos do governo, em cada área específica, durante 12 meses. Assim como no PPA, é de responsabilidade de cada Ministério elaborar sua proposta de gastos, estabelecendo criteriosamente quais serão os recursos necessários para cada programa e políticas sob sua gestão. Também fica a cargo de cada órgão encaminhar suas propostas para a SOF que se encarrega de organizar todas as informações em uma única proposta que segue para a aprovação do Presidente e depois para a análise do Poder Legislativo.

Diferente do PPA e da LDO, o Congresso Nacional, além de realizar emendas de texto ao projeto inicial da LOA, também ganha o poder de adicionar e cancelar recursos que já tenham sido definidos anteriormente, ou seja, o Legislativo não pode propor uma nova obra/política na proposta, contudo, pode adicionar receitas ou cortar gastos já existentes. Para além disso, no caso da adição de receitas, os parlamentares somente o podem realizar de acordo com as exigências e prioridades estabelecidas pela LDO. Assim, não é qualquer política ou obra da LOA que o parlamentar pode alocar seu dinheiro. Ele deve seguir o que foi definido na LDO referente as proposições que podem ser se sua competência. Essa questão será tratada com mais detalhes adiante.

Por ora, a Figura 1 resume o processo de elaboração das três etapas do processo orçamentário brasileiro, bem como seus respectivos prazos para aprovação. Vale, aqui, destacar a autonomia que os Ministérios detêm na formulação das políticas que serão inseridas tanto no PPA, quanto na LOA. 


\section{Figura 1: Processo de Elaboração das Principais Leis Orçamentárias}

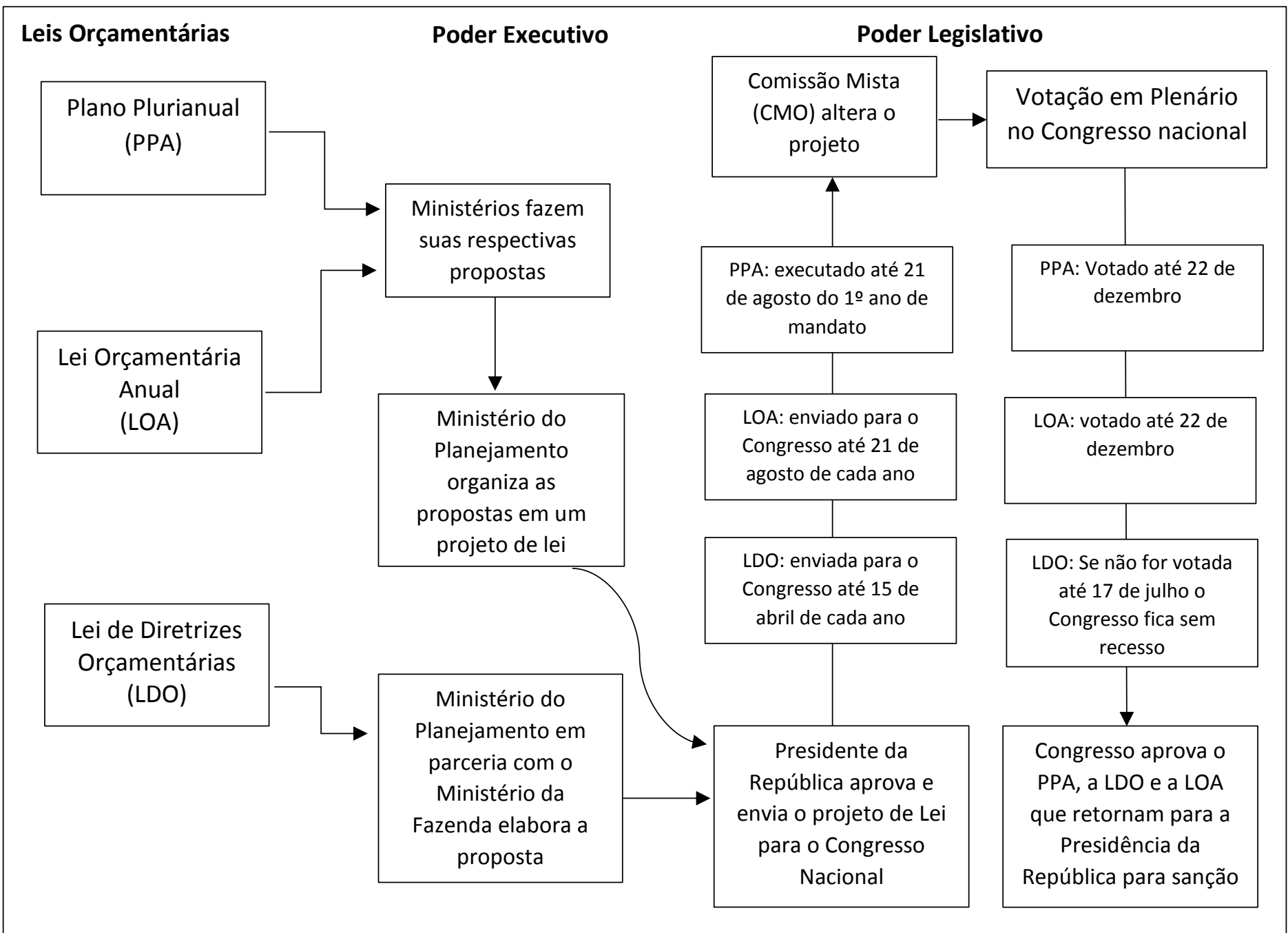

Fonte: Elaboração própria de acordo com as definições da Câmara dos Deputados e do Senado Federal

Para além da prerrogativa de elaborar o orçamento, o Executivo não tem o dever e nem é obrigado a executar as despesas tais como elas foram aprovadas na $\mathrm{LOA}^{3}$. Ou

\footnotetext{
${ }^{3}$ O Projeto da Emenda Constitucional (PEC) 358/2013, também conhecida como a PEC do "Orçamento Impositivo" adotou importantes modificações quanto a apresentação e execução das emendas individuais orçamentárias. De acordo com a PEC o Governo Federal deve obrigatoriamente executar as emendas de parlamentares ao orçamento da União no valor limite de $1,2 \%$ da receita corrente liquida (aquilo que a União arrecada menos o que repassa a estados e municípios) - o que equivale a cerca de $\mathrm{R} \$ 8,7$ bilhões atualmente - entre outros requisitos, como a obrigatoriedade de uma proporcionalidade no contingenciamento do Executivo em suas contas. Ou seja, caso o governo se veja obrigado a diminuir suas despesas, ele só poderá cortar a verba para as emendas parlamentares se a mesma proporção do resto do orçamento for cortada. Do lado dos parlamentares a PEC 358/2013 também exige que 50\% do valor disponível em emedas individuais seja destinado para o Ministério da Saúde. Isso significa afirmar que do total que o parlamentar tem disponível para apresentar em emendas individuais orçamentárias, $50 \%$ obrigatoriamente devem ser alocadas na área de saúde. Só restando 50\% para o parlamentar alocar em outras áreas definidas pela LDO. Como mencionado, só trabalharei os dados até o ano de 2011 e por isso não irei me deter as modificações introduzidas por essa PEC.
} 
seja, o orçamento no Brasil é autorizativo. É o Executivo quem detém a última palavra sobre como e quais gastos serão executados ao longo do ano. Fica a cargo de cada Ministério e de suas respectivas secretarias - também conhecidas como Unidades Orçamentárias - definir as obras que de fato serão executadas.

A ressalva, no entanto, existe quanto aos gastos que a própria Constituição e legislação brasileira estipulam que devam ser obrigatórios. As despesas como pagamento de aposentadorias, pensões, salários de servidores, seguro desemprego, benefícios assistenciais, transferências para estados e municípios e despesas fixas na área de educação e saúde ${ }^{4}$, entre outras, o que reduz significativamente a autonomia que o Executivo detém sobre a execução dos gastos. O Gráfico 1 abaixo apresenta, entre os anos de 1996 e 2011, a porcentagem em relação ao total do orçamento em despesas obrigatórias e despesas não obrigatórias que o Executivo deteve sobre os valores aprovados e, de fato, executados.

\footnotetext{
${ }^{4}$ A Constituição brasileira no artigo 212 determina que a União deve obrigatoriamente gastar $18 \%$ da arrecadação de impostos com políticas de educação. Já nos artigos 165, 166 e 198 fica definido que é de responsabilidade também da União gastar 13,2\% dos impostos com políticas na área de saúde.
} 


\section{Gráfico 15: Porcentagem de recursos em despesas obrigatórias da União}

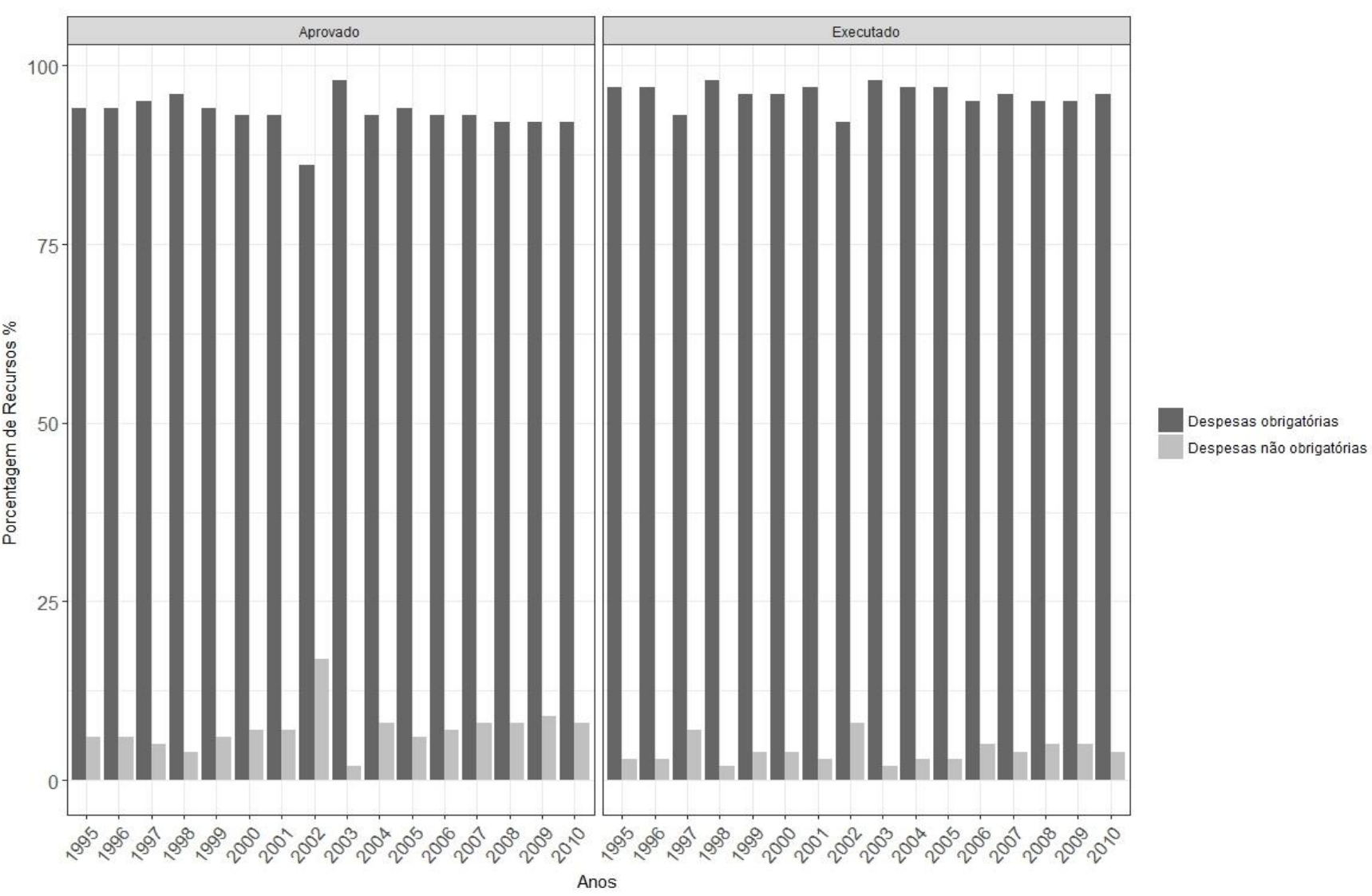

Fonte: Banco de Dados do Orçamento da União do Cebrap e SIGA Brasil.

Destaca-se que em todos os anos a parcela de recursos com despesas obrigatórias passa dos $90 \%$, ou seja, de fato apesar de o orçamento brasileiro ser autorizativo, o Executivo detém uma parcela bem restrita do orçamento para remanejar e executar à sua vontade e revelia. De acordo com os dados apresentados acima, enquanto a média de recursos aprovados que a União pode decidir livremente como gastar não passa dos 7\%, a mesma média para os valores executados não passa dos $4 \%$.

No entanto, ainda que a parcela de recursos que o Executivo detém com despesas não obrigatórias seja pequena, atribuir a característica autorizativa ao orçamento significa não só que o Presidente pode ou não executar gastos, significa também deter o poder de alterar a lei orçamentária vigente seja mediante a alocação/realocação de verbas em gastos anteriormente previstos ou na alocação de verbas em projetos não previstos, anteriormente na LOA. Essas alocações/remanejamentos que o presidente pode realizar

\footnotetext{
${ }^{5}$ Os gastos com refinanciamento da dívida não foram considerados, uma vez que os valores com essa rubrica diminuíram significativamente em 2004, quando o Presidente Luiz Inácio Lula da Silva saldou parcela considerável da dívida externa brasileira.
} 
durante a execução da lei orçamentária são conhecidos como créditos adicionais e eles são, essencialmente, de três tipos: (i) suplementares; (ii) especiais e (iii) extraordinários.

O primeiro deles, os suplementares, servem para reforçar dotações orçamentárias já existentes no caso de elas se apresentarem insuficientes para a realização de alguma obra. A receita para esses créditos deve obrigatoriamente ter como fonte $\mathrm{o}$ cancelamento/remanejamento de dotações já existentes na LOA. Os créditos especiais são para a alocação de receita em projetos e obras não previstos anteriormente pela LOA, sendo que sua fonte de origem deve ser proveniente de superávit ou da reserva de contingência ${ }^{6}$.

Por fim, têm-se os créditos extraordinários que são destinados para o atendimento de situações urgentes e imprevisíveis como guerra, calamidade pública ou perturbação da paz. Sua fonte de receitas também é proveniente da reserva de contingência ou do cancelamento/remanejamento de dotações já definidas. Destaca-se que enquanto os créditos suplementares e especiais ${ }^{7}$ necessitam de autorização prévia do Legislativo para serem liberados, os créditos extraordinários podem ser atendidos por meio da apresentação de medidas provisórias (MPV).

A Tabela 1 abaixo apresenta as informações das quantidades de créditos adicionais que foram apresentados e aprovados entre os anos de 1995 e 2014, período este que cobre os governos do presidente Fernando Henrique Cardoso (FHC), do presidente Luiz Inácio Lula da Silva (LULA) e o primeiro mandato da presidente Dilma Rousseff. Como será possível observar, todos os presidentes aqui analisados fazem o uso de tais prerrogativas.

\footnotetext{
${ }^{6}$ A reserva de contingência fica definida como sendo: "dotação constante da lei orçamentária, sem destinação específica nem vinculação a qualquer órgão, cuja finalidade principal é servir de fonte de cancelamento para a abertura de créditos adicionais, ao longo do exercício. De acordo com as edições mais recentes da LDO, devem ser constituídas reservas de contingência vinculadas aos orçamentos fiscal e da seguridade social, em valores da ordem de três por cento, respectivamente, da receita global de impostos da receita de contribuições sociais.". Para mais informações acessar: http://www.orcamentofederal.gov.br/glossario-1/reserva-de-contingencia

${ }^{7}$ Constituição Federal: art. 167. "São vedados: [...] V- a abertura de crédito suplementar ou especial sem prévia autorização legislativa e sem indicação dos recursos correspondentes."

Lei $\mathrm{n}^{\circ}$ 4.320/64: art.42. "Os créditos suplementares e especiais serão autorizados por lei e abertos por decreto executivo."
} 
Tabela 1: Quantidade de Créditos Adicionais por Governo (1995-2014)

\begin{tabular}{|l|c|c|c|c|c|c|}
\hline & \multicolumn{2}{|c|}{ Crédito Suplementar } & \multicolumn{2}{c|}{ Crédito Especial } & \multicolumn{2}{c|}{ Créditos Extraordinários } \\
\cline { 2 - 7 } & Apresentados & Aprovados & Apresentados & Aprovados & Apresentados & Aprovados \\
\hline FHC I & 246 & 244 & 114 & 110 & 14 & 14 \\
FHC II & 302 & 284 & 123 & 111 & 43 & 41 \\
LULA I & 165 & 131 & 84 & 78 & 53 & 3 \\
LULA II & 189 & 171 & 150 & 116 & 38 & 6 \\
DILMA I & 98 & 80 & 77 & 58 & 28 & 20 \\
\hline
\end{tabular}

Fonte: Banco de Dados do Legislativo do Cebrap.

Ao longo do ano vigente de execução da LOA, o Presidente conta não só com a ferramenta dos créditos adicionais, mas também com a possibilidade editar decretos de contingenciamento ${ }^{8}$. Esses decretos consistem no adiamento ou na não execução de parte das despesas previstas e programadas na LOA. Geralmente, o Governo Federal emite esses decretos limitando os valores, anteriormente autorizados na LOA, relativos às despesas discricionárias ou que não exigem obrigatoriedade para serem executadas, o que significa que a maioria dos cortes realizados pelo governo são realizados sobre a classificação orçamentária tida como Investimentos.

O orçamento brasileiro é todo pensado e organizado em cima de classificações, como a citada acima. Uma dessas classificações é a por Grupos de Natureza da Despesa (GND). Nesse arranjo é possível não só diferenciar os tipos de gastos que o governo possui, bem como identificar aqueles que são os mais importantes para a implementação de políticas: o grupo de investimentos. Ao todo a classificação por GND implica em seis divisões, sendo elas: 1. Pessoal e Encargos sociais; 2. Juros e Encargos da Dívida; 3. Outras Despesas Correntes; 4. Investimentos; 5. Inversões Financeiras e 6. Amortização da Dívida9 .

Para a finalidade desse trabalho, a área de Investimentos é a de maior interesse, pois compreende a matéria-prima para que novas políticas sejam de fato concretizadas. As demais classificações, são as responsáveis por garantir o funcionamento da máquina pública, sendo que dentre essas a área de Despesas Correntes também deve receber determinada atenção, uma vez que os gastos nessa rubrica representam os gastos com a

\footnotetext{
${ }^{8} \mathrm{O}$ Decreto de Contingenciamento apresenta como anexos limites orçamentários para a movimentação e o empenho de despesas, bem como limites financeiros que impedem pagamento de despesas empenhadas e inscritas em restos a pagar, inclusive de anos anteriores. O poder regulamentar do Decreto de Contingenciamento obedece ao disposto nos artigos $8^{\circ}$ e $9^{\circ}$ da Lei de Responsabilidade Fiscal (LRF) e da Lei de Diretrizes Orçamentárias (LDO).

${ }^{9}$ Para mais informações a respeito do que se trata cada um dos respectivos GNDs ver Giacomoni(2012, p. 113 e 114)
} 
manutenção e a realização das políticas já existentes. Dado que este trabalho parte do pressuposto que os partidos são atores interessados em políticas, será sobre esses dois grupos que a presente pesquisa será realizada. Por ora, limito-me a explanações mais gerais.

O Gráfico 2 discrimina as dotações de acordo com os GNDs. Destaca-se, justamente, o GND de Investimentos que possui a uma das menores parcelas de recursos e o GND de Despesas Correntes que, na contramão, apresenta a segunda maior parcela de recursos. Na média, o grupo de despesas de Investimento corresponde somente a $2 \%$ do montante total aprovado para a LOA, enquanto Outras Despesas Correntes representa, na média, 24\% do montante total. Outros grupos como Amortização da Dívida e recentemente Inversões Financeiras e Pessoal e Encargos Sociais são os responsáveis não só por abraçar a maior parcela de recursos, bem como por manter a máquina pública em funcionamento e "engessar", como vimos anteriormente, os gastos do Executivo.

\section{Gráfico 2: Porcentagem de recursos aprovados por Grupo de Despesa (GND) em relação ao orçamento total da União (1996-2011)}

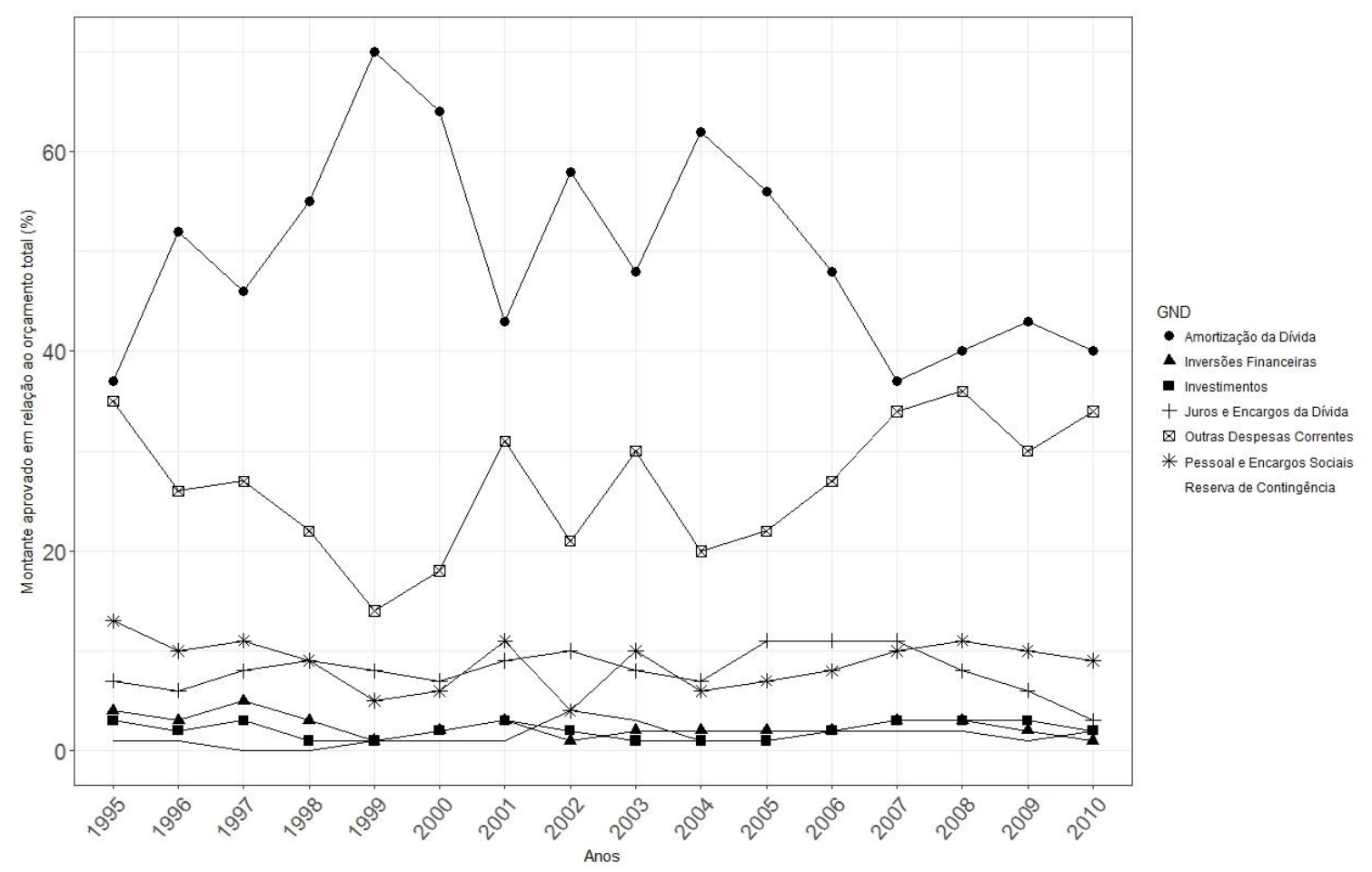

Fonte: Banco de Dados do Orçamento da União do Cebrap e SIGA Brasil.

Para fins dessa dissertação, aspectos importantes a respeito da elaboração do orçamento por parte do Executivo já foram aqui abordados. Dentre as explicações expostas acima, merece atenção: a autonomia de cada Ministério em elaborar sua proposta 
orçamentária; o poder autorizativo do presidente em executar e alterar os gastos, bem como as ferramentas de que ele dispõe para fazer isso com o apoio do Legislativo créditos adicionais e os decretos de contingenciamento - e, por fim, o montante de recursos disponível, de fato, para que a agenda de políticas do Executivo se concretize. Falta agora trazer um novo elemento para dentro do processo de elaboração do orçamento: o Legislativo.

\section{O papel do Legislativo na elaboração do Orçamento}

Desde a Constituição de 1988, uma série de mudanças foram introduzidas no sistema político brasileiro e, como dito anteriormente, para além da carta de 88 ter atribuído importantes poderes legislativos ao Executivo, ela também devolveu uma importante ferramenta aos membros do Legislativo: a possibilidade de apreciar, controlar e emendar o orçamento. Ainda que os parlamentares não possuam o direito de iniciar legislação nessa área, possuem o direito, definido pela Constituição, de alterar a proposta inicial desses projetos encaminhados pela Presidência da República.

Após a promulgação da Constituição de 88 , teve início uma sequência de lutas e processos para aprimorar e melhorar cada vez mais a participação do Legislativo na peça orçamentária. As regras estabelecidas hoje nesse processo carregam com elas não só episódios históricos, bem como intensos debates e mudanças que resultaram, ao longo dessa trajetória, em uma participação cada vez mais ativa, coletiva e transparente do Legislativo na área orçamentária. Sendo assim, esta seção tem por objetivo apresentar, de forma resumida, como ocorre a participação do Legislativo nos dias de hoje no orçamento e como essa mesma trajetória foi estabelecida até aqui.

\subsection{A participação do Legislativo hoje}

No artigo 166, a Constituição brasileira define de forma clara e objetiva qual a responsabilidade dos membros do Legislativo na apreciação do orçamento. Para além de estabelecer que o PPA, a LDO, a LOA e os créditos adicionais devem ser apreciados pelo Congresso Nacional, esse artigo também determina que as emendas apresentadas aos projetos de lei dessa área devem, obrigatoriamente, ser apresentadas e analisadas por uma 
Comissão Mista ${ }^{10}$ instaurada especialmente para processos dessa origem. Cabe, portanto, a Comissão Mista do Orçamento (CMO) julgar se as emendas seguem ou não os dois principais critérios estabelecidos no artigo 166, parágrafo terceiro, inciso I e II:

$\S 3^{\circ}$ As emendas ao projeto de lei do orçamento anual ou aos projetos que o modifiquem somente podem ser aprovadas caso:

I - sejam compatíveis com o plano plurianual e com a lei de diretrizes orçamentárias;

II - indiquem os recursos necessários, admitidos apenas os provenientes de anulação de despesa, excluídas as que incidam sobre: a) dotações para pessoal e seus encargos; b) serviço da dívida; c) transferências tributárias constitucionais para Estados, Municípios e Distrito Federal;

(Constituição Federal de 1988, artigo 166.)

A depender da natureza do projeto orçamentário em tramitação, o parlamentar pode apresentar três tipos de emendas: (i) as te texto que são responsáveis por alterar o texto do projeto de lei ou seus quadros e tabelas. Tais emendas são aplicáveis tanto na apreciação do PPA, da LDO, da LOA quanto nos créditos adicionais; (ii) as emendas de receita - também conhecidas como emendas de correção - que alteram a estimativa da receita e que só são cabíveis na LDO, na LOA e nos créditos adicionais. Por último, temse as (iii) emendas de despesa que acrescentam valores às dotações do projeto de lei orçamentária da LOA e aos créditos adicionais, bem como cancelam dotações desses projetos.

Dentre esses três tipos, as emendas de despesa são as que de fato permitem que os parlamentares, por exemplo, tenham a oportunidade de agregar suas preferências por determinadas políticas. São essas emendas que permitem que eles aloquem dotações específicas e de seu interesse em programações anteriormente definidas como prioritárias pelo Ministério da Fazenda e do Planejamento na LDO, bem como pelos demais Ministérios na LOA.

Atentando exclusivamente para as características da tramitação do projeto da Lei Orçamentária Anual (LOA), a proposta é encaminhada pela Presidência da República e chega diretamente às mãos do relator geral da CMO. O relator geral, por sua vez, fica responsável por elaborar um parecer preliminar que deve, obrigatoriamente, conter não só uma apreciação das despesas disponíveis para serem realocadas pelos membros do

\footnotetext{
${ }^{10}$ Uma comissão Mista é aquela em que a formação é dada tanto por Deputados quanto por Senadores e tem como objetivo tratar de questões relacionadas ao Congresso Nacional. Essas comissões podem ser temporárias, como as de inquérito, ou permanentes como a do Mercosul e a Comissão Mista do Orçamento (CMO).
} 
Legislativo, como também o montante das verbas disponíveis para cada área temática do orçamento e para a aprovação das emendas de despesa.

Após essa etapa, a matéria orçamentária é distribuída, em conjunto com seu parecer preliminar, para os relatores setoriais. Ao todo existem dez relatorias setoriais que são divididas de acordo com as áreas temáticas do orçamento e Ministérios afins. A Figura 2 abaixo apresenta essas dez áreas temáticas e os respectivos Ministérios a elas correlacionados:

Figura 2: Áreas temáticas e Ministérios afins

\begin{tabular}{|c|c|}
\hline Áreas Temáticas & Ministérios Relacionados \\
\hline Infraestrutura & $\begin{array}{l}\text { - Ministério de Minas e Energia } \\
\text { - Ministério dos Transportes } \\
\text { - Ministério das Comunicações }\end{array}$ \\
\hline Saúde & - Ministério da Saúde \\
\hline Integração Nacional e Meio Ambiente & $\begin{array}{l}\text { - Ministério da Integração Nacional } \\
\text { - Ministério do Meio Ambiente }\end{array}$ \\
\hline Educação, Cultura, Ciência e Tecnologia e Esporte & $\begin{array}{l}\text { - Ministério da Educação } \\
\text { - Ministério da Cultura } \\
\text { - Ministério da Ciência e Tecnologia } \\
\text { - Ministério dos Esportes }\end{array}$ \\
\hline Planejamento e Desenvolvimento & - Ministério do Planejamento, Orçamento e Gestão \\
\hline Fazenda, Desenvolvimento e Turismo & $\begin{array}{l}\text { - Ministério da Fazenda } \\
\text { - Ministério do Desenvolvimento, Indústria e Comércio } \\
\text { - Ministeriorio do Turismo }\end{array}$ \\
\hline Justiça e Defesa & $\begin{array}{l}\text { - Ministério da Justiça } \\
\text { - Ministério da Defesa } \\
\end{array}$ \\
\hline Poderes do Estado e Representação & $\begin{array}{l}\text { - } \text { Presidência da República } \\
\text { - Ministério Público } \\
\text { - Ministério das Relações Exteriores }\end{array}$ \\
\hline Agricultura e Desenvolvimento Agrário & $\begin{array}{l}\text { - Ministério da Agricultura, Pecuária e Abastecimento } \\
\text { - Ministério do Desenvolvimento Agrário } \\
\text { - Ministério da Pesca e Aquicultura }\end{array}$ \\
\hline Trabalho, Previdência e Assistência Social & $\begin{array}{l}\text { - Ministério do Trabalho e Emprego } \\
\text { - Ministério da Previdência Social } \\
\text { - Ministério do Desenvolvimento Social e Combate à } \\
\text { Fome }\end{array}$ \\
\hline
\end{tabular}

Fonte: Elaboração própria com base na Resolução do Congresso Nacional no 1 de 2006 (BRASIL, 2006)

Cada um dos relatores setoriais destinados a ocupar essas áreas temáticas são escolhidos tendo em vista o atendimento da regra de proporcionalidade dos partidos na Câmara. Isso garante, por exemplo, que tantos os partidos que pertencem a coalizão de 
governo, quanto aqueles que não pertencem sejam escolhidos para ocupar o cargo da relatoria setorial. Uma vez no cargo, é de responsabilidade de cada um desses relatores a avaliação, apreciação e aprovação não só os recursos disponíveis propostos pelo Executivo para atender à sua área, bem como a apreciação e aprovação das emendas propostas a LOA.

Após a avaliação de todas as emendas e modificações ao projeto da LOA, os relatores setoriais entregam ao relator geral pareceres parciais a respeito da peça orçamentária. E é nesse momento que, mais uma vez, o relator geral entra em ação e elabora o parecer final da proposta orçamentária que segue para votação em plenário. Durante esse momento de elaboração do parecer final, vale aqui salientar, que o relator geral só pode fazer correções nos relatórios parciais apresentados. Em termos claros, significa afirmar que o Relator somente pode corrigir o que foi aprovado pelas relatorias setoriais. Fica vedada a possibilidade de aprovar emendas já rejeitadas e de propor novas obras ou despesas.

A etapa mais ativa de participação dos membros do Legislativo no orçamento com certeza é a etapa da apresentação das emendas de despesas. Essas emendas que podem ser incluídas no projeto da LOA, pelos parlamentares, geralmente são subdividas em dois tipos: as coletivas e as individuais. Dentre as emendas coletivas têm-se as emendas de comissões e as de bancadas estaduais. As emendas de comissões podem ser propostas pelas comissões permanentes tanto do Senado Federal quanto da Câmara dos Deputados e devem seguir as seguintes regras de proposição definidas pela última Resolução $\mathrm{N}^{\circ} 1$ de 2006 do Congresso Nacional: devem ser apresentadas o limite de no máximo quatro emendas, sendo duas de apropriação e duas de remanejamento para comissões com apenas uma área temática; e oito emendas sendo quatro de apropriação e quatro de remanejamento para comissões com mais de uma área temática.

No tocante as emendas de bancadas estaduais as regras definidas pela última Resolução do Congresso Nacional também são claras. É definido que os membros das bancadas do Congresso Nacional relativas a matérias e interesses de cada estado ou do Distrito Federal poderão propor no mínimo 15 e no máximo 20 emendas de apropriação além de três emendas de remanejamento. Sendo que as bancadas estaduais com mais de 11 parlamentares poderão apresentar uma emenda de apropriação para cada grupo 
completo de dez parlamentares. No caso das bancadas integradas por mais de 18 parlamentares o Senado Federal poderá apresentar três emendas de apropriação ${ }^{11}$.

A elaboração dessas duas emendas, vale lembrar, dependem de um esforço coletivo para serem aprovadas, ou seja, ambas dependem do resultado de um processo que exige um acordo entre membros de diferentes partidos ${ }^{12}$. Em ambos os casos, essas emendas exigem o consentimento de três quartos dos deputados e dois terços dos senadores para que uma emenda seja aprovada. Além disso, desde 2006 a cada ano o parecer preliminar da LOA, elaborado pelo relator geral da CMO, passou a estabelecer e definir quais serão os limites em valores e quantidades para essas emendas, principalmente para as de bancada.

As emendas individuais (objeto desta pesquisa), por sua vez, também se dividem em duas: aquelas propostas pelos parlamentares (deputados federais e senadores) e aquelas propostas pelos relatores setoriais e pelo relator geral. Após a CPI do Orçamento de 1993 as emendas inseridas nessa categoria sofreram importantes restrições, restrições estas que cresceram ao longo dos anos em função de reformas adicionais Até 1996, parlamentares brasileiros podiam propor emendas sem limite de valor. Contudo após o episódio de corrupção conhecido como "Anões do Orçamento" que envolvia relatores e a aprovação de valores de emendas individuais, essas emendas passaram a sofrer importantes restrições na quantidade e em valores ao longo dos anos.

Ademais, esta mudança também restringiu a possiblidade de apresentação de acréscimo de despesas pelos relatores. Desde a 1996, estabeleceu-se que aos relatores somente compete a proposição de emendas que corrijam erros de receita. Tanto os reatores setoriais, quanto o relator geral da proposta somente cabe o papel de aprovar/ rejeitar a proposição das emendas coletivas e individuais, bem como de fazer correções de receita na proposta original encaminhada pela Presidência da República.

Até o ano de 2011 (limite do recorte temporal proposto nesta dissertação), cada parlamentar individualmente tinha o direito garantido de propor um limite de vinte e cinco emendas no valor total de 13 milhões sendo que 2 milhões deveriam ser destinados obrigatoriamente para o Ministério da Saúde, enquanto que o restante podia ser direcionado para qualquer outro Ministério de acordo com a preferência e programa

\footnotetext{
${ }^{11}$ Informações retiradas do último Parecer Preliminar da LOA, referente ao ano de 2011.

12 As Comissões e as Bancadas estaduais, responsáveis pela apresentação das emendas denominadas de coletivas, são compostas por membros de diferentes partidos do Congresso Nacional. A proposição apresentação das emendas coletivas, portanto, depende da negociação e consenso de todos os membros, independente do partido que integram.
} 
escolhido pelo parlamentar e definidos anteriormente pela LDO. A Tabela 2 abaixo apresenta os limites com as quantidades e os limites de valores definidos pelos pareceres preliminares da LOA para a apresentação de emendas individuais.

Tabela 2: Quantidade e limite de valores das emendas individuais orçamentárias (1996-2011)

\begin{tabular}{|c|c|c|}
\hline Ano LOA & Quantidade de Emendas & Limite de Valores \\
\hline \hline 1996 & 20 & 1,5 Milhões \\
1997 & 20 & 1,5 Milhões \\
1998 & 20 & 1,5 Milhões \\
1999 & 20 & 1,5 Milhões \\
2000 & 20 & 1,5 Milhões \\
2001 & 20 & 1,5 Milhões \\
2002 & 20 & 2 Milhões \\
2003 & 20 & 2 Milhões \\
$2004^{*}$ & 20 & 2,5 Milhões \\
2005 & 20 & 3,5 Milhões \\
$2006^{*}$ & 20 & 5 Milhões \\
$2007^{*}$ & 25 & 6 Milhões \\
2008 & 25 & 7 Milhões \\
2009 & 25 & 8 Milhões \\
2010 & 25 & 12,5 Milhões \\
$2011^{* *}$ & 25 & 13 Milhões \\
\hline
\end{tabular}

Fonte: Elaboração própria com base nos Pareceres Preliminares da LOA ${ }^{13}$

* Nesses anos foi definido que 30\% do valor máximo das emendas deveriam ser destinadas para o Ministério da Saúde

** Nesse ano foi definido que $\mathrm{R} \$ 2000$ 000,00 deverão ser alocados na ação 8581 - Estruturação da Rede de Serviços de Atenção Básica de Saúde, com destino da verba para o Ministério da Saúde.

Ademais, o escândalo com os "Anões do Orçamento" também restringiu a possiblidade de apresentação de acréscimo de despesas pelos relatores. Desde a 1996, estabeleceu-se que aos relatores somente compete a proposição de emendas que corrijam erros de receita. Tanto os reatores setoriais, quanto o relator geral da proposta somente cabe o papel de aprovar/ rejeitar a proposição das emendas coletivas e individuais, bem como de fazer correções de receita na proposta original encaminhada pela Presidência da República.

Cabe destacar uma última regra estabelecida para a proposição das emendas de despesa. Como a Constituição de 1988 definiu, a proposição de emendas deve obrigatoriamente ser realizada somente em dois dos Grupos de Natureza da Despesa

\footnotetext{
${ }^{13}$ Os pareceres podem ser consultados em: http://www2.camara.leg.br/atividade-legislativa/orcamentobrasil
} 
(GND): Investimentos e Despesas Correntes. Aos demais grupos só são autorizadas as emendas que corrijam valores. Assim, parlamentares tomados individualmente ou coletivamente só podem propor emendas de despesa no que defini anteriormente como sendo a matéria-prima para a construção de políticas.

Após a apreciação das emendas aos projetos orçamentários, tanto o PPA, a LDO, a LOA e os créditos adicionais seguem para votação em plenário e no caso da LOA, uma vez que ela é aprovada, cabe ao Executivo definir os recursos que serão de fato executados ou não, tendo como base as prioridades do governo. A Figura 3 abaixo mostra de maneira resumida o caminho percorrido pela LOA no interior do Legislativo.

Figura 3: Tramitação da LOA no interior do Legislativo

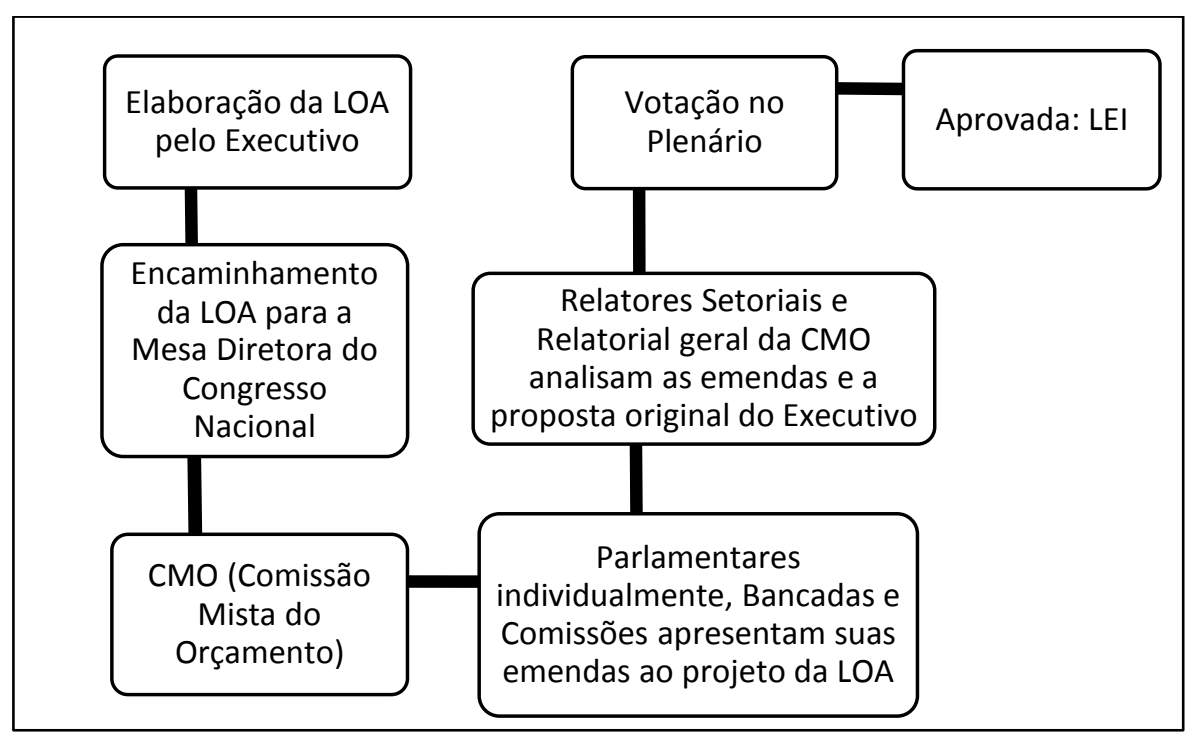

Fonte: Elaboração própria com as informações retiradas da Câmara dos Deputados

O que aqui foi apresentado, até o momento elucida, como a participação do Legislativo no orçamento era dada de maneira geral e mais atualizada até 2011. Mas o fato é que nem sempre a participação do Legislativo, principalmente dos parlamentares, no período pós 88 foi dada e estabelecida dessa forma. A próxima seção traz com maiores detalhes a evolução e as alterações realizadas quanto a participação de deputados e senadores na elaboração da peça orçamentária para o período.

Enfim, o que aqui se procurou demonstrar pode ser resumidos em dois pontos importantes que serão abordados adiante neste trabalho. O primeiro desses pontos é o de que o Legislativo de fato participa do processo de elaboração da LOA e das demais propostas orçamentárias. A apresentação das emendas de despesa não deixa os membros do Legislativo à margem do plano de políticas a ser realizado, como a literatura 
usualmente enfatiza. É dada aos parlamentares a oportunidade de alocar verbas, respeitadas as normas, nas políticas/programas que melhor traduzem suas preferências. $\mathrm{O}$ segundo ponto é quanto ao papel dos relatores, tanto os setoriais quanto o geral. Ambos são peças chaves fundamentais para controlar e adequar as propostas do Executivo. Ainda que o Legislativo não detenha o poder de propor legislação na área orçamentária, é dado aos parlamentares o poder de, ao menos, controlar e alterar as propostas originárias do Executivo que se encontram distantes da posição/ preferência política do seu partido.

\subsection{A evolução no tempo: ampliação e restrições da participação do Legislativo}

Os primeiros anos de vigência da nova Constituição foram marcados pela implementação de inúmeras alterações às normas e atribuições aos parlamentares no interior do Legislativo brasileiro. No âmbito da esfera orçamentária a história também não foi diferente. A organização da Assembleia Nacional Constituinte (ANC), instaurada ainda em 1987, dividiu e organizou os trabalhos em comissões e subcomissões temáticas $^{14}$ que ficaram encarregadas de elaborar, respectivamente, projetos $\mathrm{e}$ anteprojetos sobre o assunto ao qual foram designadas a tratar.

As matérias relacionadas ao orçamento brasileiro ficaram sobre a responsabilidade da Comissão de Sistema Tributário e da respectiva subcomissão de Orçamento e Fiscalização Financeira - ambas eram as responsáveis por definir como seria dada a participação do Legislativo no Orçamento. Como bem destacou Praça (2010), durante o processo da ANC a preocupação maior dos parlamentares envolvidos na comissão e subcomissão aqui citadas estava mais ligada à devolução do direito e a importância da retomada da participação do Legislativo nessa arena, do que ao estabelecimento de normas e regras propriamente ditas.

Ainda no primeiro anteprojeto ${ }^{15}$ apresentado e aprovado no interior da subcomissão de Orçamento e Fiscalização, quatro proposições importantes merecem

\footnotetext{
${ }^{14}$ De maneira geral a ANC funcionou assim: ao todo foram formadas 8 comissões temáticas que se subdividiram em outras 24 subcomissões. Cada subcomissão ficava responsável por elaborar um anteprojeto que depois de aprovado seguia para a comissão temática responsável. As oito comissões temáticas, por sua vez, ficaram encarregadas de sintetizar e organizar os anteprojetos em uma única proposta que deveria ser votada e aprovada em plenário. Para entender melhor todo o processo do estabelecimento, organização e aprovação dos trabalhos no interior da Assembleia Nacional Constituinte de 1986 ver Medeiros (2013).

15 Os anteprojetos das comissões, os projetos apresentados e aprovados pelas comissões, bem como as discussões podem ser consultadas em:
} 
destaque no que concerne a participação do Legislativo no orçamento. Um primeiro ponto diz respeito sobre a manutenção da Comissão Mista de Orçamento (CMO), criada ainda durante o regime militar, com o objetivo de analisar as matérias orçamentárias oriundas do Executivo ${ }^{16}$. Pelo anteprojeto apresentado, a CMO continuaria a ser a responsável não só por apreciar os projetos orçamentários apresentados pelo Executivo, bem como por aprovar ou rejeitar as emendas apresentadas a esses projetos no interior do Legislativo. Quanto a composição e constituição da CMO, ficou estabelecido que ficaria a cargo do Regimento Interno da Câmara definir as regras e critérios de sua composição.

O segundo ponto de destaque é quanto ao papel de fiscalização que o Legislativo deveria ter sobre o orçamento. De acordo com a proposta do anteprojeto, o Congresso Nacional juntamente com o Tribunal de Contas da União (TCU) é que seriam os responsáveis não só por analisar o orçamento, bem como por fiscalizar se a execução do mesmo seria dada de acordo com as regras estabelecidas. A motivação para ser atribuído ao Legislativo esse papel fiscalizador estava atrelada ao fato do orçamento continuar a ser autorizativo. Como o Executivo, em certa medida, seria livre para decidir quais gastos executar ou não dentre as provisões aprovadas na LOA, caberia ao Legislativo em conjunto com o TCU avaliar o quanto o Executivo estaria ou não seguindo os compromissos assumidos.

No tocante a apresentação de emendas aos projetos de leis orçamentárias, o anteprojeto da subcomissão definia que as emendas apresentadas aos projetos ligados ao orçamento ficariam restritas ao interior e análise da CMO. Para além disso, o anteprojeto também obrigava que as emendas deveriam estar de acordo com as políticas estabelecidas pelo PPA e a LDO. A última restrição que o anteprojeto colocou à apresentação das emendas é que estas deveriam indicar a fonte de financiamento como sendo provenientes de recursos oriundos de créditos adicionais ou de excesso de arrecadação. Destaca-se aqui que definições e limitações de valores e quantidades de emendas de despesa que o

\footnotetext{
http://www2.camara.leg.br/atividade-legislativa/legislacao/Constituicoes_Brasileiras/constituicaocidada/assembleia-nacional-constituinte/fundo-assembleia-nacional-constituinte/2

16 A Comissão Mista de Orçamento foi criada ainda em 1969, ainda sob o regime militar, com a aprovação da emenda $\mathrm{N}^{\circ} 1$ de 1969. Na seção IV que dispõe sobre o orçamento e no artigo 66 ficou definido que: $\S 1^{\circ}$ Organizar-se-á comissão mista de senadores e deputados para examinar o projeto de lei orçamentária e sobre ele emitir parecer. $\S 2^{\circ}$ Somente na comissão mista poderão ser oferecidas emendas. $\S 3^{\circ} \mathrm{O}$ pronunciamento da comissão sobre as emendas será conclusivo e final, salvo se um terço dos membros da Câmara dos Deputados e, mais um terço dos membros do Senado Federal requererem a votação em plenário de emenda aprovada ou rejeitada na comissão (BRASIL, 1969)
} 
Legislativo poderia apresentar não aparecerem e nem sequer foram inseridas no anteprojeto aprovado.

Na etapa posterior, ou seja, na análise e junção dos anteprojetos apresentados pelas subcomissões $^{17}$, o projeto aprovado pela Comissão de Sistema Tributário realizou algumas pequenas alterações nos pontos levantados acima. Sobre o primeiro deles, foi mantido no projeto final a apreciação pela $\mathrm{CMO}$ dos projetos ligados a arena orçamentária. Contudo, no que diz respeito a apreciação das emendas, foi retirado do projeto final o papel da CMO em aprovar e rejeitar as emendas, sem que nenhuma outra determinação fosse colocada no lugar. Para além disso, a CMO e não mais o Congresso Nacional é quem ficaria responsável, em parceria com o TCU, por fiscalizar a execução dos gastos orçamentários.

A grande alteração, no entanto, foi quanto a apresentação das emendas por parte dos membros do Legislativo. De acordo com o projeto, a apresentação das emendas ficaria restrita as verbas provindas do grupo de despesas (GND) de investimentos e, ainda, deveriam ter como fonte a anulação de despesas. Também foi incorporado ao projeto a apresentação de emendas aos créditos adicionais, possibilidade esta que não havia sido incorporada ao anteprojeto apresentado pela subcomissão de Orçamento e Fiscalização Financeira.

Ao final de todo o processo da ANC, com a aprovação do texto da Constituição de 88, mais uma alteração: o texto aprovado estabeleceu que a anulação de despesas não poderiam ser feiras com (i) com pagamento de pessoal; (ii) com serviços e pagamento da dívida e (iii) com transferências constitucionais para estados e municípios. A apresentação das emendas ficava, assim, ainda mais restrita à área de investimentos.

A Figura 4 abaixo apresenta a síntese das principais regras estabelecidas e modificadas durante a ANC.

${ }^{17}$ Ao todo a comissão temática de Sistema Tributário era composta por outras três subcomissões, quais sejam: Comissão do Sistema Tributário, Orçamento e Finança: Subcomissão de Tributos, Participação e Distribuição das Receitas; Subcomissão de Orçamento e Fiscalização Financeira e Subcomissão do Sistema Financeiro. 


\section{Figura 4: Principais alterações sobre a participação do Legislativo no orçamento durante a ANC.}

\begin{tabular}{|l|}
\hline \multicolumn{1}{|c|}{$\begin{array}{c}\text { Anteprojeto da Subcomissão de } \\
\text { Orçamento e Fiscalização Financeira }\end{array}$} \\
\hline •Permanência da CMO, bem como do \\
poder de apreciação das leis \\
orçamentárias e da aprovação e rejeição \\
das emendas. \\
• Papel de fiscalização do Congresso \\
Nacional em parceria com o TCU \\
•Apresentação de emendas realizadas no \\
interior da CMO \\
•Apresentação das emendas de acordo \\
com o PPA e a LDO. \\
• Fonte da apresentação das emendas: \\
créditos adicionais ou execsso de \\
arrecadação \\
\end{tabular}

\begin{tabular}{|l|}
\hline \multicolumn{1}{|c|}{ Projeto da Comissão de Sistema } \\
Tributário
\end{tabular}

\begin{tabular}{|l|}
\hline Constituição de 1988 \\
\hline •Manteve a CMO, bem como a \\
apreciação das leis orçamentárias. \\
Continuou ausente texto sobre a \\
apreciação das emendas. \\
- Manteve o papel fiscalizador da CMO \\
em parceria com o TCU. \\
- Manteve a apresentação das emendas \\
no inteiror da CMO. \\
- Manteve a apresentação das emendas \\
de acordo com o PPA e a LDO. \\
-Manteve a fonte de apresentação das \\
emendas como sendo na área de \\
investimentos, mas alterou a fonte da \\
anulação dos gastos impondo restrições \\
quanto ao cancelamento de pagamento \\
de pessoal, encargos da dívida e \\
transferências constitucionais. \\
\hline
\end{tabular}

Fonte: Elaboração própria com base nos relatórios finais e projetos da ANC e da Constituição brasileira de 1988.

Em nenhum momento limites de valores e quantidades foram impostos à apresentação das emendas por parte dos membros do Legislativo. Também não foram estabelecidos os critérios de avaliação dessas emendas. A consequência disso, conforme argumentam Figueiredo e Limongi (2008a), Praça (2010) e Martins (2012) foi a de que os anos subsequentes a promulgação da Constituição ficaram marcados pela inexistência de uma norma regimental apta a operacionalizar as novas e numerosas atribuições devolvidas aos membros do Legislativo.

Em virtude disso entre os anos de 1988 e 1991 vigoraram regras informais, ora definidas por Nelson Carneiro, então presidente do Congresso Nacional na ocasião, ora definidas pelo deputado federal Cid Carvalho, então presidente na CMO entre 1988 e 1990. Até a promulgação da primeira Resolução do Congresso Nacional $n^{\circ} 1$ de 1991(BRASIL, 1991) - que veio a estabelecer o "como" o Legislativo deveria atuar na peça orçamentária - técnicos da equipe do Executivo e dos Ministérios eram alocados até o Congresso para auxiliar na formatação das primeiras leis orçamentárias (SANCHES, 1995).

A adoção das resoluções do Congresso Nacional procurou resolver os problemas decorrentes da ausência de regras bem estabelecidas e definidas para a participação do 
Legislativo no orçamento brasileiro. A primeira dessas resoluções foi a de $n^{\circ} 1$ de 1991. Composta por 28 artigos, essa resolução tratou especificamente das atribuições e competências da CMO, bem como de sua composição. Também foi estabelecido que o relator geral da comissão é que seria o responsável por avaliar e dar o parecer sobre as emendas apresentadas aos projetos orçamentários. Ademais essa resolução só formalizou o que já havia sido definido anteriormente com a Constituição.

O fato é que apesar de estabelecer regras para a elaboração do orçamento no Legislativo, a Resolução no 1 de 1991 - CN ainda era muito vaga e não trazia nenhuma instrução em seu texto sobre a apresentação de emendas que visavam a alteração das receitas e despesas estimadas e definidas pelo Executivo. A ausência dessas regras foi um dos principais motivos e facilitadores do que, dois anos após, veio a se tornar um dos maiores escândalos de corrupção no Brasil envolvendo justamente a participação do Legislativo na elaboração do orçamento.

O esquema de corrupção conhecido como "Anões do Orçamento" teve início, de acordo com a comissão de inquérito parlamentar instaurada para investigar o caso (também conhecida como CPI do orçamento), ainda no ano de 1989, ano esse que marcava justamente o retorno do Legislativo na participação do orçamento. Segundo o relatório final apresentado pela comissão, havia dois esquemas que funcionavam paralelamente: um primeiro esquema que ficou conhecido como o esquema das empreiteiras, pois envolvia as emendas individuais orçamentárias, as emendas de autoria do relator geral e importantes empreiteiras. E um segundo esquema que ficou conhecido como esquemas das subvenções, por envolver a criação de entidades por parte de familiares dos parlamentares e a troca entre eles de emendas individuais orçamentárias.

Sobre o primeiro desses esquemas, o que envolvia as empreiteiras, o esquema de corrupção tinha início ainda no Executivo, mais especificamente na etapa de elaboração da Lei Orçamentária Anual (LOA) realizada pelos Ministérios. Nessa etapa, os grupos de interesse e lobistas faziam pressão e estabeleciam acordos para que determinadas obras que os beneficiavam fossem incluídas na LOA. Quando a proposta da LOA chegava até o Legislativo na Comissão Mista de Orçamento (CMO), o esquema tinha sequência e esses mesmos grupos de interesse ligados as grandes empreiteiras realizavam acordos com um grupo seleto formado por oito parlamentares ${ }^{18}$ que ficavam responsáveis, então,

\footnotetext{
${ }^{18} \mathrm{O}$ nome Anões do Orçamento é decorrente justamente por esse grupo ser composto por oito parlamentares de baixa estatura.
} 
por garantir a aprovação de emendas individuais orçamentárias e de emendas de relator em áreas e obras específicas de atuação dessas empreiteiras.

Foi assim, por exemplo, que o deputado João Alves (PPR-BA), então relator geral da CMO em 1990 e considerado um dos líderes do esquema, conseguiu destinar mais de 1,90 bilhões de cruzeiros em emendas individuais para obras do Ministério da Ação Social -reconhecido na época por ser um dos principais Ministérios onde lobistas atuavam. Conforme apontado pelo próprio relatório final apresentado:

Esse grupo atuou com desenvoltura até o Orçamento de 1992. Os grupos de pressão garantiam a aprovação das emendas de seu interesse mediante ao oferecimento de vantagens indevidas. Cada sub-relator tinha a função de negociar com os parlamentares as emendas apresentadas. Quando se tratava de um dos integrantes do esquema, esse sub-relator participava diretamente das negociações, contatando empreiteiras e representantes dos grupos de pressão, segundo denúncia do Sr. José Carlos Alves dos Santos. Para garantir o sucesso das negociações e da aprovação das emendas de seu interesse, o membro do esquema que fazia as vezes de relator assegurava a aprovação de razoável número de emendas de outros parlamentares conquistandolhes o apoio. (BRASIL, 1994, p. 371)

Uma vez que essas emendas eram aprovadas, os grupos de interesse voltavam a fazer pressão nos Ministérios para que essas emendas fossem liberadas. Após a liberação da obra, as empreiteiras realizam o pagamento da propina diretamente para os relatores e sub-relatores que ficavam encarregados de realizar a distribuição do dinheiro entre os demais parlamentares que apresentaram tais emendas.

O segundo esquema, o das subvenções, também envolvia a aprovação das emendas individuais orçamentárias. Nesse caso, parlamentares criavam entidades que eram controladas por familiares e trocavam entre eles emendas orçamentárias. De forma simples e resumida o esquema das subvenções era operado da seguinte forma: o parlamentar A destinava emendas para a entidade do parlamentar B que, em troca, destinava suas emendas para a as entidades controladas pelos familiares do parlamentar A.

Dado o controle e poder do relator geral da $\mathrm{CMO}$ em avaliar e alterar a proposta orçamentária, muitas das emendas que estavam ligadas tanto ao esquema das empreiteiras, quanto as emendas envolvidas com as subvenções eram incluídas somente na etapa final da apreciação da peça orçamentária na CMO. Logo, o projeto orçamentário que chegava até o plenário para ser votado constituía-se como uma verdadeira "caixapreta" e somente se fazia compreensível para o núcleo seleto composto pelos oito 
parlamentares membros da CMO e pelos demais parlamentares envolvidos tanto com o esquema das empreiteiras, quanto com o esquema das subvenções.

Em meio as investigações da CPI do orçamento e sob a justificativa de que era preciso evitar os atrasos na aprovação da Lei Orçamentária Anual - atraso este causado pelo excesso de emendas - foi aprovada em junho de 1993 a Resolução do Congresso Nacional de $n^{\circ} 1$ de 1993 (BRASIL, 1993), cujo principal objetivo foi justamente o de alterar a resolução anterior e reduzir não só o número de integrantes da $\mathrm{CMO}$, bem como o de estabelecer limites para a apresentação das emendas de despesa no Legislativo.

Apesar de propor importantes alterações quanto ao número de parlamentares a integrar a CMO, a principal discussão e divergência na aprovação dessa resolução foi quanto a limitação da quantidade de emendas individuais. $\mathrm{O}$ único ponto em que ambos parlamentares concordaram era o de que, dada as suspeitas de práticas ilícitas envolvendo as emendas individuais orçamentárias - vale ressaltar aqui mais uma vez que essa resolução foi aprovada em meio a uma das maiores investigações de práticas corruptas no orçamento -, era preciso manter e fortalecer a participação do Legislativo no orçamento.

A divergência quanto a limitação das emendas partiu justamente do que alguns parlamentares interpretaram ser o fortalecimento da participação do Legislativo no orçamento. Enquanto para uns a limitação das emendas era vista como uma oportunidade de melhorar não só a imagem do Legislativo perante a sociedade, bem como fortalecer sua participação agilizando o tempo de alteração e apreciação da proposta no Congresso, para outros a limitação da quantidade de emendas enfraquecia o Legislativo não só por reduzir o trabalho do parlamentar, como também por desmerece-lo. Nas próprias palavras do deputado federal à época Nelson Marquezelli (PTB-SP):

[...]. Não concordo, em hipótese alguma, com esse limite. Foi um erro limitarmos e ainda colocarmos as emendas coletivas dentro desse limite. Tudo isso vai fazer com que a Casa atenda apenas à grande imprensa, àqueles comentaristas que criticam a atuação do parlamentar, a atuação daquele que quer trabalhar, apresentando emendas construtivas. [...] não se pode penalizar aquele parlamentar que quer apresentar um número maior de emendas e sugestões. É um trabalho construtivo, é um trabalho do seu gabinete, da sua assessoria, daqueles que militam nos municípios. Acho que poderíamos fazer uma apreciação melhor. (Dep. Nelson Marquezelli, Bloco SP na Câmara, DCN 3/06/1993, p. 1127) 
Mesmo com as divergências claras existente entre os parlamentares a resolução No 1 de 1993 foi aprovada e trouxe em seu texto não só a definição clara das emendas e autores proponentes, bem como fixou seus limites em termos de quantidade. De acordo com a redação final do texto aprovado as emendas deveriam seguir a tais critérios de proposição e quantidades:

- Emendas individuais: apresentação de no máximo 50 (cinquenta) emendas individuais para cada parlamentar. Não há alteração quanto as emendas de relatores;

- Emendas de Comissão: apresentação de no máximo 3 (três) emendas para cada comissão permanente do Senado Federal e da Câmara dos Deputados;

- Emendas partidárias: apresentação de 1(uma) emenda para cada grupo de 10 (dez) parlamentares dentro de um mesmo partido e 1 (uma) emenda para os partidos que não atinjam 10 (dez) parlamentares;

- Emendas de Bancada: sem limites de quantidade e valores. Garantia de apresentação de no máximo 3 (três) emendas por parlamentares (deputados e senadores) que componham a bancada estadual.

Para além da definição e restrição quanto ao a apresentação de emendas de despesas, a resolução aprovada em 1993 também alterou a composição da CMO. Se antes ela deveria ser composta por 120 membros titulares, dos quais 90 deveriam ser deputados federais e 30 senadores, pelas novas regras adotadas a comissão passou a ser composta por 84 membros, sendo 63 deputados e 21 senadores.

O fato é que essa resolução não teve muitos anos de duração. Em abril de 1994, ao final das investigações do esquema de corrupção envolvendo a participação do Legislativo no orçamento, a CPI do orçamento instaurada chegou à conclusão de que o Legislativo brasileiro ainda não se encontrava preparado e equipado o suficiente para lidar com a elaboração, apreciação e aprovação do orçamento. De acordo com relatório final apresentado pelo deputado federal Roberto Magalhães (PFL-PE), relator da CPI: 
Ao longo do tempo, a apreciação do projeto orçamentário se revestiu de características de dificuldade técnica que impediam a transparência do processo. Colaborava para tal situação o desaparelhamento de material e de regras do Legislativo.

A lei orçamentária tem sido, na prática, elaborada em interação com o Departamento de Orçamento da União, sem que, por muito tempo, tivesse o Legislativo atingido necessário estágio de aparelhamento técnico e de recursos humanos para uma perfeita compreensão de todas as suas complexidades.

Essa própria dificuldade facilitou a emergência de um núcleo de poder dentro da Comissão Mista de Orçamento, que esperava contrapartida por parte de autoridades encarregadas da elaboração e da execução orçamentárias no Poder Executivo.(BRASIL, 1994, p. 8 VolumeIII)

A constatação de que o Legislativo não se encontrava preparado para lidar com o orçamento não foi a única conclusão na qual a CPI chegou. O relatório final também apresentou sugestões para a modificação e modernização do sistema de elaboração do orçamento. Com um discurso de que o orçamento, bem como a participação dos membros do Legislativo em sua elaboração deveriam acontecer de maneira mais clara e transparente, as principais recomendações no tocante a organização e formatação do orçamento no Legislativo foram:

i. Elaboração conjunta entre Executivo e Legislativo da proposta orçamentária;

ii. Discussão e elaboração da Lei de Diretrizes Orçamentárias (LDO) no interior de todas as comissões temáticas permanentes da Câmara dos Deputados e do Senado Federal, sendo que em todas as comissões é obrigatória a participação de membros dos Ministérios correlatos às áreas de atuação das comissões;

iii. Extinção da Comissão Mista de Orçamento (CMO);

iv. Restauração das comissões de fiscalização e controle da Câmara e do Senado;

v. Autorização e execução somente de obras que tenham recursos suficientes para serem concluídas;

vi. Limitação do poder de emendar a Lei Orçamentária, com forte recomendação para que fossem extintas as emendas individuais orçamentárias (isso inclui as emendas de relatores);

As sugestões feitas pela CPI do orçamento surtiram efeito. Depois de amplo debate no interior do Congresso, em 14 de setembro de 1995 teve origem a Resolução de $n^{\circ} 2$ de 1995 do Congresso Nacional (BRASIL, 1995), resolução esta que, de fato, pela 
primeira vez desde 1989, estabeleceu e definiu regras claras para a participação do Legislativo na elaboração do orçamento

A primeira grande modificação, e não poderia ser diferente, foi realizada em relação ao poder de apreciação, alteração e apresentação de emendas por parte dos relatores gerais, considerados como o epicentro do esquema de corrupção dos "Anões do Orçamento". Pelas novas regras vigentes, a análise da peça orçamentária, bem como a apreciação das emendas seria dividida em sete subcomissões temáticas a serem compostas por até 20 parlamentares e um relator-setorial. Cada subcomissão temática, por sua vez, ficava responsável por emitir um parecer sobre a proposta do Poder Executivo e sobre as emendas apresentadas pelos parlamentares.

Uma vez que esses pareceres eram produzidos, o relator geral em conjunto com relatores adjuntos, designados para "fiscalizar" o trabalho de apreciação da peça orçamentária pelo relator geral, ficavam encarregados de elaborar o parecer final da lei orçamentária a ser votado no plenário da CMO. Nessa etapa do processo, foi retirada do relator geral a possibilidade de (i) apresentar emendas contendo novas despesas abarcando novas obras e (ii) de aprovar emendas anteriormente rejeitadas pelos relatores setoriais.

Apesar dessas modificações terem introduzido importantes restrições quanto ao papel de alteração da peça orçamentária pelos relatores gerais, o mesmo não pode ser afirmado quanto ao papel deste em organizar a participação do Legislativo no orçamento. De acordo com o artigo $15^{\circ}$ da resolução adotada em 1995, ficou estabelecido que era de responsabilidade do relator geral a elaboração de um parecer preliminar que contivesse as regras e normas às quais cada relator setorial e adjunto deveriam seguir para a apreciação do orçamento em suas respectivas áreas, bem como para a apreciação e aprovação das emendas propostas tanto por parlamentares individualmente, quanto coletivamente.

Pelas novas regras estabelecidas, também ficou definido que caberia ao relator geral o papel de definir o limite das despesas que estariam disponíveis para que cada relator setorial disponibilizasse para o atendimento das emendas em suas respectivas áreas temáticas. De forma mais clara, ficou estabelecido que o relator geral é quem definiria o limite de despesas que poderiam ser remanejadas no interior das sete áreas temáticas criadas para a apreciação e alteração da proposta orçamentária no Legislativo. Assim, se por um lado, a adoção da nova resolução colocou limites para a participação do relator geral deixando-o restrito a apreciação da peça orçamentária e a apresentação 
de emendas cuja finalidade fosse estritamente ligada a correção de despesas, por outro, ela deu ao relator geral um papel em nada desprezível: o de organizar e, de certa forma, controlar a apreciação e alteração do orçamento no Legislativo como um todo.

Ano após ano, os pareceres preliminares da Lei Orçamentária Anual (LOA) apresentam-se como as normas que deverão ser seguidas pelo Legislativo para a alteração do orçamento. Como dito na seção anterior, é justamente sobre esses pareceres preliminares que fica estabelecido não só o limite de valores e quantidade das emendas individuais e coletivas, bem como o montante disponível em verbas que o Legislativo terá para remanejar o orçamento e colocar nele suas preferências. Indo além, esses pareceres não são só definidores da participação do Legislativo, eles são também a tradução formal da negociação e acordo zelado que o relator geral tem que fazer com o Executivo para conseguir conciliar o interesse de ambos, ou seja, tanto do Legislativo, quanto do próprio Executivo. O relator não só é, como deve sempre ser, o agente da coalizão capaz de realizar o meio de campo entre a preferências das duas arenas decisórias.

Outra alteração significativa introduzida pela resolução $\mathrm{n}^{\circ} 2$ de $1995-\mathrm{CN}$ foi quanto a autoria e a quantidade das emendas de despesas a serem apresentadas. Pela nova regra vigente ficou estabelecido que as emendas coletivas - tidas como a soma das emendas de bancada estadual, das emendas de comissão e das emendas de bancada regional - teriam prioridade na alocação de recursos e na proposição de novas obras. Em contrapartida, as emendas individuais sofreriam significativas restrições quanto a valores e quantidades. De acordo com a resolução a proposição de emendas ficou assim definida:

- Emendas individuais: Apresentação de no máximo 20 (vinte) emendas individuais para cada parlamentar, sendo que o parecer preliminar a ser elaborado para a Lei Orçamentária Anual (LOA) estabeleceria limites de valores de acordo com a receita disponível para as alterações do Legislativo. Vedado aos relatores a proposição de novas emendas, restringindo a participação destes à apresentação de emendas cuja finalidade fosse única e exclusivamente a de correção de despesas;

- Emendas de comissão: Apresentação de no máximo 5 (cinco) emendas para cada comissão permanente do Senado Federal e da Câmara dos Deputados;

- Emendas de bancada: Apresentação de no máximo 10 (dez) emendas para cada bancada estadual e para o Distrito Federal; 
- Emendas regionais: Apresentação de no máximo 5 (cinco) emendas por regiões macroeconômicas definidas pelo IBGE;

Não foi sem discussão que as emendas individuais sofreram essas restrições. Assim como aconteceu em 1993 e sob a alegação de que era preciso fortalecer a participação do Legislativo no orçamento, bem como melhorar a imagem dessa participação perante a população, muitos foram os parlamentares que procuraram defender a extinção das emendas individuais. As palavras do deputado Sérgio Carneiro (PDT-BA) resumem bem o acordo final sobre a manutenção dessas emendas Nas palavras do próprio Deputado não era possível retirar do parlamentar uma de suas principais ferramentas capaz de fazer valer a representação das vontades de seu eleitorado. Era preciso pensar mais na qualidade dessas emendas, do que em sua restrição.

[...]. Não é possível que se parta de uma premissa de que todo tecnocrata honesto e todo paramentar deve ser colocado sob suspeita. Nós que representamos aqui o povo brasileiro, nós que representamos aqui todas as regiões deste pais, nós que conhecemos o país que juramos representar nesta Casa, estamos tolhidos em virtude do limite do número de emendas.

[...] Precisamos, Sr. Presidente, Sras. e Srs. Congressistas é de um debate mais aprofundado a respeito das questões orçamentárias. Dispomos da LDO e do Plano Plurianual para nortear a elaboração dessas emendas, com critérios muito bem definidos. Essas emendas têm de ser compatíveis com o Plano Plurianual e a Lei de Diretrizes orçamentárias- repito. Devem indicar os recursos de onde eles saem, as rubricas que devem ser anuladas para que outras possam ser criadas. Há que se dar prioridades as obras inacabadas ou em andamento. Há que se discutir de forma séria os problemas deste país e não fazer aqui uma espécie de self-service dessas emendas com emendas para todos os gostos. [...] A questão não é de quantidade. Estão estabelecidas 20 emendas, como poderiam estar estabelecidas 200. A questão não é de quantidade, mas de qualidade. A qualidade que um Parlamentar deve imprimir ao seu mandato, a qualidade da apresentação das suas emendas na responsabilidade e na representatividade de que ele está investido. (Dep. Sérgio Carneiro, PDT- BA, DCN 15/09/1995, p. 5717)

Um último destaque que cabe aqui quanto as regras impostas para a apresentação de emendas ao orçamento é o de que as emendas partidárias - propostas deste 1989 e formalizadas com a resolução ${ }^{\circ} 1$ de 1993 - foram extintas com a adoção da resolução $\mathrm{n}^{\text {o }} 2$ de 1995. Não há, nas discussões do texto da resolução, nenhuma menção ou comentário dos parlamentares quanto a supressão dessas emendas. A suspeita nesse caso 
é que a exclusão dessas tenha acontecido em momento anterior da negociação e discussão dessa nova resolução. Como esta foi apresentada e sugerida pela mesa diretora do Congresso Nacional, muito provavelmente o acordo para a extinção das emendas partidárias tenha sido dado em reuniões sigilosas entre os líderes partidários e os integrantes da mesa.

Nos anos seguintes, a resolução $\mathrm{n}^{\circ} 2$ de 1995 - CN parece ter correspondido as necessidades as quais se propôs. Se o objetivo geral da adoção da resolução era o de finalmente criar normas para guiar o comportamento dos legisladores no orçamento e, assim, evitar comportamentos desviantes e escândalos de corrupção, a resolução cumpriu com sua finalidade. Entre setembro de 1995 até outubro de 2001 não houve nenhuma suspeita de casos de corrupção envolvendo as emendas individuais orçamentárias e as emendas de relatores, alvos das investigações anteriores.

Embora a ordem tenha sido mantida na apreciação e alteração da peça orçamentária no interior do Legislativo durante esses anos, a aprovação da lei complementar $\mathrm{n}^{\circ} 101$ de 4 de maio de 2000, mais conhecida como a Lei da Responsabilidade Fiscal (LRF) ${ }^{19}$, acarretou na necessidade de alteração da resolução anterior vigente. Foi assim que a resolução $\mathrm{n}^{\circ} 1$ de 2001 do Congresso Nacional (BRASIL, 2001) veio a substituir e alterar as regras que estavam vigorando desde 1995.

Dentre as alterações realizadas pela resolução ${ }^{\circ} 1$ de 2001 cinco delas merecem destaque. A primeira delas foi quanto a incorporação de mais uma competência da CMO que passou a examinar e emitir pareceres sobre os documentos pertinentes ao acompanhamento da fiscalização, da execução orçamentária e financeira e da gestão fiscal $^{20}$. A segunda alteração, correlacionada a primeira, estabeleceu a criação de mais dois novos relatores, para além dos relatores já designados para avaliar o PPA, a LDO e a LOA: um relator para analisar e avaliar as contas do Executivo referentes ao exercício anterior e mais um relator para a análise da prestação de contas do próprio Tribunal de Contas da União $(\mathrm{TCU})^{21}$.

A terceira modificação realizada foi quanto a criação de três comitês que, sob a coordenação do relator geral, ficaram encarregados de avaliar, respectivamente, a receita orçamentária, as emendas apresentadas e a validade das informações enviadas pelo TCU.

\footnotetext{
${ }^{19}$ Criada com o objetivo principal de melhorar a administração das contas públicas no Brasil, a LRF veio estabelecer critérios, normas e metas para o controle do orçamento nas esferas municipal, estadual e federal. ${ }^{20}$ Ver Capítulo 1, artigo $2^{\circ}$ e inciso III da Resolução n ${ }^{\circ} 1$ de 2001-CN.

${ }^{21}$ Ver Capítulo 2, artigo $9^{\circ}$ da Resolução no 1 de 2001-CN.
} 
A ideia principal aqui era a de munir o relator geral de ferramentas capazes de fazê-lo cumprir de forma satisfatória com novas normas impostas pela Lei de Responsabilidade Fiscal. A surpresa maior e de maior impacto para o funcionamento da apreciação do orçamento no Legislativo foi quanto a extinção dos relatores adjuntos e a fixação de 10 (dez) áreas temáticas, com seus respectivos relatores setoriais a serem escolhidos de acordo com o princípio da proporcionalidade partidária do Congresso Nacional. Dessa forma, o orçamento passou a ser obrigatoriamente dividido para alteração e avaliação em dez áreas temáticas atreladas aos Ministérios afins.

Com essa nova alteração, a peça orçamentária passou a ser distribuída entre os relatores setoriais e finalizada, com a junção dos relatórios setoriais em um único parecer final, pelo relator geral. Ainda que as restrições quanto a apresentação de emendas de despesa e a criação de novas obras permanecesse, a resolução $n^{\circ} 1$ de 2001-CN reforçou ainda mais o papel do relator geral em (i) formular o parecer preliminar que estabelece os procedimentos para a apreciação e alteração do orçamento no legislativo; (ii) definir o montante das despesas disponíveis, no total e por área temática, para o remanejamento dos parlamentares e (iii) finalizar o parecer final da peça orçamentária a ser votado em plenário.

Outra alteração importante diz respeito quanto as regras para apresentação e aprovação das emendas de bancada. Na resolução adotada anteriormente, resolução $\mathrm{n}^{\circ} 1$ de 1995-CN, ficou estabelecido somente o limite em quantidade para a apresentação dessas emendas. Contudo, o mesmo não aconteceu com as normas estabelecidas pela resolução $n^{\circ} 1$ de 2001. Pela redação do texto aprovado a nova resolução determinou que as emendas de bancada deveriam ser aprovadas por nada mais, nada menos do que dois terços dos deputados e senadores integrantes da bancada. É bem verdade que a resolução aumentou o limite de quantidade dessas emendas que passou de 10 para a apresentação de no mínimo 15 e no máximo 20 emendas, no entanto as regras para a aprovação não só se tornaram mais rígidas, como também passaram a incentivar ainda mais o trabalho coletivo.

Por fim, a quinta e última alteração de destaque dessa nova resolução veio com a inclusão das audiências públicas. De acordo com o artigo $12^{\circ}$ a CMO passou a ter o direito de realizar audiências públicas com o objetivo de aprimorar não só os projetos e políticas previstas pelo PPA, pela LDO e pela LOA, bem como para o aprimoramento de suas de suas novas atribuições quanto ao acompanhamento e fiscalização da execução orçamentária e financeira. 
No entanto, a resolução ${ }^{\circ} 1$ de 2001- CN durou muito pouco. Em 2006 com a descoberta de mais um episódio de corrupção envolvendo novamente a participação do Legislativo na elaboração do orçamento, uma nova resolução foi elaborada. Dessa vez o esquema de corrupção que resultou da adoção de novas regras ficou conhecido como "Sanguessugas" e envolveu a participação ativa de parlamentares, prefeituras e empresas.

De acordo com o relatório apresentado pela Comissão de Inquérito Parlamentar instaurada, também apelidada como CPI das Ambulâncias, o grupo liderado pelos empresários Luiz Antônio Vedoin e Darci Vedoin, donos da Planam - empresa que fabricava ambulâncias -, pagava propina aos parlamentares em troca de emendas destinadas à compra de ambulâncias e materiais hospitalares. Ainda, de acordo com a denúncia, um grupo de parlamentares viabilizava a aprovação das emendas e intercedia nas prefeituras para direcionar as licitações para que as empresas controladas pela família Vedoin vencessem as disputas.

Não foi sem espanto que o relatório final apresentado por essa CPI, de maneira semelhante ao que foi apresentado na CPI do Orçamento, sugeriu o fim das emendas individuais. Para o relator da CPI, o senador Amir Lando (PMDB-RO), a extinção das emendas individuais não era só uma necessidade clara, mas também a solução para o problema de desvio de dinheiro no interior do Congresso:

\footnotetext{
A conclusão lógica que se impõe, como resultado do relatório acima, é a extinção das transferências voluntárias. Tal entendimento vem corroborado por declarações peremptórias do Ministro do Planejamento, Paulo Bernardo, em depoimento a esta CPMI, que por duas vezes afirmou que sua a solução mais adequada para a solução do problema é a extinção das transferências voluntárias, ressalvando, no entanto, a necessidade de que tal medida seja tomada mediante pacto que impeça, definitivamente, o retorno da prática de apresentação de emendas individuais ao orçamento pelos parlamentares.(Senador Amir Lando, PMDB- RO, BRASIL, 2006)
}

Apesar dessa recomendação, a resolução adotada em 2006 (BRASIL, 2006) não extinguiu as emendas individuais orçamentárias e, ao contrário do que era previsto, acabou impondo novas regras para a apresentação das emendas coletivas, sobretudo no tocante a apresentação das emendas de bancada estadual. Isso porque, como argumentaram Tollini (2008), Praça (2010) e Greggian et al (2011), essas emendas eram na verdade emendas conhecidas como "rachadinhas", ou seja, eram emendas repartidas 
entre os parlamentares da bancada para o atendimento de suas necessidades eleitorais individuais, sem existir, portanto, o predomínio de interesses coletivos.

De acordo com o artigo $47^{\circ}$ da nova resolução adotada, as emendas de bancada estadual passaram a ter que, obrigatoriamente, seguir um padrão novo de apresentação das propostas para serem aprovadas. A primeira modificação foi quanto a questão do quórum exigido para a aprovação de uma emenda. Se antes pela resolução ${ }^{\circ} 1$ de 2001 $\mathrm{CN}$ elas deveriam obrigatoriamente ser aprovadas por dois terços dos deputados e senadores, a nova resolução passou a exigir a aprovação de três quartos dos deputados e de dois terços dos senadores. A novidade, no entanto, não foi só essa. Também foi definido que junto de cada emenda deveria ser apresentada a ata da reunião na qual a aprovação da emenda foi decidida.

Apesar dos limites relacionados a quantidade de emendas não ter sido alterado apresentação de no mínimo 15 emendas e máximo de 20 - as emendas de bancada também passaram a ter que apresentar projetos que (i) visassem uma obra específica e sua conclusão, (ii) contivessem um cronograma de execução com prazos e previsões para os gastos e (iii), o mais importante, definissem uma única localidade como alvo da obra. Em termos claros e objetivos, essas novas regras foram impostas, justamente, para evitar as a proposição de emendas individuais travestidas de coletivas.

Não foram só as emendas de bancada que sofreram restrições com a adoção da resolução no 1 de 2006-CN. As regras para a apresentação e aprovação das emendas de comissão também sofreram alterações. Uma das primeiras modificações foi quanto as quantidades estabelecidas para a apresentação das emendas que passaram de no máximo 5 para 8. Além disso, assim como as emendas de bancada, essas emendas também passaram a ter a necessidade de serem aprovadas por três quartos dos deputados e de dois terços dos senadores membros da comissão, a necessidade de apresentar a ata da reunião como documento comprobatório da aprovação da emenda e, o mais importante, a necessidade de apresentar emendas com um caráter nacional e correlato com a área de atuação da respectiva comissão permanente. Assim, por exemplo, ficou estabelecido que a Comissão de Educação deveria apresentar emendas não só relacionadas a área de educação, bem como de caráter nacional, não sendo direcionada para nenhuma localidade (município ou estado) específica.

Quanto a apresentação de emendas individuais chama a atenção as poucas modificações e sanções realizadas. Mesmo após o envolvimento das mesmas em mais um escândalo de corrupção, a resolução $n^{\circ} 1$ de 2006 -CN alterou o limite de apresentação 
das emendas de 20 para 25. As únicas sanções impostas foram quanto a necessidade de apresentar emendas de acordo com as obras previstas e definidas como prioritárias pela LDO e de propor valores suficientes para a conclusão de uma obra. Tirando essas alterações, a nova resolução adotada manteve o papel do relator geral, na apresentação do parecer preliminar, de definir os limites, em valores, que cada parlamentar tem anualmente para a apresentação de suas emendas.

Apesar de alterar significativamente a participação do Legislativo no orçamento, a resolução $n^{\circ} 1$ de 2006-CN não trouxe somente modificações quanto a proposição de emendas. De forma mais abrangente, essa resolução trouxe a clareza que faltava para o entendimento não só dos procedimentos de apreciação e aprovação do orçamento no Legislativo, bem como para o papel a ser desempenhado por cada legislador. Apesar de não apresentar nenhuma alteração de impacto quanto ao papel a ser desempenhado pelo relator geral, a nova resolução adotada definiu, por exemplo, a quantidade de relatorias setoriais a serem ocupadas tanto pelos senadores, quanto pelos deputados nos casos em que o relator geral pertence a Câmara dos Deputados ou ao Senado. Nesse quesito, também ficaram estabelecidas as dez áreas temáticas de apreciação da proposta do orçamento e de atuação de cada relator setorial.

Quanto as responsabilidades e atribuições da CMO, para além da maior clareza quanto a divisão e definições de tarefas - principalmente quanto a divisão dos trabalhos em relatorias, a análise da proposta por comitês especializados e a inclusão de regras mais claras para a apreciação e aprovação da LDO e do PPA -, a resolução aprovada em 2006 também alterou a quantidade de membros da CMO, bem como suas atribuições. Quanto a quantidade, a CMO passou a ser composta 40 membros titulares, sendo 30 (trinta) Deputados e 10 (dez) Senadores. Quanto as suas atribuições, a CMO passou a não só a analisar os projetos relacionados a área orçamentária, como também passou a apreciar e dar parecer acerca da adequação financeira e orçamentária das medidas provisórias.

Composta por 161 artigos e dado o seu nível de detalhamento e esclarecimento quanto aos procedimentos e regras a serem seguidos na apreciação e alterações das propostas orçamentárias no Legislativo, a resolução $n^{\circ} 1$ de 2006-CN é a que permanece vigente até hoje $\mathrm{e}^{22}$. Após mais de 10 anos de sua aprovação, nenhuma outra nova

\footnotetext{
${ }^{22}$ A resolução do Congresso Nacional no 3 de 2015 incluiu alterações na resolução no 1 de $2006-C N$. Dentre as alterações mais importantes, encontra-se a inclusão da aprovação da regra da execução obrigatórias das emendas individuais orçamentárias (emendas impositivas), bem como o estabelecimento de um teto da receita a ser destinado para o atendimento das mesmas. Como o recorte deste trabalho limita-se até o ano
} 
resolução, com a proposta de uma nova estruturação dos trabalhos no interior do Legislativo foi aprovada. Abaixo, a Figura 5 apresenta um resumo com as principais alterações propostas por todas as resoluções que aqui foram retratas.

de 2010, não tratarei com maiores detalhes das alterações provocas pela resolução 1 de 2015-CN. Para mais informações acessar: http://www2.camara.leg.br/legin/fed/rescon/2015/resolucao-3-25-setembro-2015781582-publicacaooriginal-148198-pl.html 
Figura 5: Resumo das principais alterações aprovadas pelas Resoluções do Congresso Nacional

\begin{tabular}{|c|c|c|c|}
\hline Resolução & CMO & Emendas & Atribuições dos Relatores \\
\hline 1 de 1991 & $\begin{array}{l}\text {-Total de } 120 \text { membros: } 90 \text { Deputados e } 30 \text { Senadores. } \\
\text {-Responsabilidade de apreciar o PPA, a LDO e a LOA. }\end{array}$ & $\begin{array}{l}\text { - Compatíveis com o PPA e a LDO. } \\
\text {-Sem limites de quantidade e valores. }\end{array}$ & $\begin{array}{l}\text {-Definição do Parecer Preliminar. } \\
\text {-Apresentação de emendas sem restrições. } \\
\text {-Apreciação das emendas propostas. } \\
\text {-Escolha dos relatores setoriais. }\end{array}$ \\
\hline 1 de 1993 & $\begin{array}{l}\text {-Total de } 84 \text { membros: } 63 \text { Deputados e } 21 \text { Senadores. } \\
\text {-Responsabilidade de apreciar o PPA, a LDO e a LOA. }\end{array}$ & $\begin{array}{l}\text {-Define limites de quantidade para as } \\
\text { emendas individuais e coletivas. }\end{array}$ & -Não altera as atribuições dos relatores. \\
\hline 2 de 1995 & -Mantém a regra adotada anteriormente. & $\begin{array}{l}\text {-Diminui o limite de apresentação das } \\
\text { emendas individuais. } \\
\text {-Extingue as emendas partidárias e cria } \\
\text { as emendas regionais. } \\
\text {-Estabelece que o parecer preliminar } \\
\text { trará, anualmente, limite de valores } \\
\text { para as emendas individuais. }\end{array}$ & $\begin{array}{l}\text {-Definição de sete subcomissões temáticas. } \\
\text {-Vedado ao relator geral a apresentação de } \\
\text { emendas de despesas e proposição de novas } \\
\text { obras. } \\
\text {-Relator geral passa somente a propor emendas } \\
\text { de correção. } \\
\text {-Criação dos relatores Adjuntos. } \\
\text {-Produção do Parecer Preliminar. }\end{array}$ \\
\hline 1 de 2001 & $\begin{array}{l}\text {-Passa a ter um papel fiscalizador perante aos gastos do } \\
\text { Executivo e ao cumprimento da LOA. } \\
\text {-Criação de comitês de avaliação. } \\
\text {-Realização de Audiências Públicas. }\end{array}$ & $\begin{array}{l}\text {-Coloca restrições para a apresentação } \\
\text { de emendas de bancada. } \\
\text {-As demais regras são mantidas. }\end{array}$ & $\begin{array}{l}\text {-Extinção dos relatores adjuntos. } \\
\text {-Criação de } 10 \text { áreas temáticas para a avaliação } \\
\text { das matérias orçamentárias. } \\
\text {-Maior poder de apreciação e definição do } \\
\text { parecer preliminar para o relator geral. } \\
\text {-Manteve as restrições quanto a proposição de } \\
\text { emendas de receita. }\end{array}$ \\
\hline 1 de 2006 & $\begin{array}{l}\text {-Total de } 40 \text { membros: } 30 \text { Deputados e } 10 \text { Senadores. } \\
\text {-Adiciona a apreciação das Medidas Provisórias. } \\
\text {-Traz maiores detalhes quanto ao papel a ser } \\
\text { desempenhado por todos os membros da Comissão. }\end{array}$ & $\begin{array}{l}\text {-Aumenta as regras e altera a } \\
\text { quantidade de emendas coletivas. } \\
\text { Destaque para as emendas de Bancada. } \\
\text {-Aumenta a quantidade de emendas } \\
\text { individuais }\end{array}$ & $\begin{array}{l}\text {-Mantém as atribuições anteriores, contudo } \\
\text { define em maiores detalhes o papel de cada um } \\
\text { dos relatores. } \\
\text {-Define melhor as regras de escolha e ocupação } \\
\text { dos cargos das relatorias. }\end{array}$ \\
\hline
\end{tabular}

Fonte: Elaboração própria com base nas Resoluções do Congresso Nacional. 
Como foi possível de ver até aqui, desde que o Legislativo recuperou o poder de alterar o orçamento, muitas alterações e novas regras foram criadas com a finalidade de restringir e delimitar a participação dos parlamentares nessa esfera de atuação. O grande marco, sem dúvida, foi o escândalo dos anões do orçamento em 1993. A partir desse episódio as resoluções criadas e aqui elencadas tornaram mais claro e objetivo o modo como as alterações da peça orçamentária deveriam acontecer no interior do Legislativo.

Tais regras, por sua vez, também colocam em evidência que dificilmente os parlamentares conseguem atuar de maneira autônoma, ou seja, livre de constrangimentos no orçamento. Como as regras aqui mostraram, os parlamentares são impedidos ou não estão autorizados a realizar alterações fora das proposições e planos realizados pelo Executivo. Além da existência das regras e coordenadas estipuladas anualmente pela LDO, os pareceres preliminares elaborados pelos relatores gerais e setoriais reforçam ainda mais sob que circunstâncias não só o dinheiro deve ser alocado, como também determinam as circunstâncias nas quais será dada a participação dos parlamentares.

A certeza que fica é, portanto, a de que a participação do Legislativo, sobretudo a participação dos parlamentares, não acontece ou não é dada de forma livre. O Executivo consegue muito bem delimitar e coordenar a participação dos legisladores nessa esfera de atuação. Ainda que o Legislativo consiga e esteja autorizado a fazer modificações na peça orçamentária, essas alterações não acontecem à revelia e contra as vontades do Executivo 


\section{CAPÍTULO 2- Atuação individual ou partidária?}

A atuação dos parlamentares, bem como a estrutura dos trabalhos no interior do Congresso Brasileiro, não são mais, ou parecem não ser, a grande caixa preta a ser desvendada como era no início dos anos 90. Os trabalhos desenvolvidos nessa década e nos anos subsequentes quebraram importantes paradigmas acerca do comportamento dos parlamentares brasileiros e do funcionamento das instituições políticas. Não há dúvidas: a organização das atividades legislativas e o longo processo de apreciação até a tomada de decisões acerca das políticas é dado em termos partidários (DINIZ, 2005; FIGUEIREDO; LIMONGI, 1999; FREITAS, 2016; SANTOS, 2002).

Ainda que a adoção do sistema eleitoral de representação proporcional de lista aberta, bem como a adoção do presidencialismo como forma de governo, sejam frequentemente vistos como a fonte dos principais incentivos para uma atuação mais autônoma dos parlamentares e, consequentemente, como importantes fatores explicativos para a ausência de cooperação entre o Executivo e o Legislativo (LAMOUNIER, 1992; LINZ, 1991; MAINWARING, 1993), a centralização do poder decisório na figura do presidente e dos líderes partidários seria a responsável por gerar os incentivos contrários, proporcionando a coordenação das ações dos parlamentares e, ao mesmo tempo, induzindo a cooperação entre os poderes.

Desde o início até o final do processo de elaboração de políticas no interior do Legislativo brasileiro, parlamentares só conseguiriam atuar por intermédio de seus partidos políticos. Por controlar o acesso às comissões, por decidir a agenda de políticas a ser votada, por controlar o acesso a recursos e por conformar as diferentes preferências dos atores políticos, a melhor estratégia de atuação dos parlamentares brasileiros, ainda que estes estejam interessados em garantir seu sucesso eleitoral, é a de atuar por intermédio dos seus respectivos partidos.

Embora tenha sido dito aqui - e hoje esse não seja mais um ponto de discussão nos trabalhos que tratam do funcionamento e da organização dos trabalhos no interior do Congresso - que os partidos são o principal eixo estruturador dos trabalhos e da atuação coletiva dos parlamentares no interior da arena legislativa, haveria ainda, de acordo não só com alguns autores (AMES, 2003; PEREIRA; MUELLER, 2002, 2003, PEREIRA; RENNO, 2001, 2007), mas também com a própria mídia, um momento muito específico e importante do processo legislativo em que a atuação do parlamentar seria dada de 
maneira individual e livre dos constrangimentos impostos pelos partidos políticos: na elaboração do orçamento.

Tornou-se um verdadeiro lugar comum, argumentar que no momento da alteração do orçamento no interior da arena legislativa as famigeradas emendas individuais orçamentárias seriam as principais representantes da atuação auto interessada do parlamentar. Esse seria o momento em que os atores políticos não só não precisariam ou necessitariam da atuação coordenada com seus pares para realizar políticas de cunho clientelístico, como também seria o momento oportuno para que o Executivo se empenhasse na compra de apoio dos parlamentares.

No capítulo anterior esclareci como é dada a participação do Executivo e do Legislativo no orçamento brasileiro. Nesse capítulo, indo na contramão dos argumentos expostos acima, procuro construir o argumento de que até mesmo nesse momento, cujas regras poderiam favorecer a atuação individual, os parlamentares brasileiros consideram a melhor estratégia de atuação a de agir por intermédio de seus partidos políticos. Ainda que as emendas individuais sejam vistas como a principal ferramenta que o parlamentar tem disponível em mãos para fazer políticas diretamente para o seu eleitorado, a realização dessas políticas, ao contrário do que está estabelecido e posto pela literatura, não acontece sem a influência dos partidos políticos.

Dito isso, esse capítulo encontra-se dividido da seguinte forma: primeiro apresento uma breve revisão acerca das duas principais vertentes argumentativas mobilizadas na literatura para explicar o comportamento dos parlamentares em contextos decisórios. Em seguida exponho as evidências e argumentos quanto à atuação dos parlamentares no caso brasileiro, principalmente no que diz respeito à atuação no orçamento. E, por fim, apresento as hipóteses de trabalho com as quais lidarei, decorrentes da literatura aqui apresentada, e o universo de análise a ser explorado.

\section{Ação coletiva e atuação parlamentar: modelos explicação}

Não é estranho afirmar que parlamentares são indivíduos racionais que buscam maximizar suas preferências com vista a alcançar um objetivo bem definido: a reeleição (DOWNS, 1957). Contudo, nem sempre a tomada de decisões coletivas é tarefa fácil. Mesmo possuindo um objetivo idêntico, parlamentares não possuem as mesmas estratégias para alcançar seus propósitos. E dado que os trabalhos no interior do 
Legislativo são dirigidos pelo princípio majoritário, onde uma maioria deve tomar as decisões, como explicar a tomada de decisões coletivas e, consequentemente, a cooperação que deve existir no interior dessa arena, uma vez que os atores políticos estariam em constante conflito por não possuírem as mesmas preferências?

O economista Kenneth Joseph Arrow procurou responder a essa questão em seu teorema conhecido como "Teorema da Impossibilidade". Nesse teorema, o autor argumenta que seria impossível saber qual é o resultado da preferência da coletividade, mesmo que as preferências individuais sejam conhecidas. A simples agregação de preferências individuais não necessariamente resultaria em uma decisão coletiva estável. Olson (1965), refletindo principalmente sobre a dinâmica do funcionamento de grandes grupos, também atenta para essa questão. De acordo com o autor, mesmo que os indivíduos tenham preferências comuns, não necessariamente serão capazes de agir coletivamente sem a presença da figura do que ele denomina ser um "empreendedor", ou seja, sem a presença de alguém que coordene essas diferentes ações.

Baseados nessas questões e tendo como cenário de estudo o funcionamento do Congresso americano, dois grandes campos argumentativos são comumente mobilizados para explicar a tomada de decisões coletivas no interior do Legislativo: um primeiro modelo conhecido como distributivista, em que os incentivos oriundos da arena eleitoral seriam os responsáveis por modelar o comportamento dos atores na arena legislativa, e um segundo modelo conhecido como partidário, em que as regras e incentivos provindos do interior do próprio Legislativo moldariam o comportamento dos atores políticos, bem como explicariam a atuação dos parlamentares no interior de seus respectivos partidos políticos (BOWLER, 2002).

Nestes modelos, a atuação dos parlamentares é dada de forma diferente, ou pelo menos, sofre a influência de incentivos diferentes. Ainda que todos parlamentares busquem como fim em si a reeleição e que apliquem a mesma gama de estratégias, definidas por Müller e Strom (1999) como policy, office or vote, , o modo como essas estratégias são aplicadas varia de um modelo para o outro, sofrendo constrangimentos diferentes em razão da estrutura de organização dos trabalhos no interior da arena legislativa.

No primeiro desses modelos, o modelo distributivista, os parlamentares atuariam de forma mais individualizada devido aos incentivos provindos da arena eleitoral - disso decorre a definição do modelo como sendo de duas arenas - e as decisões coletivas, no 
interior da arena Legislativa, seriam tomadas graças a estrutura e modus operandi das instituições, que ao mesmo tempo em que garantiriam a realização de acordos entre parlamentares, também garantiriam aos mesmos o uso da estratégia de produção de políticas localistas com vistas ao alcance do sucesso eleitoral.

No segundo modelo, o modelo partidário, as ações dos parlamentares seriam moldadas de acordo com a organização dos trabalhos no interior do Legislativo que, por sua vez, seria inteiramente estruturado, em termos partidários. Nesse modelo de atuação o uso de qualquer estratégia pelo parlamentar teria, antes, que ser dada e pensada no interior dos partidos políticos, responsáveis também por organizar todo o processo de tomada de decisões.

Por fim, cabe aqui destacar que ambos os modelos que serão tratados adiante com mais cautela foram pensados tendo em vista mais um elemento: sistemas presidencialistas. $\mathrm{O}$ argumento comumente usado é o de que as decisões coletivas seriam ainda mais difíceis de serem tomadas nesses sistemas em que, ao contrário do parlamentarismo, carregaria consigo a característica principal de possuir a origem e sobrevivência independente dos dois principais poderes, Executivo e Legislativo e, dessa forma, ser marcado pela ausência de mecanismos de cooperação (LINZ, 1991).

Nesses sistemas, dado que presidentes e parlamentares são eleitos de forma diferente e, o principal, por eleitores diferentes - um nacional e outro local parlamentares encontrariam poucos incentivos para agir coletivamente e apoiar a agenda de políticas do presidente. Por possuírem preferências e interesses diferentes das do presidente, parlamentares responderiam aos incentivos do sistema e atuariam de forma individual na busca pela satisfação de seus interesses.

\subsection{Distributivismo e atuação individual}

O argumento que serve de alicerce para o modelo distributivista é o de que a arena eleitoral seria a fonte de explicação para o comportamento dos atores políticos na arena legislativa (CAIN; FEREJOHN; FIORINA, 1990; MAYHEW, 1974). De acordo com essa vertente, inteiramente pensada e formulada para explicar o comportamento dos parlamentares no interior do Congresso americano, os políticos atuariam de forma auto 
interessada no interior do Legislativo, onde concentrariam seus esforços na produção de políticas do tipo distributivista ${ }^{23}$ para seus redutos eleitorais.

Dada a característica do sistema eleitoral americano, em que os parlamentares são eleitos por distritos uninominais - o que significa também afirmar que a disputa pelo seu cargo ocorre no interior do distrito, onde na etapa eleitoral ele deve competir com outros candidatos pela conquista do cargo - a maior preocupação do político ao chegar na arena legislativa deve ser a de realizar ações e políticas que beneficiem seu eleitorado, uma vez que seu objetivo será o de disputar as eleições futuras com vistas alcançar a reeleição.

Por sua vez, a organização decentralizada dos trabalhos no interior do Legislativo, estruturado em cima de um sistema de comissões, auxiliaria os parlamentares na construção de uma conexão eleitoral com suas bases locais. As comissões americanas seriam o locus não só da atuação e do atendimento dos interesses desses parlamentares, bem como de todo o processo estruturador de tomada de decisões.

A primeira dessas esferas de atuação, qual seja, a da atuação individual e localista do parlamentar, funcionaria da seguinte forma: o eleitorado que importa para os parlamentares, aquele que os elege, porque circunscrito a distritos pequenos, tem preferências homogêneas e o político, ao identificar tais preferências, ocuparia a comissão com maior afinidade com os interesses dominantes de seu eleitorado. Assim, por exemplo, se o eleitorado de determinado distrito demanda políticas de saúde, o parlamentar eleito por aquele distrito ocupa a comissão de saúde para conseguir fazer políticas nesse âmbito e que possam, assim, atender aos interesses e demandas de seu eleitorado.

Por outro lado, indo para a segunda esfera de atuação, ocorreria no interior do Congresso um processo de logrolling ${ }^{24}$, onde os parlamentares pertencentes a diferentes comissões temáticas trocam apoio em plenário, permitindo não só que suas políticas de interesse sejam aprovadas, bem como que decisões coletivas sejam tomadas. Assim, parlamentares que pertencem a comissão A, por exemplo, votariam favoravelmente as políticas elaboradas pelos parlamentares da comissão B e vice-versa.

\footnotetext{
${ }^{23}$ Políticas distributivistas nas palavras dos autores Weingast, Shepsle e Johnsen podem ser definidas como: "By distributivism policies we mean those projects, programs, and grants that concentrate the benefitis in geographically specific constituencies, while spreading their costs across all constituencies through generalized taxation.(1981, p. 643)

${ }^{24}$ Shepsle e Weigast $(1987,1994)$ tratam melhor da questão do logrolling e do funcionamento das comissões no congresso norte-americano, dado a óptica do distributivismo. Essas questões não serão tratadas com mais detalhes neste trabalho, porque o que interessa, por ora, é o argumento central de tal modelo de atuação parlamentar e seus desdobramentos no Brasil.
} 
Nesse modelo, o processo de tomada de decisões seria descentralizado e marcado pela ausência do papel estruturador e organizador dos partidos políticos. O vital para a tomada de decisões seria o acordo selado entre os parlamentares que, por sua vez, estando motivados pelos resultados provindos da arena eleitoral, atuariam de maneira auto interessada na busca pela reeleição.

Atentando para o fato de o sistema político americano ser presidencialista e para o processo de tomada de decisões no interior do Legislativo, Cain, Ferejohn e Fiorina (1990) argumentam que quando representantes começam a agir de forma individualizada, ou como os autores colocam, como "free agentes", a coordenação da ação e tomada de decisões por parte do governo se torna mais difícil. E a explicação para isso é que nem sempre a produção da política que é boa para o parlamentar do ponto de vista do retorno eleitoral, será boa para a nação como um todo. Governo e parlamentares por serem eleitos de forma diferente, possuiriam interesses e estratégias de atuação diferente.

E se para o modelo partidário os partidos seriam o eixo estruturador capaz de garantir a tomada de decisões coletivas, no modelo distributivista os partidos políticos somente seriam vistos como agentes que são importantes para organizar e auxiliar os atores políticos nas eleições nacionais - dado que há a necessidade de organizar um eleitorado bem maior (MAYHEW, 1974). Uma vez que os eleitores respondem positivamente a seus candidatos garantindo-lhes o acesso ao interior do Legislativo, a produção de políticas no interior do Legislativo segue um caminho diferente. Parlamentares, interessados em manter seus cargos, atuam de maneira individual para garantir aquilo que seu eleitorado espera: a produção de bens localistas.

\subsection{Partidos políticos como agentes estruturantes da arena decisória}

$\mathrm{Na}$ vertente explicativa da atuação dos parlamentares no interior da arena legislativa os partidos, representados pelas figuras de seus líderes partidários, aparecem como os protagonistas da tomada de decisões coletivas em contextos democráticos (SCHATTSCHNEIDER, 1942). Eles conformam as distintas preferências dos atores políticos, indicam como cada parlamentar deve votar, negociam a agenda de políticas a ser votada, controlam o acesso a recursos, indicam as comissões nas quais os parlamentares farão parte e, talvez o mais importante para a sobrevivência de um sistema 
político: facilitam e diminuem os custos envolvidos nas negociações para a construção de maiorias (OWENS, 2003).

Sob a ótica da estrutura de organização das arenas legislativas, onde o imperativo majoritário dita a condução dos trabalhos, os partidos são elementos mais do que necessários para que decisões coletivas consigam ser tomadas. Sendo certo e definido que parlamentares não possuem as mesmas preferências, a tomada de decisões coletivas demanda um agente que seja capaz de agregar e conformar as distintas preferências envolvidas em uma única decisão. Olson (1965) já atentava para essa questão quando tratou das ações coletivas no interior dos grandes grupos. De acordo com o autor, não só a simples soma das preferências individuais dos atores torna impossível a tomada de decisões coletivas, como estas últimas só acontecem mediante a presença da figura de alguém que coordene as ações do grupo.

Caberia, portanto, aos partidos políticos e, sobretudo aos seus líderes partidários, a tarefa de agregar as diferentes posições políticas, bem como de elaborar as regras que regem e estruturam o processo legislativo e de tomada de decisões (ALDRICH, 1995; HAZAN, 2003). Dado que a ação coletiva é problemática, dado a ausência de incentivos para a cooperação entre os parlamentares, a solução para o problema da tomada de decisões e criação de um consenso residiria justamente na delegação do processo de organização dos trabalhos para uma autoridade central que seria nada mais, nada a menos do que o partido político. Nas palavras dos autores Cox e Mccubbins, considerados como os precursores dessa vertente explicativa:

"[...] parties are invented, structured, and restructured in order to solve a variety of collective dilemmas that legislator face. These "collective dilemmas" [...] are inherent in the drive to be reelected in a mass electorate and in the process of passing legislation by majority rule." (1993, p. 77).

Do ponto de vista do parlamentar e tendo em vista a organização dos trabalhos no interior da arena legislativa, atuar partidariamente parece ser a estratégia mais racional a ser adotada. Alicerçado sobre o postulado de Downs (1999) de que os atores políticos são indivíduos maximizadores de seus interesses e de que essa maximização depende diretamente da conquista do sucesso eleitoral, a melhor alternativa de ação que um parlamentar teria em mãos no interior da arena legislativa seria, sem sombra de dúvida, atuar por intermédio de seu respectivo partido político. Uma vez eleito, o parlamentar buscará ter acesso às ferramentas que atendam aos seus objetivos da melhor forma. $\mathrm{E}$, 
ainda que essas estratégias perpassem pelo interesse em realizar/ formular políticas, ter acesso a cargos e a recursos, os partidos políticos é que são os responsáveis não só por controlar, como também por organizar o acesso a essas ferramentas (THIES, 2002).

A grande questão, no entanto, no interior dessa vertente argumentativa foi a de lidar com as evidências de que os parlamentares corresponderiam de fato a esses incentivos voltados para uma atuação mais partidária. É nesse sentido que convencionouse usar, para identificar que os parlamentares de fato atuam por intermédio de seus partidos políticos, a disciplina partidária dos atores políticos em relação aos seus próprios partidos como indicador de que, de fato, os partidos políticos conseguiriam atuar como coordenadores das múltiplas preferências e interesses no interior do Congresso.

A métrica da disciplina partidária dos parlamentares em relação ao posicionamento de suas lideranças, ao contrário do que Krehbiel (1993) procurou argumentar, não significaria afirmar que os partidos reúnem indivíduos munidos das mesmas preferências. Pelo contrário. Significaria afirmar, como Laver e Schofield (1998, p. 22) colocaram, que partidos políticos são compostos por diversas facções que mediante a intensas negociações internas conseguem chegar a um acordo e tomar uma decisão. Nem sempre, contudo, é possível captar esses momentos de negociações. Na maioria das vezes eles ocorrem nos bastidores do cotidiano político. Mas ainda assim, haveria, de acordo com os autores, dois momentos muito específicos em que seria possível observar os parlamentares atuando enquanto um corpo partidário unitário.

O primeiro desses momentos, seria como citado anteriormente, as votações em conjunto. As altas taxas de disciplina partidária encontradas, sobretudo para os partidos europeus, seriam uma forte e primeira evidência de que a partir do momento em que os parlamentares delegam recursos e poderes de decisão aos partidos políticos, esses passam não só a controlar e modelar a agenda de trabalhos no legislativo, como também usam desse poder para aumentar a disciplina partidária. Uma vez que o controle da agenda legislativa é importante e dado que a arena legislativa é vista pelos parlamentares como o lugar para perseguirem seus objetivos, parlamentares teriam fortes incentivos para cooperar com os seus respectivos líderes partidários (GIANNETTI, 2005) e tal atitude é que resultaria em taxas elevadas de disciplina partidária.

O segundo momento, tão essencial quanto a disciplina partidária, em que a atuação partidária dos parlamentares se tornaria evidente seria no momento da entrada ou saída dos partidos políticos nas coalizões de governo. Não há como um partido entrar ou sair 
das coalizões de governo somente com parte de seus membros. Ou todos os membros de um mesmo partido aceitam a fazer parte do governo, ou o partido não entra para a coalizão.

Essa decisão, no entanto, não é tomada sem que ela antes seja negociada e acordada com todos os membros de um mesmo partido. Cada parlamentar tem seus motivos e justificativas para medir a quão custosa será essa decisão para os seus objetivos. E é nesse momento, que por mais uma vez, o líder do partido deve desempenhar sua função de conformar preferências para que uma decisão seja tomada. Seja essa decisão no sentido de apoiar o governo e arcar com os custos e benefícios envolvidos, seja para decidir que o partido não arcará com as consequências de se aliar ao governo.

É certo que grande parte dos estudos que aqui foram apontados lidaram com o funcionamento dos sistemas parlamentaristas europeus. Esses sistemas, por usa vez, dada a característica de fusão dos poderes Executivo e Legislativo, somada a possibilidade dissolução do governo, tenderiam a ter maiores incentivos para que os parlamentares atuassem partidariamente. A questão que fica, portanto é: no Brasil, com incentivos suficientes para uma atuação mais autônoma dos parlamentares como o sistema presidencialista e o sistema de representação proporcional de lista aberta, haveria evidências suficientes para assumir um comportamento partidário?

\section{O debate e evidências da atuação dos parlamentares no Brasil}

\subsection{Comportamento Partidário}

Iniciei esse capítulo com a afirmação, de acordo com os estudos desenvolvidos ainda na década de 90, de que os trabalhos no interior da arena legislativa, bem como o comportamento parlamentar seria dado em termos partidários. O Brasil, pósredemocratização, não fugiria a regra. A centralização do poder decisório com a transferência de poderes legislativos para a figura do presidente e de poder de agenda para os líderes partidários tornou a atuação partidária mais evidente no Brasil.

A definição da agenda política a ser votada e discutida, a indicação dos membros das comissões, bem como a indicação de voto passaram a ser definidas como atribuições das lideranças partidárias. E, como posto pela literatura aqui apresentada, uma das primeiras evidências de que os partidos se comportam como atores unitários na arena 
legislativa não está ausente no caso brasileiro. As altas taxas de disciplina partidária passaram a confirmar o que era esperado: os parlamentares brasileiros atuam por intermédio de seus partidos políticos. O Gráfico 3 abaixo apresenta a média da disciplina partidária dos onze maiores partidos políticos brasileiros, no geral, entre os anos de 1995 e 2010.

Gráfico 3: Média da disciplina partidária por ano (1995-2010 $)^{25}$

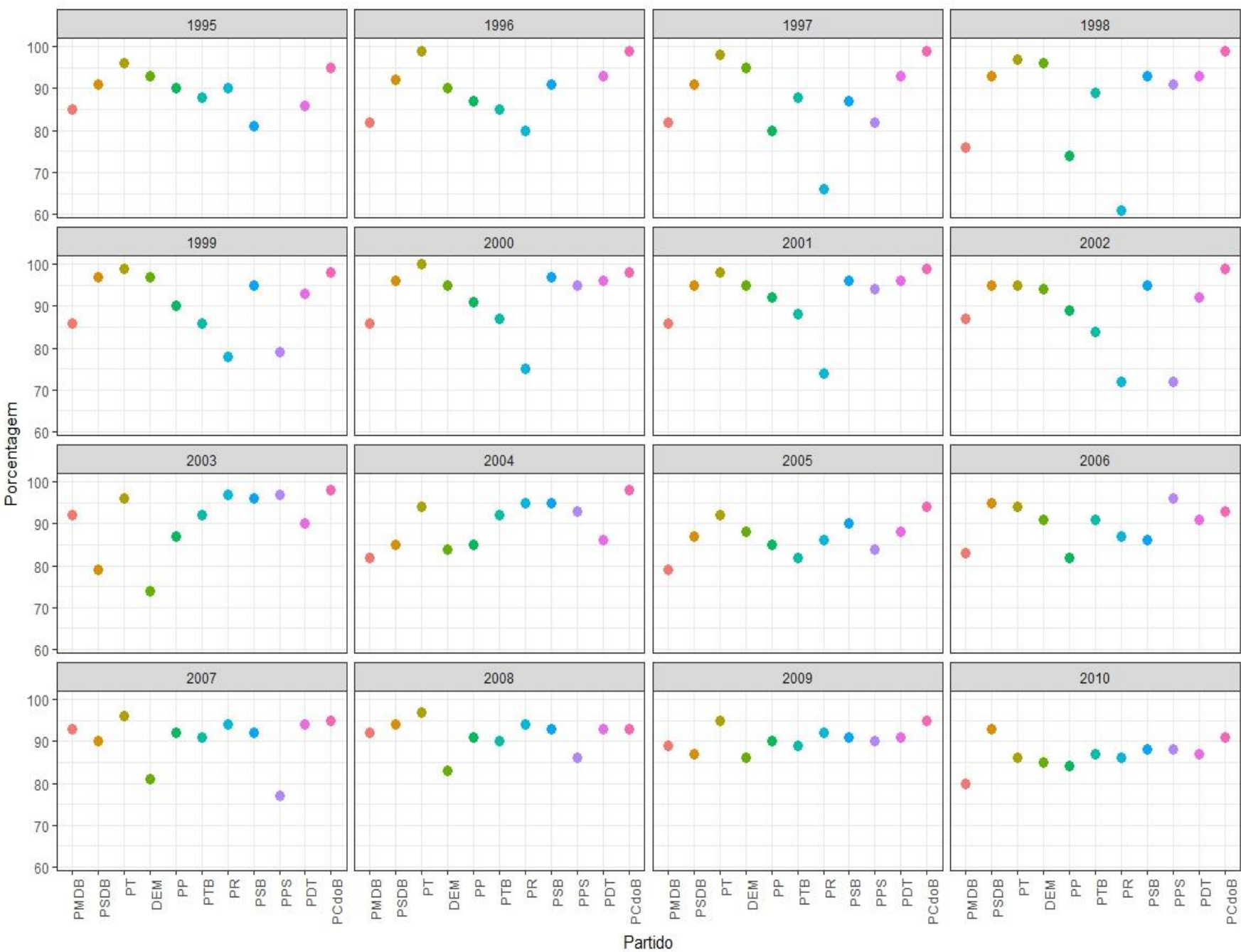

Fonte: Banco de Dados do Legislativo do Cebrap

Como fica evidente, desde as mudanças constitucionais ocorridas em 88 , todos os partidos nos anos que aqui serão analisados, apresentam disciplina partidária acima dos $70 \%$. A exceção à regra, talvez, seja o PR que em apenas dois anos da série temporal, nos

\footnotetext{
${ }^{25}$ Nas análises de todos os Gráficos as siglas partidárias do DEM serão remetidas também a antiga sigla PFL; as do PP também serão remetidas a sigla do PDS, as do PR serão remetidas ao PL, às do PPS serão remetidas a do antigo $\mathrm{PCB}$ e às do $\mathrm{PRB}$ serão remetidas ao PMR.
} 
anos de 1997 e 1998, apresentou uma taxa média de disciplina partidária de 66\% e 62\%, respectivamente. Mas o fato é que ao olharmos para a média da disciplina partidária do período todo, temos que nenhum partido apresenta uma taxa de disciplina inferior à $80 \%$.

As altas taxas de disciplina seriam uma primeira evidência ou indício, como Laver e Schofield (1998) Cox e Mccubbins (1993), Giannetti(2005), Hazan (2003) e Owens (2003) argumentaram para outros contextos, de que os partidos políticos no Brasil atuam como atores unitários. Seriam a evidência mais do que suficiente de que os líderes partidários conseguem conformar as diferentes preferências e opiniões internas em um partido no sentido da tomada de uma decisão única. Seriam a evidência mais do que suficiente de que os líderes partidários são capazes sim de coordenar a atuação de seus membros.

Indo além da evidência de que a indicação do voto dos líderes partidários é seguida pelos parlamentares, cabe ainda destacar outras tarefas diárias que os líderes partidários desempenham no interior do Congresso brasileiro. De acordo com o Regimento Interno da Câmara dos Deputados ${ }^{26}$ caberia aos líderes partidários a tarefa de selecionar seus membros para compor as comissões; de indicar os presidentes das comissões nas quais seu partido tem direito; de solicitar a verificação do quórum para validar as votações no interior das comissões; de reunir-se no Colégio de Líderes para decidir a pauta de votações a ser votada; de tomar a decisão de pedir urgência na apreciação e na tramitação de projetos e de indicar membros para as eleições da composição da Mesa Diretora.

No Brasil, sem ser a exceção, é possível afirmar que as regras que organizam o jogo no interior dessa arena induzem a ação partidária. Dadas as regras, a ação mais racional dos parlamentares é de agir por intermédio dos partidos. A estrutura dos trabalhos não dá margem para a atuação individual. Parlamentares, se desejam participar do jogo político, devem obrigatoriamente agir por intermédio dos seus partidos. Nas palavras de Figueiredo e Limongi: “[...] os parlamentares têm muito a ganhar quando são capazes de coordenar sua ação, isto é, quando resolvem o problema de ação coletiva que enfrentam. Reunir-se em torno de partidos é uma solução para esse problema."(1999, p. 35).

Esclarecida essa primeira evidência de que os parlamentares brasileiros atuariam de forma partidária, ainda há uma segunda evidência a ser apresentada. Como bem

\footnotetext{
${ }^{26}$ O Regimento Interno da Câmara dos Deputados pode ser consultado em: http://www2.camara.leg.br/atividade-legislativa/legislacao/Constituicoes_Brasileiras/regimento-internoda-camara-dos-deputados
} 
argumentaram Laver e Schofield (1998) uma segunda forma de olhar para os partidos políticos enquanto atores unitários é observar o comportamento desses partidos quando eles estão dentro ou fora da coalizão de governo. Uma vez que os partidos fazem parte do governo, espera-se não só que seus partidos ocupem cargos e acesso à recursos, mas que a vantagem em pertencer ao governo seja traduzida na forma de apoio político a agenda de políticas do Executivo.

Nesse sentido, Figueiredo e Limongi (1999) também foram os pioneiros ao mostrar evidências de que os partidos políticos, quando parte da coalizão, ofereceriam o aporte e o apoio necessário para aprovação da agenda de políticas vinda do Executivo. Mediante a apresentação de dados como a disciplina média dos partidos em relação ao líder do governo, bem como a taxa de aprovação dos projetos oriundos do Executivo, o que os autores buscam mostrar é que: uma vez que os partidos políticos aceitam a fazer parte do governo, eles assumem o compromisso de garantir no interior do Legislativo o apoio necessário dos parlamentares para a aprovação de uma agenda de políticas que é formada por todos os partidos que integram o governo.

Adiante apresento os dados para a disciplina média dos partidos em relação ao líder do governo para o total de 16 partidos. 
Gráfico 4: Disciplina partidária em relação ao líder do governo
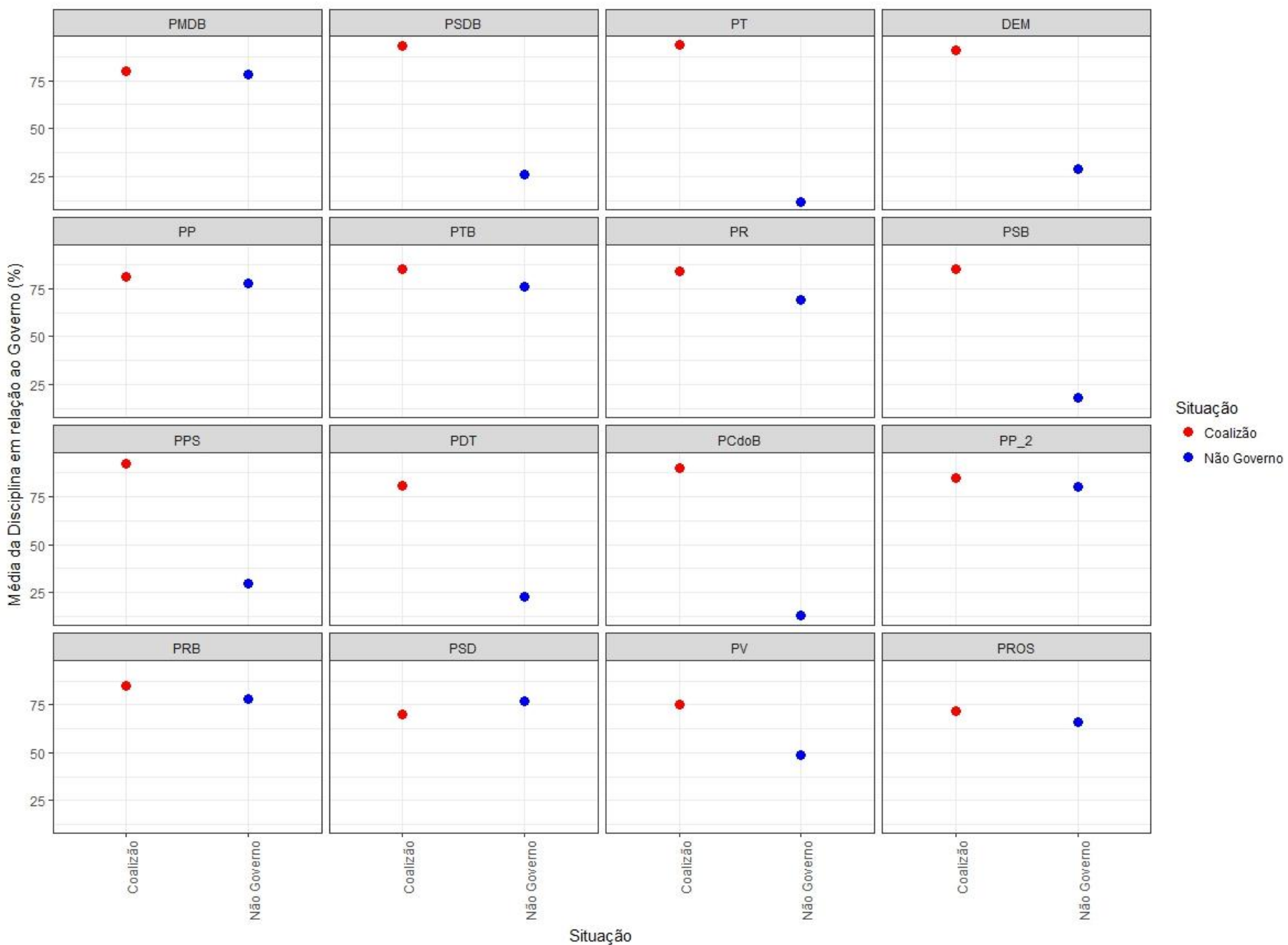

Fonte: Banco de Dados do Legislativo do Cebrap

Como fica evidente nos dados expostos acima, quando um partido decide fazer parte da coalizão de governo, a média da disciplina partidária em relação a indicação do líder do partido do presidente fica, em média, acima dos $70 \%$ para todos os casos. Ao passo que, quando um partido se posiciona fora da coalizão de governo e também decide por não o apoiar como é o caso do PSDB, PT, DEM, PSB, PPS, PDT, PCdoB e PV, a taxa média da disciplina partidária chega no máximo a atingir, em média, os patamares de 49\%. Os demais partidos como o PMDB, PP, PTB, PR, PP_2, PRB, PSD e PROS, quando não pertencem a coalizão, apresentam taxas média de disciplina partidária mais altas, justamente porque decidem apoiar o governo, mesmo estando fora dele.

Uma das outras formas que se convencionou usar para verificar a atuação partidária no Congresso brasileiro e, assim, comprovar que o sistema político não seria 
fadado à paralisia decisória, foi mediante a análise da taxa de sucesso do Executivo. Quando o Executivo detém uma taxa de sucesso alta, ou relativamente alta, o esperado é que essa taxa seja justamente explicada pelo apoio que ele recebe, como visto acima, dos parlamentares aliados aos partidos que compõe a sua base de governo. O Gráfico 5 adiante apresenta esses dados para os governos dos presidentes Fernando Henrique Cardoso (1995-2001) e Luiz Inácio Lula da Silva (2003-2010).

\section{Gráfico 5: Sucesso do governo}

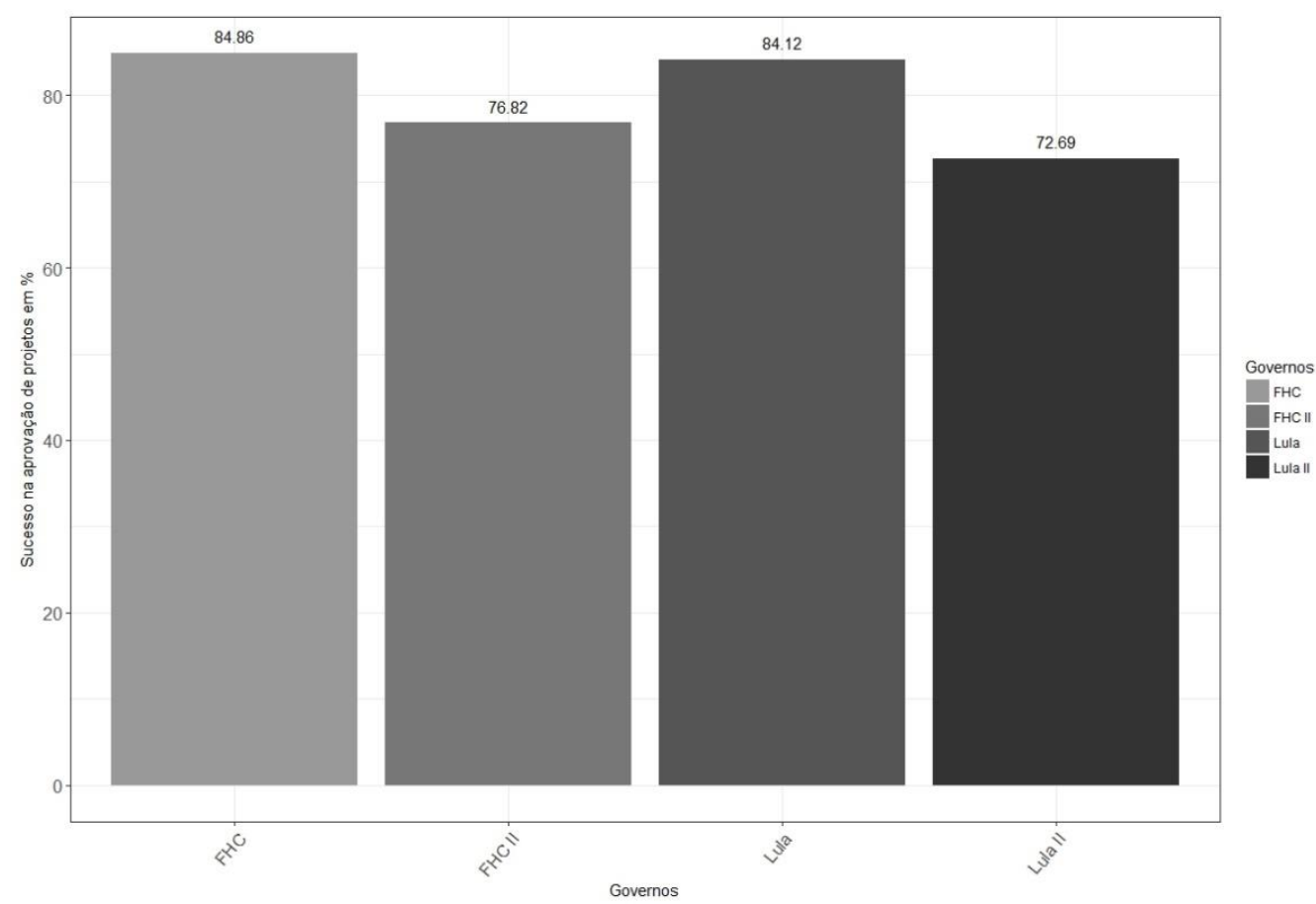

Fonte: Banco de Dados do Legislativo do Cebrap

Como o Gráfico 5 acima mostra, a taxa de sucesso do Executivo para todos os governos que serão aqui analisados ultrapassa a taxa de 70\%. Isso significa afirmar que, para os governos aqui analisados, o Executivo tem, em média $80 \%$ dos seus projetos apresentados aprovados. E esse sucesso só é garantido, uma vez que o Executivo possui no interior do Legislativo uma base de apoio construída em termos partidários.

Em trabalhos mais recentes Freitas (2016) e Junqueira (2015) - indo além das evidências apresentadas aqui e já expostas em outro momento por Figueiredo e Limongi (1999) - procuraram mostrar não só como os partidos atuam como atores unitários no interior do legislativo brasileiro, mas também como os parlamentares atuam por intermédio deles. Lidando com a questão do apoio que o Executivo recebe se sua base 
aliada, ou seja, dos parceiros da coalizão, Freitas (2016) demonstra como os partidos que integram a base aliada do governo são os responsáveis por, juntos, realizar a maioria das alterações legislativas realizadas no interior do Legislativo. Os dados que a autora apresenta trariam fortes evidências de que, para além do apoio ao Executivo ser dado em termos partidários, a construção da agenda de políticas é feita por todos os partidos que integram a coalizão de governo.

Junqueira (2015) ao analisar as alterações - medidas em dispositivos ${ }^{27}$ - das Propostas de Emendas à Constituição (PEC), minucia ainda mais a questão das alterações realizadas pelos partidos da coalizão e adiciona evidências fortes de que os partidos coordenam o processo de alterações de políticas no Legislativo. Olhando para as alterações que ocorrem tanto na Câmara dos Deputados, quanto no Senado, a autora não só mostra que os partidos que integram a base do governo é são os responsáveis por realizar a maioria das alterações às PECs, como também vai além e mostra que as alterações que um partido realiza na câmara dos deputados são mantidas pelo mesmo partido no interior do Senado.

A conclusão a que chego, após os dados e pesquisas aqui expostos, é, portanto, que os trabalhos no interior do Legislativo são organizados, sim, em termos partidários. E os parlamentares, percebendo como é dada tal organização, decidem atuar por intermédio de seus partidos políticos, por reconhecer ser essa a melhor estratégia de atuação para atingir seus objetivos tanto dentro, quanto fora da arena legislativa. Os partidos políticos no sistema presidencialista brasileiro atuariam, enfim, tanto na teoria, quanto na prática como agentes responsáveis por coordenar e organizar as preferências heterogêneas presentes no interior do processo legislativo, resolvendo, sobretudo, os dilemas postos pela necessidade da tomada de decisões coletivas em regimes democráticos.

Haveria, no entanto, como posto no início desse capítulo, uma etapa específica do processo legislativo em que a atuação dos parlamentares brasileiros seria estabelecida de maneira mais autônoma. Livre e independente da presença dos constrangimentos e ação coordenativa dos líderes partidários, os parlamentares brasileiros durante o processo de alteração da Lei Orçamentária Anual (LOA), atuariam de maneira auto interessada

\footnotetext{
${ }^{27}$ Seguindo a metodologia desenvolvida por Couto e Arantes (2009), em lugar de contabilizar o número de emendas aprovadas, Junqueira (2015) desagregou cada uma das propostas legislativas em unidades elementares, chamadas de dispositivos.
} 
correspondendo, acima de tudo, aos estímulos do sistema de representação proporcional de lista aberta e do presidencialismo. Adiante apresento o debate, acerca deste comportamento.

\subsection{Emendas individuais orçamentárias: a evidência contrária à coordenação partidária no Brasil?}

Os estudos e argumentos apresentados na seção anterior apontam que os trabalhos no interior do Congresso brasileiro funcionam de acordo com uma lógica partidária e que o Executivo brasileiro consegue, dessa forma, ter sucesso na aprovação de sua agenda de políticas. Ainda assim, a crença de que não é dessa forma que o sistema político brasileiro opera sobrevive em boa parte da mídia, da população e de alguns estudiosos (AMES, 2003; PEREIRA; MUELLER, 2002, 2003, PEREIRA; RENNO, 2001, 2007). Tais crenças, por sua vez, estariam alicerçadas, sobretudo, na participação dos parlamentares no processo orçamentário. As famigeradas emendas individuais alimentam esta concepção do funcionamento do sistema político na medida em que são postas por de trás das explicações para o sucesso do Executivo e da aparente estabilidade do processo decisório no Congresso.

Há boas razões para tanto. Como dito na introdução deste capítulo, as emendas individuais orçamentárias carregariam consigo uma peculiaridade importante dentro de todo o processo de organização dos trabalhos no interior da arena Legislativa: o momento de sua proposição seria um dos únicos momentos em que os parlamentares conseguem e podem de fato atuar livres de seus respectivos partidos políticos e da influência dos seus respectivos líderes partidários. É o momento em que - como era esperado pelos incentivos gerados pela adoção do sistema de representação proporcional de lista aberta, bem como do sistema presidencialista - o parlamentar conseguiria, de fato, atuar de maneira totalmente individualizada e propor as políticas que atendem os interesses de seu eleitorado sem precisar, no entanto, do apoio de seu partido para atuar de tal forma.

$\mathrm{O}$ argumento de que as emendas individuais orçamentárias estão por de trás da explicação para o funcionamento do sistema político brasileiro funciona, acima de tudo, sobre dois pontos de vista. Sob a ótica do Executivo, essas emendas funcionariam como a moeda de troca perfeita. Ao realizar liberação de uma emenda individual, o Executivo estaria comprando o apoio do parlamentar, tão vital para a aprovação de sua agenda de políticas (PEREIRA; MUELLER, 2002). Já do ponto de vista do parlamentar, a liberação 
dos recursos das emendas individuais em troca do seu apoio seria vista como a oportunidade tão desejada e perfeita de conseguir angariar recursos para os seus redutos eleitorais (AMES, 2003; PEREIRA; RENNO, 2001, 2007).

O fato é que ambos os lados da argumentação foram explorados por outros autores e estudos. Sob o ponto de vista do parlamentar ao fazer uso dessas emendas, seja para conquistar, seja para "premiar" seus redutos eleitorais, o que tem sido mostrado é que essas emendas não aumentariam a probabilidade do sucesso do parlamentar nas eleições seguintes (MESQUITA, 2008) e que, ao contrário do que era esperado, os parlamentares não destinam a maior parcela de seus recursos para os municípios em que eles obtiveram a maior quantidade de votos em eleições anteriores (FIRPO; PONCZEK; SANFELICE, 2015).

Não haveria um padrão específico na distribuição das emendas individuais. Esses recursos orçamentários propostos pelos parlamentares e que têm como destino os municípios brasileiros nem sempre são alocadas onde o parlamentar conquistou a maior quantidade de votos. A maioria dos municípios, por exemplo, incluindo também aqueles em que o parlamentar não recebeu nenhum voto, recebem, em média, apenas uma emenda e, acima de tudo, um valor muito pequeno em termos de recursos (MESQUITA et al., 2014).

Do ponto de vista da "compra" de apoio do Executivo, Figueiredo e Limongi (2008) mostraram empiricamente que as emendas individuais orçamentárias seriam liberadas tanto para os parlamentares que são disciplinados em relação ao governo parlamentares da coalizão - , quanto para os parlamentares que não são - parlamentares que não pertencem a base do governo. Expandindo a série temporal que os autores analisaram, apresento o Gráfico 6 abaixo como forma de corroborar ainda mais os achados e a argumentação dos autores. 


\section{Gráfico 6: Distribuição da disciplina partidária média em relação ao governo e a taxa de execução média das emendas por parlamentar (1995-2010)}

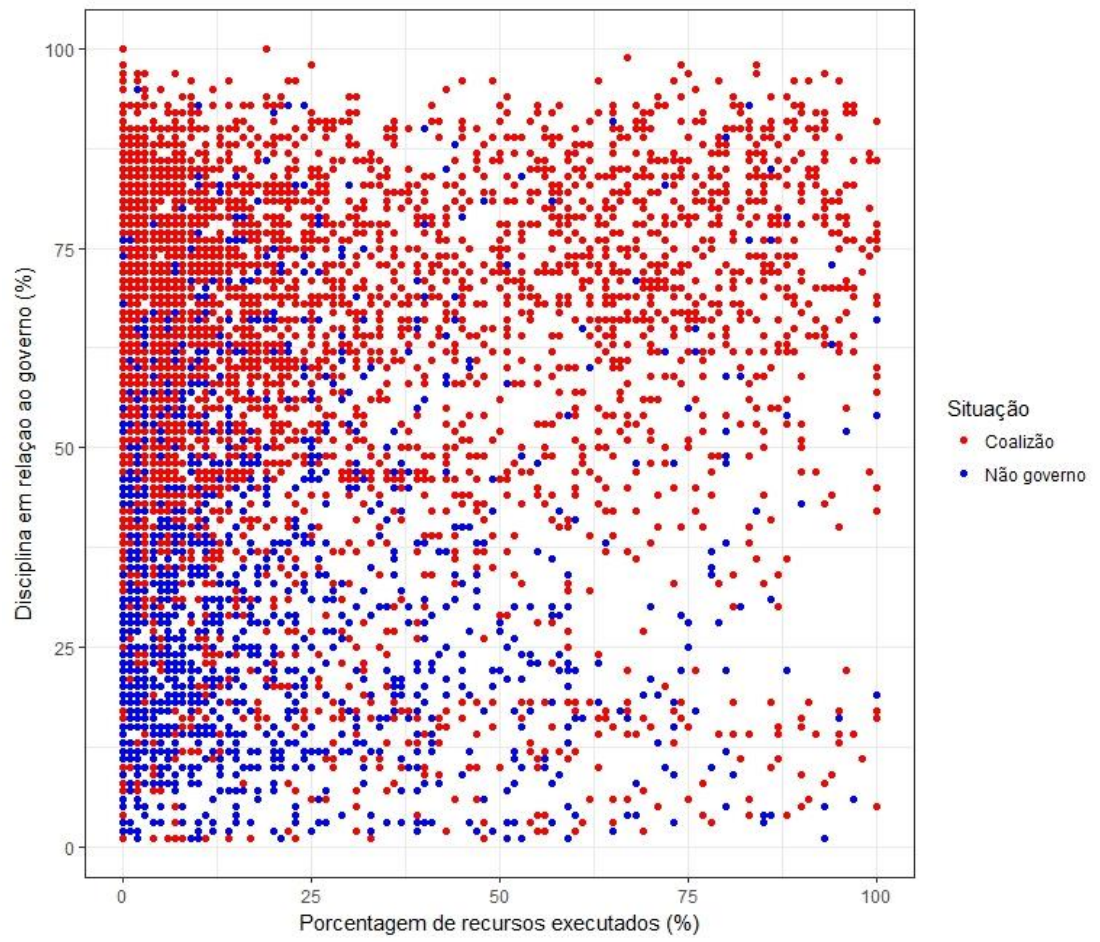

Fonte: Banco de dados do Legislativo do Cebrap, Banco de Dados Orçamento da União do Cebrap e SIGA Brasil

O Gráfico acima apresenta a distribuição da média da disciplina partidária em relação ao governo e da taxa de execução das emendas individuais dos deputados federais, divididos entre o pertencimento e o não pertencimento a coalizão de governo durante os anos de 1995 até 2010.Caso o Executivo usasse as emendas individuais orçamentárias como uma forma de comprar o apoio dos parlamentares, seria esperado, observar no Gráfico acima, que todos os parlamentares da coalizão que possuem médias altas de disciplina partidária tivessem recursos executados. Ao passo que o esperado também seria que nenhum dos parlamentares que não pertencem a coalizão e que possuem médias baixas de apoio ao governo não tivessem nenhuma emenda executada. Contudo, não é isso que o Gráfico nos mostra

As conclusões que são possíveis de ser tiradas a partir da análise desses dados é análoga a avaliação dos autores Figueiredo e Limongi (2008), ou seja, embora os parlamentares que pertencem a coalizão de governo tenham mais emendas executadas, não é possível afirmar que eles são os únicos a serem beneficiados. Como o próprio Gráfico mostra, os parlamentares que não pertencem ao governo apresentem médias mais 
baixas de disciplina em relação ao governo, mesmo assim, o Executivo executa parte de seus recursos. Outro ponto que ainda merece destaque com os dados apresentados é que há uma concentração de parlamentares que pertencem a coalizão com médias altas de disciplina partidária em relação ao governo, mas que possuem taxas bem baixas e próximas de zero quanto a execução das emendas individuais.

Era esperado que um acordo zelado nesses termos, ainda que seja plausível, seja muito instável. Por um lado, o Executivo, apesar de prometer liberar os recursos, pode não cumprir com a sua promessa após já ter recebido o apoio do parlamentar na aprovação de sua agenda de políticas. Do outro lado, o parlamentar pode escolher se comportar da mesma forma e, mesmo recebendo a liberação de seus recursos, pode decidir por não apoiar o governo. Não há, portanto, mecanismos institucionais críveis capazes de garantir que ambas as partes cumprirão a promessa de cooperação mútua.

Ainda, considerando que os parlamentares pertencentes à coalizão de governo têm mais recursos liberados com essas emendas, os achados de Vasselai e Mignozetti (2014, p. 843) ao realizarem testes estatísticos no sentido de comprovarem essa hipótese, chegam à conclusão que corrobora ainda mais o argumento apresentado acima, qual seja: não é possível afirmar que o Executivo faça uso dos recursos provenientes das emendas individuais orçamentárias para aprovar sua agenda de políticas. Seria preciso, na visão dos autores, encontrar outras evidências empíricas capazes de sustentar esse acordo.

A despeito das divergências e conclusões a que os estudos que aqui foram apresentados chegaram, um ponto comum merece desataque: a figura partido político como agente estruturante e coordenador da tomada de decisões desaparece. Seja para concordar ou discordar que esses recursos são vitais para a garantia do sucesso eleitoral do parlamentar e para o sucesso na aprovação da agenda do Executivo, as análises que aqui foram expostas não incluíram os partidos políticos nesse momento específico da participação do parlamentar na elaboração do orçamento brasileiro.

Para além disso, outro ponto que merece ser destacado é quanto a fase escolhida, pelos estudos aqui abordados, para analisar as emendas individuais. Todos os estudos se detiveram ao momento específico da liberação dos recursos, ou seja, da execução das emendas individuais orçamentárias. Tal momento com certeza é importante e carece de atenção, contudo o que busco argumentar é que olhar só para esse momento de todo um processo com várias etapas que envolve as emendas individuais orçamentárias não é 
suficiente para afirmar que os parlamentares atuam de maneira autônoma e livre da influência e constrangimentos de seu partido

O que proponho é dar um passo anterior e olhar para como realmente acontece o processo de elaboração dessas emendas. Acredito que o diagnóstico da ausência dos partidos nessa fase de participação dos parlamentares no orçamento está alicerçado, especialmente, sob o descarte de importantes etapas anteriores do processo de elaboração dessas emendas. Dito isso, meu principal objetivo nas exposições que virão adiante será o de construir teoricamente os argumentos e mostrar empiricamente as evidências de que os parlamentares agem partidariamente até mesmo nesse momento específico de sua atuação na alteração do orçamento.

\section{Construindo a coordenação partidária no orçamento}

\subsection{Uma construção teórica}

A participação dos parlamentares no orçamento brasileiro, a despeito das evidências apresentadas de que os trabalhos no interior do Legislativo são organizados em termos partidários, ainda é analisada sob a ótica de um comportamento individual e auto interessado. Conforme mostrado na seção anterior, as emendas individuais orçamentárias no Brasil parecem não corroborar o argumento de que o Executivo as utilizaria como "moeda" de troca para, de um lado, aprovar sua agenda de políticas e do outro para atender as demandas particularistas dos parlamentares. Haveria, portanto, indícios fortes para acreditar que a estabilidade do sistema político é garantida em termos partidários.

Contudo, estabelecido que os políticos são indivíduos racionais que atuam na busca pela maximização de seus interesses, qual seria a lógica da atuação desses parlamentares no momento da proposição dessas emendas individuais?

Ainda que o raciocínio dos parlamentares ao elaborarem essas emendas esteja vinculado ao atendimento de uma demanda e interesse por bens particularistas, para Figueiredo e Limongi (2005, 2008, 2009), dado o controle que o Executivo detém sobre o processo orçamentário, a lógica das emendas individuais estaria menos ligada a questões locais de atendimento de um eleitorado e mais alicerçada sobre às preferências e programas priorizados pelo governo (Figueiredo \& Limongi, 2005). 
Seguindo essa linha argumentativa, ao analisar as emendas individuais, seria preciso levar em consideração não só o destino, em termos de localidade e municípios de atendimento, mas também as restrições e o controle, aqui apresentados no capítulo 1, que o Executivo detém sobre a proposição dessas emendas. É certo que a Constituição prevê ao Executivo a prerrogativa exclusiva de iniciar legislação nas áreas de políticas importantes. Porém, mais importante que essas prerrogativas seriam as limitações impostas ao poder de emenda do Congresso brasileiro. (FIGUEIREDO; LIMONGI, 2008; SILVA, 2012).

No capítulo 1 apresentei as regras que os parlamentares devem obrigatoriamente seguir para conseguirem alterar a proposta da LOA, quando esta chega ao Congresso. Para além de se atentar aos limites de valores definidos e estabelecidos anualmente pelos pareceres preliminares, é importante que o parlamentar também fique atento aos programas e Ministérios para os quais irão apresentar suas emendas. A Figura 6 abaixo apresenta a síntese do processo de elaboração das emendas individuais orçamentárias.

\section{Figura 6: Destino que as Emendas Individuais devem seguir na elaboração da Lei Orçamentária Anual}

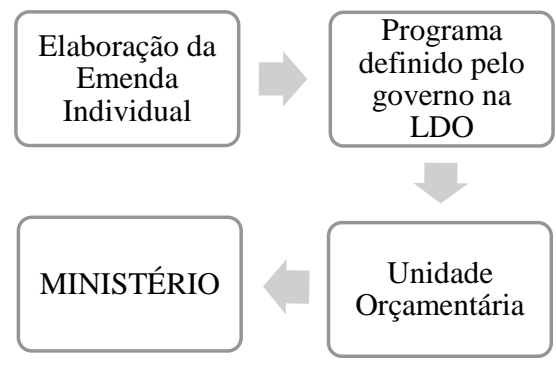

Fonte: Elaboração própria a partir das informações de Giacomoni (2012)

Em termos práticos, o controle do governo sobre o processo de elaboração de emendas ao projeto da LOA também está associado ao fato de que os parlamentares somente podem propor emendas em programas e Ministérios definidos, previamente na LDO, como prioritários pelo governo. E se, por sua vez, o parlamentar deseja ver sua emenda executada, é necessário que ele leve em consideração as prioridades e políticas definidas pelo governo dentro do processo orçamentário (FIGUEIREDO; LIMONGI, 2005).

Considerar o governo aqui, não significa considera-lo como um ator uno e centrado na figura do presidente e de seu partido. Definido que o sistema presidencialista brasileiro é de coalizão, tem-se que o Executivo seria constituído não só pelo partido do 
presidente, mas também pelos demais partidos que integram a base de apoio do governo e que, por definição, controlam pastas ministeriais (FIGUEIREDO, 2007). Sendo assim, todos os programas do governo são obrigatoriamente administrados e elaborados, política e financeiramente, por um dos Ministérios. Cada Ministro, por sua vez, é o responsável não só por elaborar as políticas públicas, como também por definir dentro do processo orçamentário a execução de recursos para essas políticas.

Por isso é que cabe ao parlamentar no momento de elaboração de uma emenda orçamentária não só a escolha de um programa, mas também a importante decisão sobre em qual Ministério ele deseja ter seus recursos alocados. A escolha de um Ministério deve levar em consideração as maiores chances de sucesso de uma política pública ser aplicada, pois sendo essa executada, há maiores chances de que a emenda individual de um parlamentar para essa política também seja efetuada.

Por conseguinte, tendo em vista o poder de controlar a elaboração e a execução orçamentária, os partidos que estão no interior do Executivo encontram-se em posição estratégica para conseguir a cooperação dos parlamentares, pois, como visto na seção anterior deste capítulo, para ser capaz de assumir um mandato junto ao eleitorado o curso de ação racional do parlamentar no interior do Congresso, deve ser o de agir por meio dos partidos, delegando poderes a seus respectivos líderes partidários que estão estritamente ligados aos seus respectivos Ministros (FIGUEIREDO; LIMONGI, 2002).

Negociar com os partidos, como visto, apresenta maiores vantagens para o Executivo, pois o apoio obtido é mais estável e previsível ao longo do tempo. Além do mais, tem como consequência a redução dos custos de uma transação em que incorreria na negociação de parlamentares tomados um a um. A sorte dos parlamentares situacionistas ou associados a coalizão também depende do sucesso do governo, pois integrar um governo bem-sucedido garante a moeda eleitoral para os parlamentares. A lógica proveniente da competição político-partidária na arena eleitoral não significa a oposição dos interesses individuais de cada parlamentar ao interesse do partido (Figueiredo e Limongi, 2008). Cabe aos próprios partidos políticos a tarefa de equilibrar as demandas de sua base eleitoral por bens particularistas e coletivos.

Nesse sentido, o argumento das emendas individuais como "moeda de troca" desconsidera, portanto, a realidade partidária que divide os parlamentares entre aqueles que apoiam e os que se opõe ao governo. Conforme os autores Figueiredo e Limongi: 
A conclusão a que chegamos é que a execução das emendas individuais deve ser tomada como parte de um pacote mais amplo envolvido nos acordos partidários que selam e soldam a participação dos partidos na coalizão que sustenta o governo. Isto é, parlamentares filiados a partidos que participam da base do governo votam favoravelmente à agenda do governo e têm taxas mais elevadas de liquidação de emendas porque participam do governo. Há uma causa comum: ser parte do governo. A imagem usada precisa ser retocada: não estamos diante de uma moeda de troca, e sim de duas faces da mesma moeda (FIGUEIREDO; LIMONGI, 2008b, p. 148, 150 e 151).

Ao liberar verbas definidas por meio das emendas individuais o Executivo estaria executando sua própria agenda da qual parte dos legisladores também estaria associada politicamente (FIGUEIREDO; LIMONGI, 2009). O presidencialismo brasileiro não possui um presidente que seja capaz de formular toda a agenda de políticas sozinho. Dessa forma, a coalizão formada por Ministros nomeados pelo presidente e que integram o governo também desempenha um papel significativo da decisão e na escolha dessa agenda. O resultado da formulação dessa agenda é um longo processo de negociação e barganha entre os partidos que integram o governo, pois nela o programa e os interesses eleitorais desses diferentes partidos têm que estar expressos mediante a figura do Ministro (Figueiredo e Limongi, 2008)

Ainda, é preciso notar que a distribuição de pastas ministeriais pelos partidos para a formação de um governo de coalizão envolve significativas concessões por parte do partido do presidente. Essas concessões acabam se tornando combinações entre benefícios diretos e posições políticas expressas pelas políticas preferidas dos partidos que integram a coalizão (FIGUEIREDO; LIMONGI, 2009). Dessa forma, o partido que assume um Ministério específico deve ser capaz de implantar com sucesso as políticas do governo e de competência do seu Ministério. E o primeiro passo na direção do sucesso dessas políticas está em conseguir o apoio de parlamentares no Legislativo para que essas propostas sejam aprovadas (Figueiredo e Limongi, 2008).

Enfim, o controle partidário sobre as pastas ministeriais se espelha no interior do próprio Legislativo e para que a coalizão seja de fato eficiente o governo junto a seus Ministros deve ser capaz de coordenar as ações dos dois ramos do poder (Figueiredo e Limongi, 2008). É por isso acredito que o destino das emendas individuais dentro do processo orçamentário também segue linhas partidárias.

Assim, seria razoável supor que ainda que os legisladores busquem benefícios concentrados para seu eleitorado, as regras do jogo decisório, na medida em que limitam 
as possibilidades de atuação dos parlamentares, podem tornar essa tarefa impossível. E, nesse caso, parlamentares terão que buscar outras formas de se diferenciar perante o eleitor. E o apoio à realização de políticas formuladas por uma coalizão pode ser uma dessas alternativas (CHEIBUB, 2007).

Dito isso, o que procuro mostrar adiante é que os parlamentares pertencentes as escolhem atuar por meio de seus partidos políticos quando apresentam emendas individuais ao orçamento. Não estou com isso negando que os atores políticos estejam interessados em fazer e realizar políticas para o seu eleitorado, muito pelo contrário. Acredito que parlamentares querem e devem realizar tais políticas, o eleitorado que os elegeu espera e pode esperar isso. Contudo, argumento que, para atingir esse fim, eles agem estrategicamente, por meio de seus respectivos partidos políticos.

Dentre os parlamentares que fazem parte da coalizão de governo, destinar recursos para o Ministério que seu partido controla evidenciaria não só o reconhecimento de que junto a seu partido sua emenda terá mais chances de ser executada, como também seria mais um dos indícios de que os parlamentares dão total apoio e suporte a política planejada pelo seu partido e, portanto, a agenda de agenda do governo.

Por outro lado, dentre os parlamentares que não integram a base de apoio ao governo, é razoável supor que estes, também interessados em garantir recursos para o seu eleitorado, irão destinar a maior parcela de seus recursos para os Ministérios com maiores chances de execução das emendas. Contudo o que buscarei mostrar é que até mesmo nesse momento os parlamentares que não pertencem ao governo agem partidariamente e concentram, juntos, a maior parcela de seus recursos em um mesmo Ministério.

\subsection{Uma construção empírica: hipóteses e universo de análise}

Com a finalidade de demonstrar as evidências de que há coordenação partidária no orçamento brasileiro serão realizadas análises empíricas acerca dos Ministérios de destino das emendas individuais orçamentárias aprovadas e executadas por deputados federais. Espera-se encontrar, mediante as análises, quatro tipos de comportamento, dividido de acordo com os dois principais momentos temporais dessas emendas.

O primeiro momento a ser analisado será a etapa de aprovação dessas emendas. E o primeiro comportamento esperado está relacionados aos parlamentares que pertencem 
a coalizão ${ }^{28}$ de governo. A expectativa com os resultados é a de que os parlamentares ligados ao governo destinem a maior parcela de recursos provenientes das emendas individuais para os Ministérios controlados pelos seus respectivos partidos. Assim, por exemplo, o esperado é que os parlamentares do partido A destinem a maioria de suas emendas individuais orçamentárias para os Ministérios controlados pelo partido A. Tal comportamento é esperado, tendo em vista que o parlamentar reconheceria que as maiores chances de ver sua emenda ser executada, depende justamente do apoio que ele dá a política formulada pelo partido no interior de um Ministério.

O segundo comportamento esperado diz respeito aos parlamentares que não pertencem ao governo. Como, por definição, os partidos aos quais eles estão vinculados não detém o controle sobre nenhuma pasta ministerial, a evidência esperada de que há alguma coordenação partidária é a de que os parlamentares, pertencentes a um mesmo partido, destinem a maior parcela de seus recursos para um mesmo Ministério. Caso esse padrão se confirme, teríamos evidências para argumentar que, até mesmo nos casos em que um partido não possui as vantagens de estar no governo, os parlamentares atuam unidos por um interesse em alguma política específica.

Caso os parlamentares não atuem partidariamente nesse momento, como parte da literatura aqui apresentada propõe, o esperado é que outros fatores influenciem a escolha do parlamentar ao destinar recursos para os Ministérios. Estando interessados somente no sucesso eleitoral e, consequentemente, na execução de suas emendas é possível esperar que os parlamentares destinem a maior parcela de seus recursos em emendas individuais para os Ministérios que dispõem de mais recursos para executar emendas ou que tenham algum vínculo maior com uma política que interesse e beneficie mais tanto o político em si, quanto a seu eleitorado.

Esclarecido esse primeiro momento de análise é possível extrair dele duas hipóteses principais:

$H_{1}$ : Parla mentares que pertencem a coalizão de governo destinam seus recursos para os Ministérios que seus respectivos partidos controlam. Enquanto que os

\footnotetext{
${ }^{28}$ No anexo 1 deste trabalho apresento todas as coalizões de governo, bem como seus respectivos partidos. Todos os parlamentares do universo de análise foram classificados como pertencentes ou não pertencentes a coalizão de governo ao longo da série temporal de 1995 e 2010 de acordo com os dados dessa Tabela.
} 
parlamentares da oposição, que pertencem a um mesmo partido, destinam juntos a maior parcela de seus recursos para um mesmo Ministério em específico;

$\mathrm{H}_{2}$ : Parlamentares tanto da coalizão, quanto da oposição destinam a maior parcela de seus recursos para os Ministérios que possuem mais recursos disponíveis para executar as emendas individuais orçamentárias;

A segunda etapa analisada será o momento da execução dessas emendas. Enquanto na aprovação a decisão de destinar uma emenda ou não para um Ministério em específico recaí sobre a figura do parlamentar, na execução essa decisão passa a ser do partido que controla o Ministério. Na busca pelas evidências de que há coordenação partidária até mesmo nessa etapa é esperado, em primeiro lugar, que os parlamentares da coalizão tenham mais recursos liberados que os parlamentares da oposição, dado que os partidos da coalizão são os que controlam pastas ministeriais.

Em um segundo momento espera-se que os Ministros decidam por executar mais recursos dos parlamentares que pertencem ao seu partido do que aos demais partidos parceiros da coalizão. Assim, por exemplo, suponha que o Ministério do partido X receba emendas dos parlamentares pertencentes ao partido X e D, ambos da coalizão. É esperado que no momento da execução das emendas individuais o Ministro X dê preferência para executar os recursos do parlamentar que também pertence ao partido $\mathrm{X}$, em detrimento de D.

Disso decorre duas outras hipóteses:

$H_{1}$ : Parlamentares da coalizão têm mais recursos executados do que os que não pertencem ao governo;

$\mathrm{H}_{2}$ : Parlamentares com a mesma filiação partidária que a do Ministro têm mais recursos executados do que os pertencentes a outros partidos da coalizão;

De modo a lançar luz sobre as hipóteses aqui apresentadas e sobre a distribuição das emendas individuais em si, o universo de análise utilizado é composto por todas as emendas individuais aprovadas e executadas dos deputados federais dos seguintes partidos: PMDB, PSDB, PT, DEM, PP, PTB, PR, PSB, PPS, PDT e PCdoB. O recorte e escolha desses partidos justifica-se, sobretudo, pelo fato de que esses são os 11 partidos 
que para além de existirem ao longo da série temporal aqui explorada, de 1995 a $2010^{29}$, ocuparam em algum momento do tempo pastas ministeriais. Também serão utilizados, para a finalidade das análises, todos os Ministérios que, de acordo com as definições da LDO, eram passíveis de receber emendas individuais.

O Gráfico 7 mostra o universo de análise dos parlamentares que aqui serão analisados. O Gráfico traz por ano, a quantidade de deputados federais, de acordo com o recorte de partidos aqui proposto, que apresentaram emendas, tendo em vista o limite de 513 deputados.

\section{Gráfico 7: Quantidade de Deputados Federais que apresentam emendas por ano} (1995-2010)

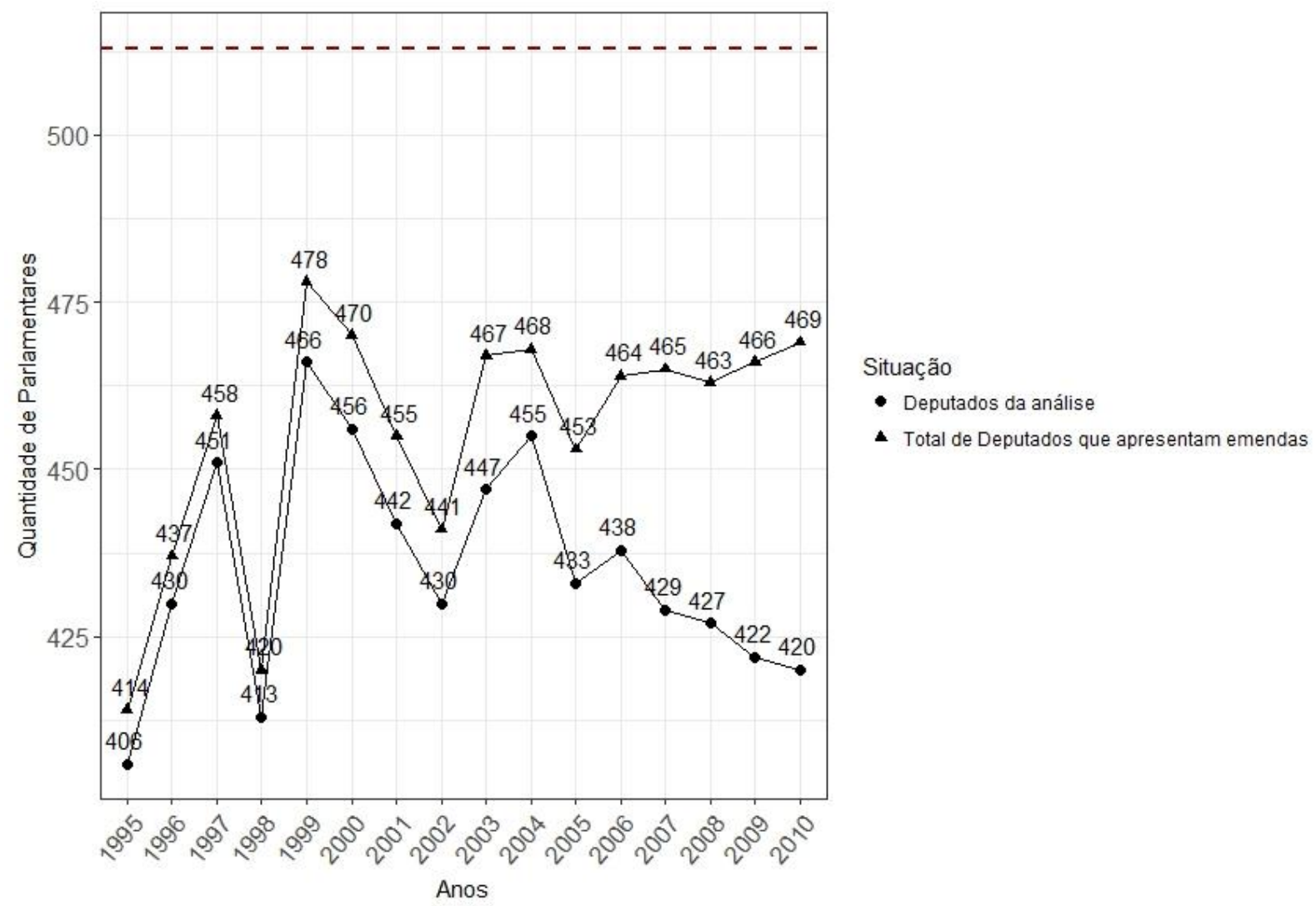

Fonte: Banco de Dados do Orçamento da União do Cebrap

Ao considerar o número de parlamentares que apresentam emendas por ano vê-se que a variação é bem pequena. A média para o período é de 456 deputados apresentando emendas. $\mathrm{O}$ ano em que há o menor número de parlamentares apresentando emendas é

\footnotetext{
${ }^{29}$ Os anos posteriores a 2010 não entrarão nas análises devido ao fato de o governo federal só liberar os bancos completos e finalizados dos dados do orçamento após 2 anos do término de sua execução.
} 
em 1995, ano este que também coincide, como dito no capítulo 1, com a adoção da Resolução do Congresso Nacional $N^{\circ} 1$ de 1995 que tinha por objetivo tornar as regras de apresentação das emendas mais rígidas para evitar práticas corruptas. Ao considerar o total de 513 deputados, ainda é possível perceber que, em média, 89\% dos parlamentares apresentam emendas ao orçamento.

Para o recorte aqui selecionado, em todos os anos mais de $90 \%$ dos deputados que apresentaram emendas serão cobertos pela amostra. Em média, somente $4 \%$ dos parlamentares não serão analisados. Passo agora para a apresentação dos dados no que se refere aos Ministérios nos quais há alocação de recursos provenientes de emendas individuais orçamentárias e que serão, portanto, aqui, objeto de análise.

\section{Gráfico 8: Quantidade de Ministérios que recebem emendas por ano (1995-2010)}

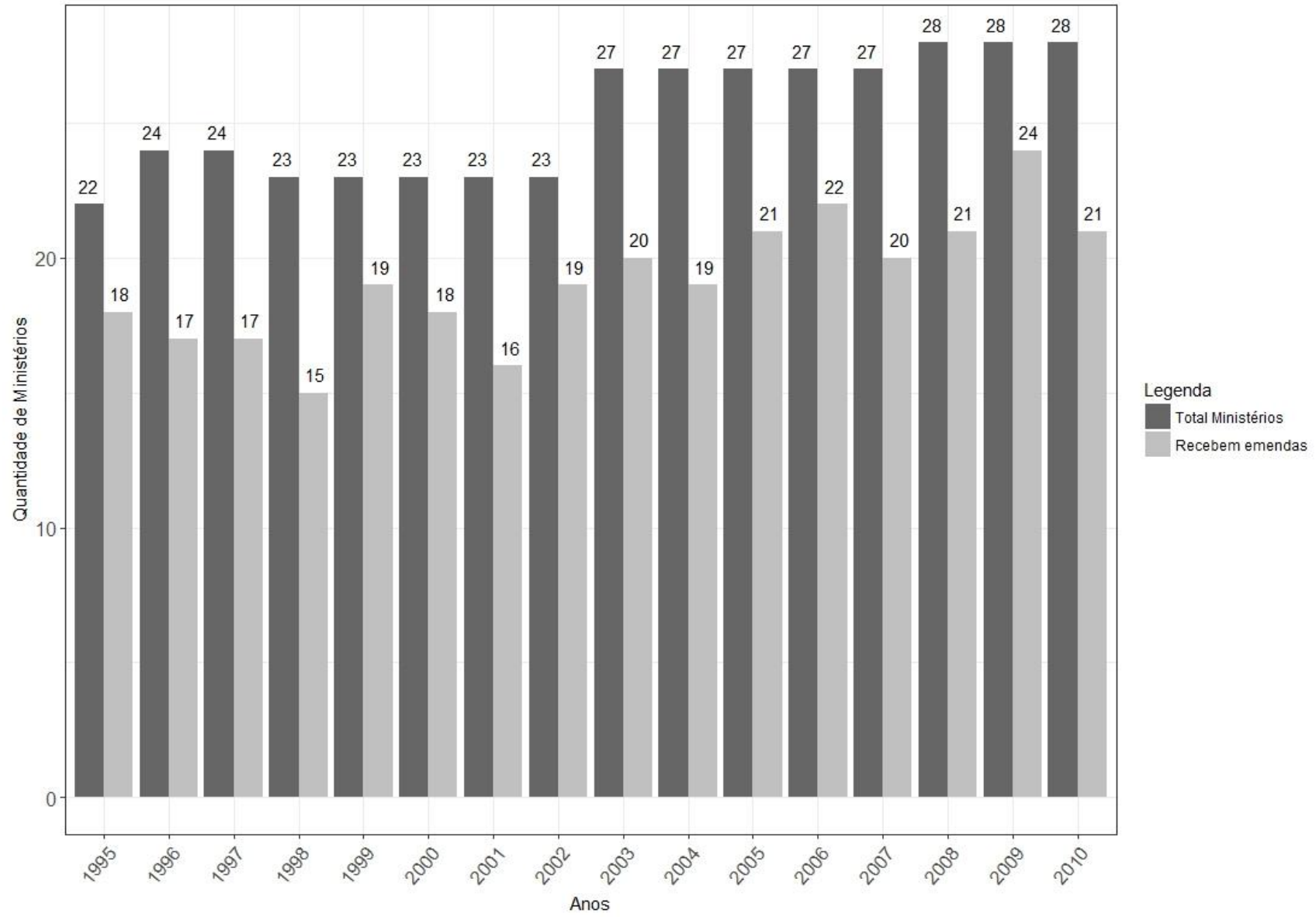

Fonte: Banco de Dados do Orçamento da União do Cebrap 
Serão analisados por ano, conforme os dados do Gráfico 8, todos os Ministérios que receberam emendas ${ }^{30}$. Como já ressaltado anteriormente, a LDO define quais serão os Ministérios que poderão receber recursos de emendas individuais orçamentárias. A barra mais escura indica o total de pastas ministeriais que existiam por ano e a barra mais clara indica a quantidade de Ministérios que não só receberam emendas, como também foram definidos pela LDO como pastas passíveis de receber esses recursos. Em todos os anos, todos os Ministérios definidos pela LDO como prioritários, sem exceção, receberam emendas.

Realizada a exposição desses dados, apresento adiante o universo completo da análise que será proveniente da junção das seguintes informações: quantidade deputados federais que apresentam emendas e quantidades de emendas apresentadas a um mesmo Ministérios. Tomarei aqui o ano de 1995 como exemplo para explicar a combinação construída. Em 1995 os parlamentares podiam distribuir, de acordo com as regras, os recursos disponíveis com essas emendas em um número máximo de 20 emendas. Essas emendas, por sua vez e como visto no Gráfico 8, também podiam ser alocadas em até 18 Ministérios diferentes. Pensando em apenas 1 parlamentar e usando a análise combinatória dada pela fórmula:

$$
C_{n, p}=\frac{n !}{p !(n-p) !}
$$

Onde:

n= número máximo de emendas apresentadas

p= Ministérios passíveis de receberem emendas

Temos para o ano de 1995 e, para um parlamentar em específico, um total de 190 possibilidades. Considerando que, nesse ano, 406 deputados que apresentaram emendas serão analisados, esse número seria equivalente a 787.014, ou seja, só para o ano de 1995 teríamos 77.140 combinações diferentes entre parlamentares, quantidades de emendas e Ministério de destino.

\footnotetext{
${ }^{30}$ O Ministério da Saúde, apesar de ser um dos Ministérios definidos como passíveis de receber emendas individuais orçamentárias, não será considerado e incluído totalmente no universo de análise. Isso se deve ao fato de que em alguns anos, como indicado na Tabela 2 ainda no capítulo 1 desse trabalho, a LDO define que os parlamentares são obrigados a destinar uma parcela fixa de seus recursos para esse Ministério. Portanto, nos anos de 2004, 2006 e 2007 o Ministério da Saúde foi desconsiderado das análises.
} 
Contudo, acontece que alguns parlamentares concentram suas emendas em Ministérios específicos e isso diminui o número de combinações em si. Um parlamentar pode, por exemplo, destinar todos os seus recursos para um mesmo Ministério e, assim, escolher somente 1 dentre suas combinações possíveis. A Tabela 3 abaixo, portanto, apresenta o número de combinações entre parlamentares, emendas e Ministérios que serão aqui analisados por ano.

Tabela 3: Quantidade de combinações entre deputados federais e destino das emendas para Ministérios

\begin{tabular}{|cc|}
\hline Ano & Quantidade \\
\hline \hline 1995 & 1.488 \\
1996 & 1.604 \\
1997 & 1.846 \\
1998 & 1.662 \\
1999 & 2.106 \\
2000 & 2.138 \\
2001 & 2.016 \\
2002 & 1.587 \\
2003 & 2.189 \\
2004 & 2.588 \\
2005 & 2.644 \\
2006 & 2.522 \\
2007 & 3.127 \\
2008 & 3.128 \\
2009 & 3.398 \\
2010 & 3.164 \\
\hline \hline Total & 37.207 \\
\hline
\end{tabular}

Fonte: Banco de Dados do Orçamento da União do Cebrap

Tomando novamente o ano de 1995 como exemplo, serão analisadas 1.488 combinações entre parlamentares e emendas destinadas para Ministérios. O que significa afirmar que para esse ano há 1.488 combinações diferentes entre as unidades que serão aqui analisadas. Incluindo os demais anos a serem analisados, o número total de combinações, conforme a Tabela 3 apresenta, a serem analisados será de 37.207.

Adiante, no próximo capítulo, passarei as análises e exploração das hipóteses que aqui foram apresentadas, juntamente tendo como base os argumentos e dados aqui expostos. 


\section{CAPÍTULO 3 - Política Ministerial}

Parlamentares atuam partidariamente no interior do Legislativo brasileiro. É através dessa atuação que eles conseguem não só realizar suas tarefas no interior dessa arena, como também, perseguir seus objetivos eleitorais. Parlamentares são atores racionais que estão sempre em busca da maximização de seus interesses. O modo como os trabalhos são organizados no interior do Legislativo, onde o imperativo majoritário é que dita as regras, não deixa dúvidas: agir partidariamente é a melhor estratégia que eles podem adotar para atingir seus objetivos, quaisquer sejam eles.

Ainda que o interesse dos parlamentares seja dado tendo em vista seu sucesso eleitoral e que, portanto, o atendimento desse interesse perpasse pela necessidade de conquistar seu eleitorado com políticas localistas, os parlamentares reconhecem que sem o partido, essa tarefa torna-se quase que impossível. Seja mediante a conquista de um cargo, seja pelo interesse genuíno em realizar políticas, seja pelo ensejo de conseguir recursos, seja qual for a razão, o fato é que parlamentares não podem obter seus objetivos prioritários sem os seus respectivos partidos. Dito de forma mais direta: atuar por intermédio dos partidos é a regra dominante.

No caso das emendas individuais orçamentárias, a história parece não ser diferente. Tradicionalmente essas emendas são vistas como a oportunidade perfeita que o parlamentar tem de concentrar recursos e bens particularistas em seus redutos eleitorais com vistas a "premiar", recompensar e até mesmo conquistar o voto de seus eleitores. Não discordo aqui da ideia e do argumento de que essas emendas são usadas para levar políticas e recursos para os eleitores. Uma vez que candidatos são eleitos, os eleitores não esperam outra coisa: demandam por políticas que atendam aos seus interesses.

O que procuro mostrar, no entanto, é que o parlamentar que decide usar suas emendas para concentrar benefícios em seus redutos eleitorais não faz essa escolha sem estar submetido a restrições. No momento de propor uma emeda não é só o cálculo do sucesso eleitoral em si que importa. Para que de fato os recursos de sua emenda atinjam seus objetivos eleitoreiros é preciso que o parlamentar leve em consideração as melhores opções disponíveis para ver sua emenda executada.

Sendo assim, o que mostrarei adiante é que os parlamentares tanto da coalizão de governo, quanto os parlamentares que não pertencem ao governo adotam uma estratégia partidária para alocar seus recursos. Enquanto os parlamentares da coalizão buscam 
concentrar seus recursos nas pastas ministeriais controladas pelo seu respectivo partido, os parlamentares que não pertencem a coalizão, mas que pertencem a um mesmo partido, buscam concentrar seus recursos em um mesmo ministério.

De modo tornar a exposição das evidências encontradas mais clara, apresentarei os dados divididos em dois grandes blocos de análise começando pelos dados das emendas individuais aprovadas. Realizada essa exposição, passarei para a apresentação dos dados das emendas executadas. Nessas duas partes, distingo os parlamentares de acordo com o seu pertencimento ou não à coalizão de governo.

\section{Emendas individuais aprovadas}

Nessa primeira etapa, o universo de análise a ser trabalhado, como apresentado no capítulo anterior, contará com todas as emendas individuais, aprovadas e destinadas para um mesmo ministério, de todos os parlamentares dos onze maiores partidos que pertenceram e ou não à base aliada do governo entre os anos de 1995 e $2010^{31}$. Assim, por exemplo, na apresentação dos dados a seguir será possível observar o comportamento dos parlamentares do PT quando estes estavam situados na coalizão de governo e quando estavam fora da base aliada.

Realizados esses esclarecimentos iniciais, essa seção terá como objetivo apresentar evidências empíricas favoráveis e contrárias às duas primeiras hipóteses de trabalho já apresentadas:

$H_{1}$ : Parlamentares que pertencem à coalizão de governo destinam seus recursos para os ministérios controlados por seus respectivos partidos. Enquanto que os parlamentares que estão fora do governo destinam a maior parcela de seus recursos para um mesmo ministério;

$\mathrm{H}_{2}$ : Parlamentares tanto da coalizão, quanto da oposição destinam a maior parcela de seus recursos para os ministérios que possuem mais recursos disponíveis para executar as emendas individuais orçamentárias;

\footnotetext{
${ }^{31}$ Não analisarei aqui o comportamento de um mesmo parlamentar em específico quando este está situado na coalizão de governo ou quando está situado fora da base aliada. A análise dos parlamentares será feita de um modo geral, ou seja, sem identificar os parlamentares por nome, somente pelo partido ao qual pertencem nas duas situações em que serão analisadas.
} 


\subsection{Comportamento partidário dos parlamentares da coalizão}

O primeiro passo das análises consiste na apresentação de dados descritivos que procuram mostrar se de fato os parlamentares pertencentes à coalizão destinam a maior parcela de seus recursos para os ministérios controlados por seus respectivos partidos. As principais variáveis usadas para demonstrar tal relação são:

1. Porcentagem de recursos: média da porcentagem de recursos, em relação ao total de recursos, que os parlamentares apresentaram em emendas individuais para os ministérios habilitados a receber emendas;

2. Mesmo Partido: Variável dummy que indica se o parlamentar pertence (igual a 1) ou não pertence (igual a 0) ao mesmo partido que controla a respectiva pasta ministerial para qual destinou recursos.

A primeira tarefa para verificar se os parlamentares de fato destinam a maior parcela dos recursos disponíveis das emendas individuais para os ministérios controlados pelos seus respectivos partidos foi observar o montante, em média, que cada deputado individualmente procurou enviar para esses ministérios. O Gráfico 9 abaixo apresenta a média por governo da parcela de recursos com emendas individuais que cada parlamentar destinou para os ministérios controlados pelos seus respectivos partidos e para os demais ministérios. 
Gráfico 9: Média da porcentagem de recursos que os parlamentares destinaram aos ministérios, por governo

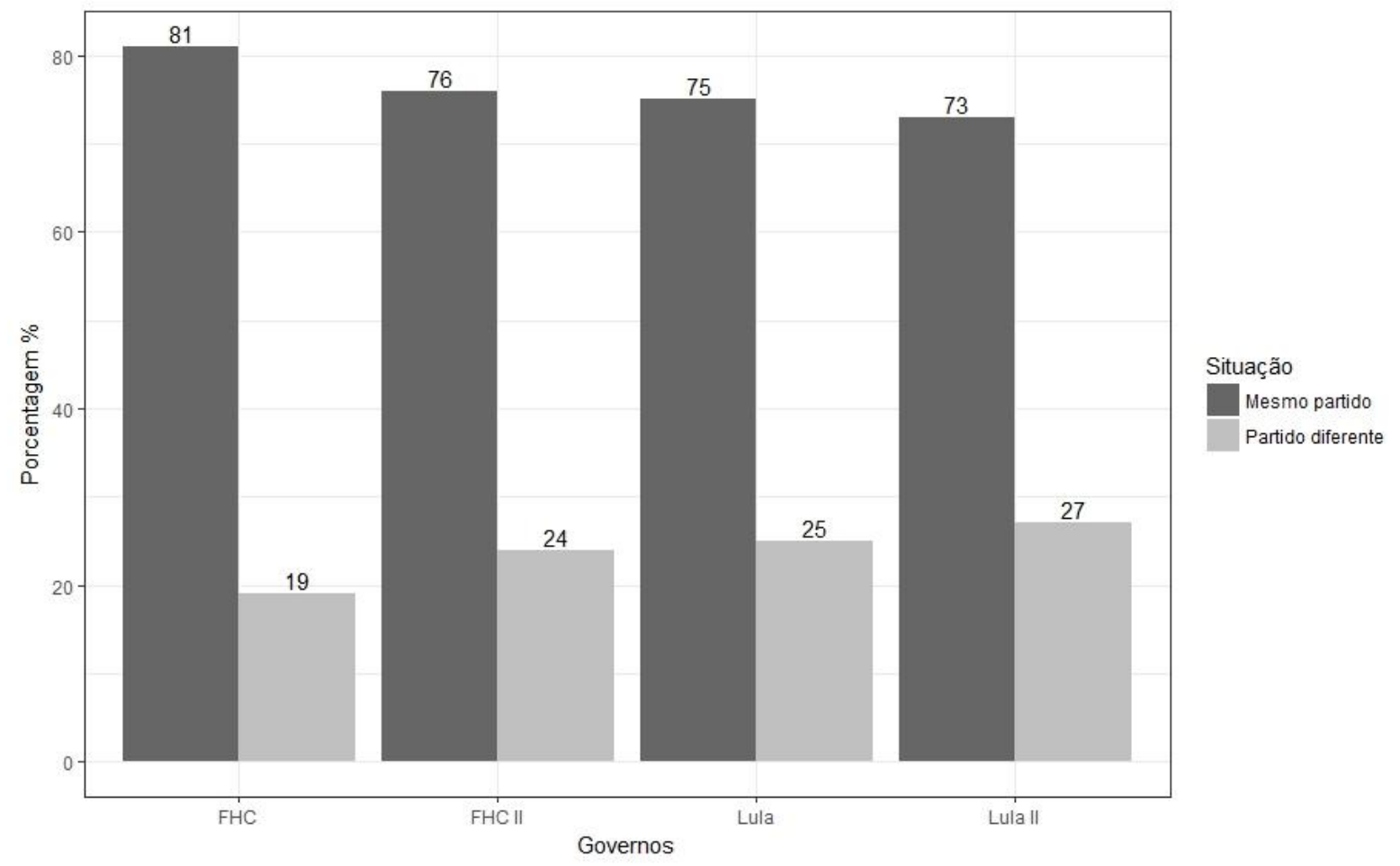

Fonte: Banco de dados do Orçamento da União do Cebrap e Siga Brasil

Como é possível observar, durante o primeiro mandato do presidente Fernando Henrique Cardoso (1995-1998), a média de recursos que os parlamentares pertencentes à base do governo destinaram para os ministérios controlados pelos seus respectivos partidos foi de $81 \%$. Isto é, cada parlamentar, em média, destinou $81 \%$ dos seus recursos disponíveis em emendas individuais orçamentárias para os ministérios controlados pelo partido ao qual pertenciam. Em média $19 \%$ dos recursos foram destinados para ministérios, controlados por outros partidos. Durante o segundo mandado de FHC o mesmo padrão se repete, sendo que a média de recursos destinados para os ministérios de mesmo partido passa a ser de $76 \%$ e para outros ministérios de $24 \%$.

Durante o primeiro e o segundo mandato do presidente Luiz Inácio Lula da Silva é possível observar o mesmo padrão. Entre os anos de 2003 e 2006 a média de recursos que cada parlamentar destinou para os ministérios controlados pelos seus respectivos partidos foi de $75 \%$, contra $25 \%$ que foram destinados, em média, para ministérios de partidos diferentes. No segundo mandado esses números sofrem uma pequena queda: os parlamentares destinaram, em média, $73 \%$ da parcela de seus recursos para os ministérios controlados pelos seus respectivos partidos, ao passo que os ministérios controlados por partidos diferentes receberam $27 \%$. 
Essa seria uma primeira evidência da estratégia perseguida pelos parlamentares no momento de sua atuação mais individual dentro do Congresso. Mesmo quando livres das amarras partidárias, parlamentares recorrem a seus partidos. De maneira resumida, o Gráfico 9 acima mostra que os parlamentares procuram destinar a maior parcela de seus recursos com emendas individuais para os ministérios controlados por seus respectivos partidos.

Adiante, o Gráfico 10 mostra como os parlamentares de cada um dos partidos da base do governo distribuíram suas parcelas de recursos de acordo com o controle dos ministérios. Seria possível esperar um comportamento diferente dos deputados de acordo com o partido político? Seria possível observar esse comportamento em todos os partidos ou somente em alguns deles?

\section{Gráfico 10: Distribuição da parcela de recursos para os ministérios de acordo com os partidos políticos (1995-2010)}

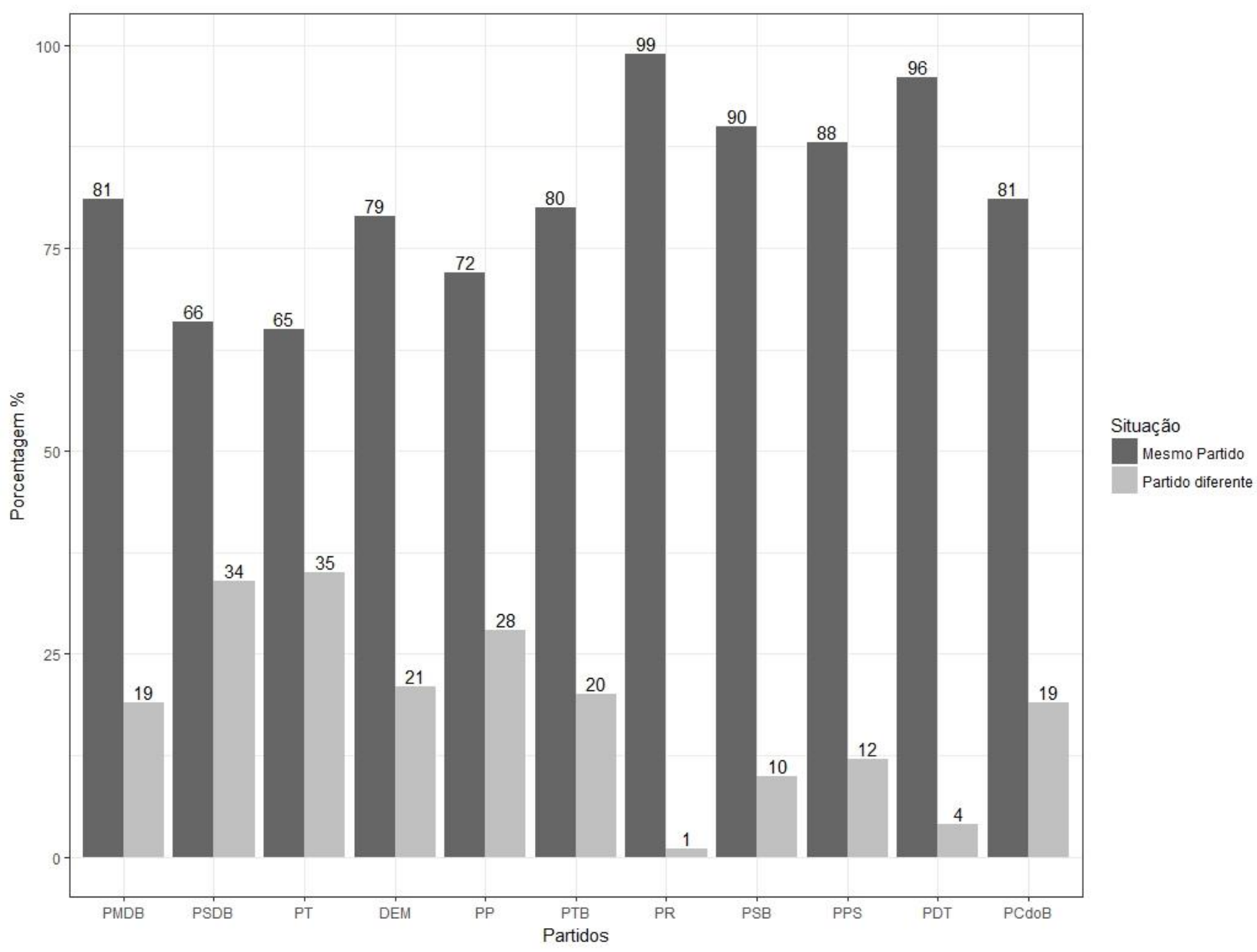

Fonte: Banco de dados do Orçamento da União do Cebrap e Siga Brasil 
Os dados apresentados no Gráfico 10 não deixam dúvidas: destinar a maior parcela de seus recursos para os ministérios controlados pelos mesmos partidos parece ser uma estratégia adotada pela maioria dos parlamentares que compõem a base do governo. Os casos que mais chamam a atenção, sem dúvida, são os do PR, o do PDT e o do PSB. Nesses partidos os parlamentares destinam, em média, mais de $90 \%$ dos seus recursos para os ministérios controlados pelos seus respectivos ministérios.

Entre os partidos em que os parlamentares destinam mais de $80 \%$, em média, de seus recursos para os ministérios controlados pelos seus respectivos partidos estão: o PCdoB, o PMDB, o PPS e o PTB. Na faixa dos 70\% têm-se ainda o DEM com uma média de $79 \%$, e o PP com $72 \%$. Os únicos partidos que ficam mais abaixo da média geral que é de $85 \%$, são os parlamentares do PT e do PSDB. Enquanto os paramentares do PT destinam, em média, $65 \%$ dos seus recursos para os ministérios controlados pelo seu próprio partido, a média dos parlamentares do PSDB é bem próxima a essa e atinge os $66 \%$.

Todos os parlamentares e partidos analisados aqui nessa seção tem algo em comum: todos eles, em algum momento do tempo, pertenceram à coalizão de governo e tiveram seus respectivos partidos a frente de alguma pasta ministerial. E os dados aqui apresentados mostram evidências fortes de que, conforme apontado ainda Capítulo 2, os parlamentares que estão situados na base do governo reconhecem que apoiar a agenda de política dos seus próprios partidos a frente de pastas ministeriais não significa, necessariamente, a oposição aos seus interesses. Parlamentares ao destinarem a maior parcela de seus recursos para os ministérios controlados pelos seus respectivos partidos estão ao mesmo tempo não só dando apoio financeiro às políticas formuladas pelo seu partido, como também, buscam maximizar suas chances de ver sua política concretizada.

De acordo com a hipótese levantada, portanto, os dados apresentados mostram evidências de que os parlamentares da coalizão atuam partidariamente na alocação de seus recursos. Contudo, é preciso verificar se esse comportamento se mantém quando esses mesmos partidos não estão situados na base aliada do governo. É preciso olhar o comportamento dos parlamentares no momento em que seus respectivos partidos não possuíam pastas ministeriais e que, por isso, não estavam presentes na coalizão de governo. 


\subsection{Comportamento partidário dos parlamentares fora do governo}

Diferente dos dados que foram apresentados na seção anterior, cuja principal variável mobilizada para explicar o comportamento partidário dos parlamentares situados na base do governo foi justamente pertencer ou não ao mesmo partido do ministro, o comportamento dos parlamentares que estão situados fora do governo não pode ser explicado pela mesma lógica. Por não pertencerem a um partido que ocupa uma pasta ministerial - principal característica que os define como sendo não pertencentes à base aliada do governo - seria possível pensar que as motivações para atuar partidariamente diminuem.

Uma vez que o partido não controla nenhum ministério e, decorrente disso, acesso a recursos, é racional supor que os parlamentares que não pertencem ao governo decidam por alocar suas emendas levando em consideração única e exclusivamente seus cálculos eleitorais. Nesse cenário seria possível, portanto, observar que o parlamentar destine seus recursos para os ministérios que possuem quantidade maior de recursos disponíveis para serem gastos com a liberação de emendas individuais.

Como uma primeira tentativa de mapear a alocação dos recursos das emendas individuais entre os parlamentares que não pertencem à base do governo serão mobilizadas aqui duas principais variáveis:

1. Porcentagem de recursos: novamente será utilizada a média da porcentagem de recursos, em relação ao total de recursos, que os parlamentares apresentaram em emendas individuais para os ministérios passíveis de receberem emendas;

2. Ministério específico: Variável dummy que indica se a maioria dos recursos estão alocados em um único ministério (quando um ministério recebe $50 \%+1 \%$ dos recursos em emendas individuais de um mesmo parlamentar ele ganha o número 1 , caso contrário 0$)$.

Adiante apresento o Gráfico 11 como resultado dessa primeira análise exploratória do comportamento dos parlamentares quando eles estão situados fora do governo. Como será possível observar, há um padrão na alocação das emendas desses parlamentares: eles alocam a maior parcela de seus recursos em um ministério específico. 
Gráfico 11: Média de recursos que os parlamentares destinaram para um único ministério, por governo

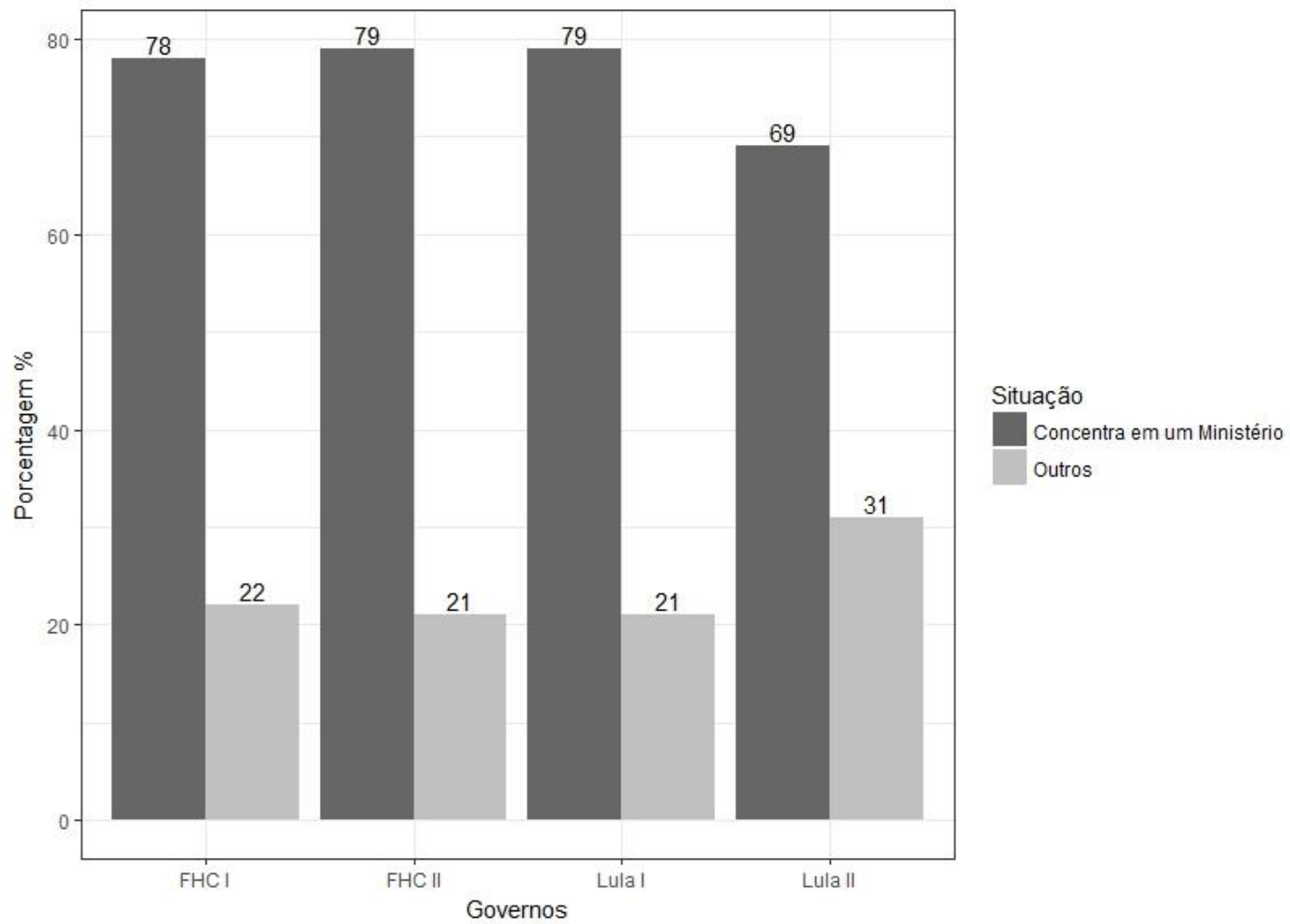

Fonte: Banco de dados do Orçamento da União do Cebrap e Siga Brasil

Durante o primeiro mandato do presidente Fernando Henrique Cardoso (19951998), a média de recursos que os parlamentares que não pertence à base do governo destinaram para um ministério em específico foi de $78 \%$. Em média $22 \%$ dos recursos foram destinados para outros ministérios. Durante o segundo mandado de FHC o mesmo padrão se repete, sendo que a média de recursos destinados para um único ministério passa a ser de $79 \%$ e para outros ministérios de $21 \%$.

$\mathrm{O}$ mesmo pode ser observado durante o primeiro e o segundo mandato do presidente Luiz Inácio Lula da Silva. Ainda entre os anos de 2003 e 2006 a média de recursos que cada parlamentar destinou para um ministério específico foi de $79 \%$, contra $21 \%$ que foram destinados, em média, para outros ministérios. No segundo mandado esses números sofrem alterações: os parlamentares destinaram, em média, $69 \%$ da parcela de seus recursos para um mesmo ministério, ao passo que os demais ministérios receberam em média $31 \%$.

Em um primeiro olhar, esses dados podem parecer estranhos. Considerando que os parlamentares esperam sempre ver suas emendas executadas para, assim, angariarem recursos para seus redutos eleitorais, seria esperado que eles destinassem seus recursos 
para mais ministérios, para aumentar as chances de ter sua emenda executada. Adiante, com o Gráfico 12, eu procuro mostrar que esses dados, no entanto, não soam de forma tão estranha assim.

\section{Gráfico 12: Distribuição da parcela de recursos para os ministérios de acordo com os partidos políticos não pertencentes à coalizão“ (1995-2010)}

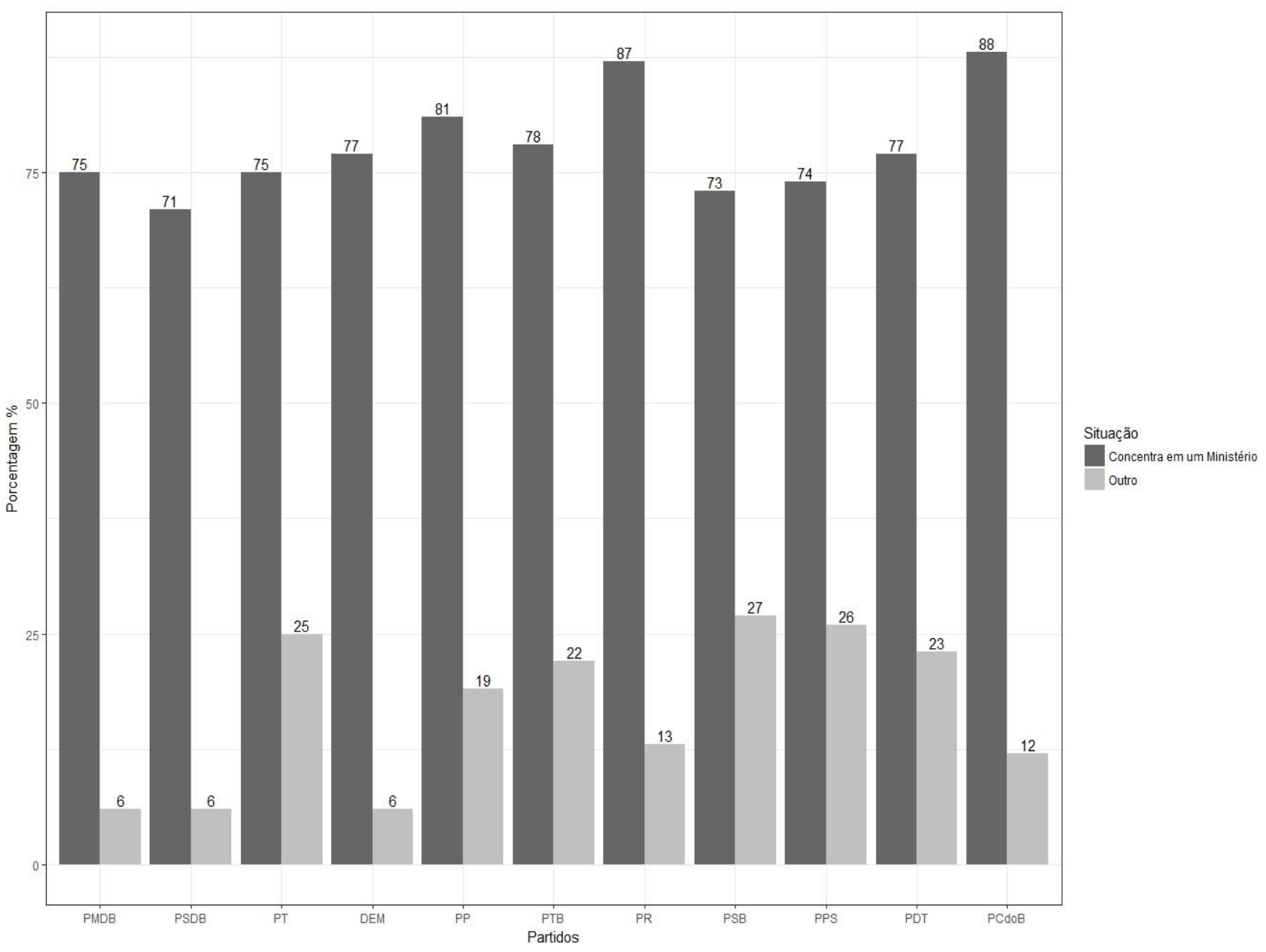

Fonte: Banco de dados do Orçamento da União do Cebrap e Siga Brasil

O que o Gráfico acima mostra é que os parlamentares, quando pertencentes a um mesmo partido, destinam em média a maior parcela de seus recursos para um mesmo ministério. Os casos que mais chamam a atenção são os do PCdoB, do PR e PP. Em todos esses partidos os parlamentares destinam, em média, mais de $80 \%$ dos recursos de suas emendas individuais para um ministério específico. Todos os demais partidos PMDB, PSDB, PT, DEM, PTB, PSB e PDT, uma vez fora do governo, também buscam concentrar seus recursos, mas não de forma tão acentuada. 
Ainda assim, não é possível afirmar que este seja um comportamento partidário. Seguindo os comentários críticos de Krehbiel (1993), o fato de os parlamentares de um mesmo partido concentrarem recursos em um único ministério não é suficiente para demonstrar a ação partidária. Poderíamos estar diante de um caso em que que a melhor estratégia para ver suas emendas executadas é a mesma para todos. Assim, todos os parlamentares, independente do partido no qual pertencem, poderiam concentrar suas emendas nos ministérios que detêm, por exemplo, mais recursos disponíveis para executá-las. A lógica adotada pelo parlamentar poderia ser: quanto mais recursos um ministério tem, mais chances de uma emenda ser executada e, assim, conseguir os recursos para a sua base eleitoral.

Contudo, esse não é exatamente o que os dados mostram. Como mencionado ainda no Capítulo 1 deste trabalho, as verbas que os Ministérios possuem para executar as emendas são provenientes do Grupo de Natureza das Despesas (GND) de Investimentos. O que eu procuro argumentar e expor é que os parlamentares que não pertencem ao governo para além de levarem em consideração, no cálculo da alocação de seus recursos, os Ministérios que detém mais dinheiro disponível para executar as emendas, ou seja mais recursos no GND de investimentos, também atuam sob uma lógica partidária.

Os Gráficos 13 e 14, adiante, devem ser interpretados da seguinte forma: no eixo y estão os cinco maiores partidos que não pertenciam à base do governo durante os anos de governo de FHC e Lula. O eixo x representa a porcentagem média de recursos que os parlamentares de um mesmo partido destinaram para um ministério. As barras identificadas pelas cores que vão de A até E representam, do maior para o menor, os cinco Ministérios $^{32}$ que mais receberam recursos sob a rubrica de "Investimentos"33.

Nota-se também, que nos anos em que não há nenhuma barra para um partido específico, significa que esse partido pertencia a base do governo. Somente há barras preenchidas para os partidos que, naquele ano em específico, não pertenciam a coalizão de governo.

\footnotetext{
${ }^{32}$ No anexo 2 podem ser visualizadas as tabelas que identificam os cinco Ministérios por ano que mais receberam recursos sob a rubrica de investimentos

${ }^{33}$ No anexo 3 apresento os mesmos dados em um Gráfico com os onze partidos que são aqui analisados quando na oposição e a destinação de seus recursos para os cinco ministérios que mais possuem recursos sob a rubrica de investimentos.
} 
Gráfico 13: Destino das emendas individuais dos parlamentares que não pertencem a base do governo de acordo com os Ministérios que mais detém recursos em Investimentos (1995-2002)

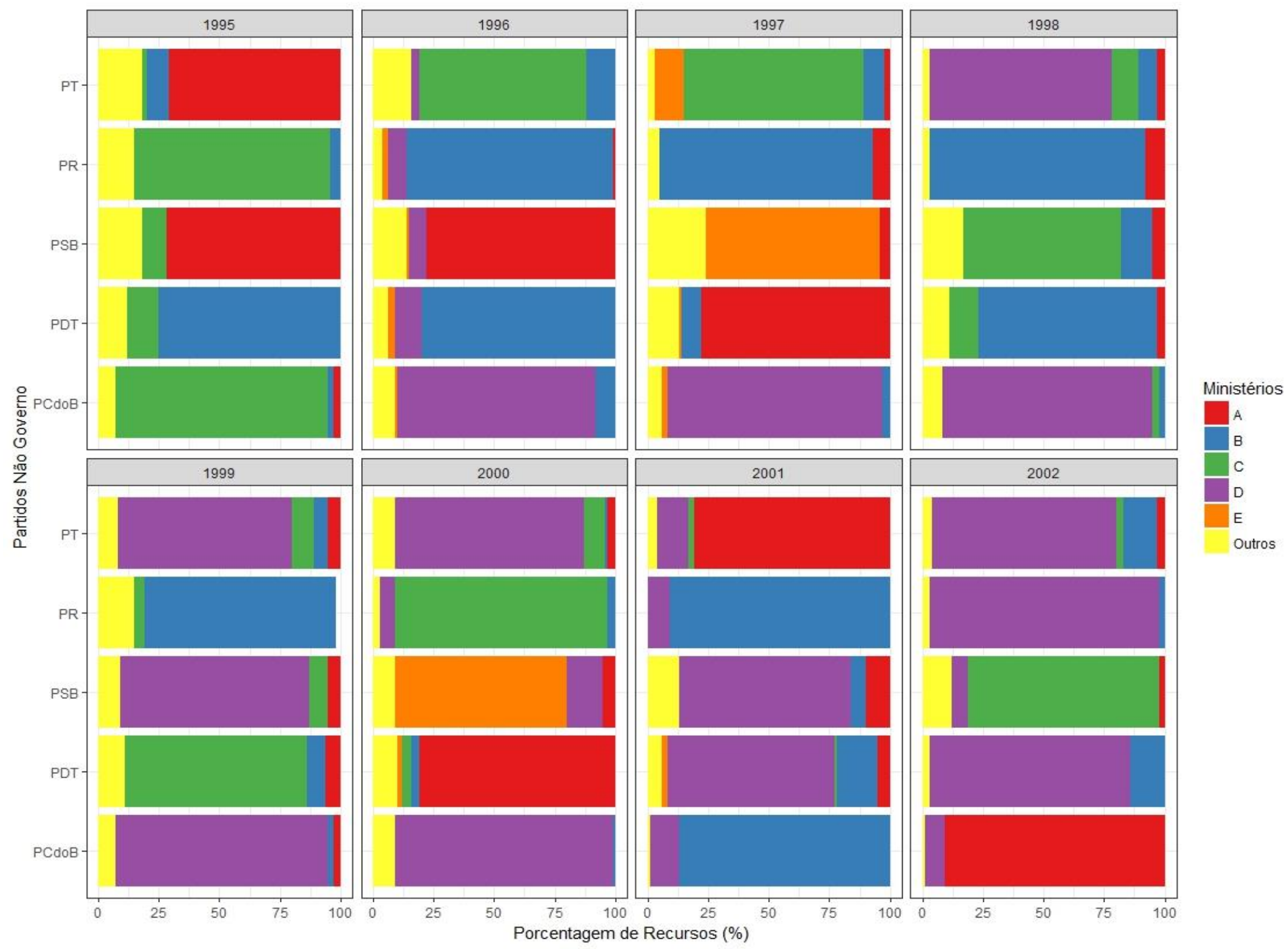

Fonte: Banco de dados do Orçamento da União do Cebrap e Siga Brasi 
Conforme é possível observar no Gráfico 13, os parlamentares de um mesmo partido concentram, juntos, suas emendas em um ministério específico, dentre os cinco ministérios que mais possuem recursos para executá-las. E, indo além, ao contrário do que seria esperado, essa concentração de recursos é estabelecida em ministérios diferentes de acordo com o partido no qual o parlamentar pertence. Explico melhor.

No ano de 1995 sob o governo de FHC, por exemplo, se todos os partidos tivessem destinado a maior parcela de recursos para o Ministério que mais detinha verbas sob a rubrica de investimento naquele ano, a maior parte da área de todas as barras de recursos destinados para os ministérios deveria estar preenchida com a cor vermelha. Nesse sentido, os parlamentares do PT, do PR, do PSB, do PTD e do PCdoB deveriam apresentar maior concentração de seus recursos sob o Ministério indicado como A. Caso esse fosse o padrão observado, o argumento de que o partido político importa para o cálculo os atores políticos perderia força, ao passo o argumento de que há atuação mais individualizada ganharia destaque.

No entanto, esse não é o padrão observado como aponta o Gráfico 13. Retomando o ano usado no exemplo dado acima, é possível observar claramente que parlamentares de partidos diferentes não só concentram suas emendas em ministérios que possuem maior parcela de recursos, como também escolhem ministérios diferentes para alocarem suas emendas. Enquanto o PT e o PSB destinam a maior parcela de seus recursos para o Ministério da posição A, os parlamentares do PR e do PCdoB concentram seus recursos no terceiro ministério que mais detém verbas para executar as emendas, ou seja, no Ministério posicionado em C. Os parlamentares do PDT, por sua vez, concentram recursos no Ministério elencado na posição B.

Realizando uma leitura completa dos dados para todos os demais anos é possível observar o mesmo comportamento. Parlamentares concentram recursos em um ministério específico. E a escolha por esses ministérios, para além de ser estabelecida em termos da parcela que o ministério detém para executar as emendas, varia de acordo com o partido no qual o parlamentar pertence.

O Gráfico 14 apresenta os mesmos dados os cinco maiores partidos que ficaram fora da base do governo durante os anos de 2003 e 2010 
Gráfico 14: Destino das emendas individuais dos parlamentares que não pertencem a base do governo de acordo com os Ministérios que mais detém recursos em Investimentos (2003 -2010)

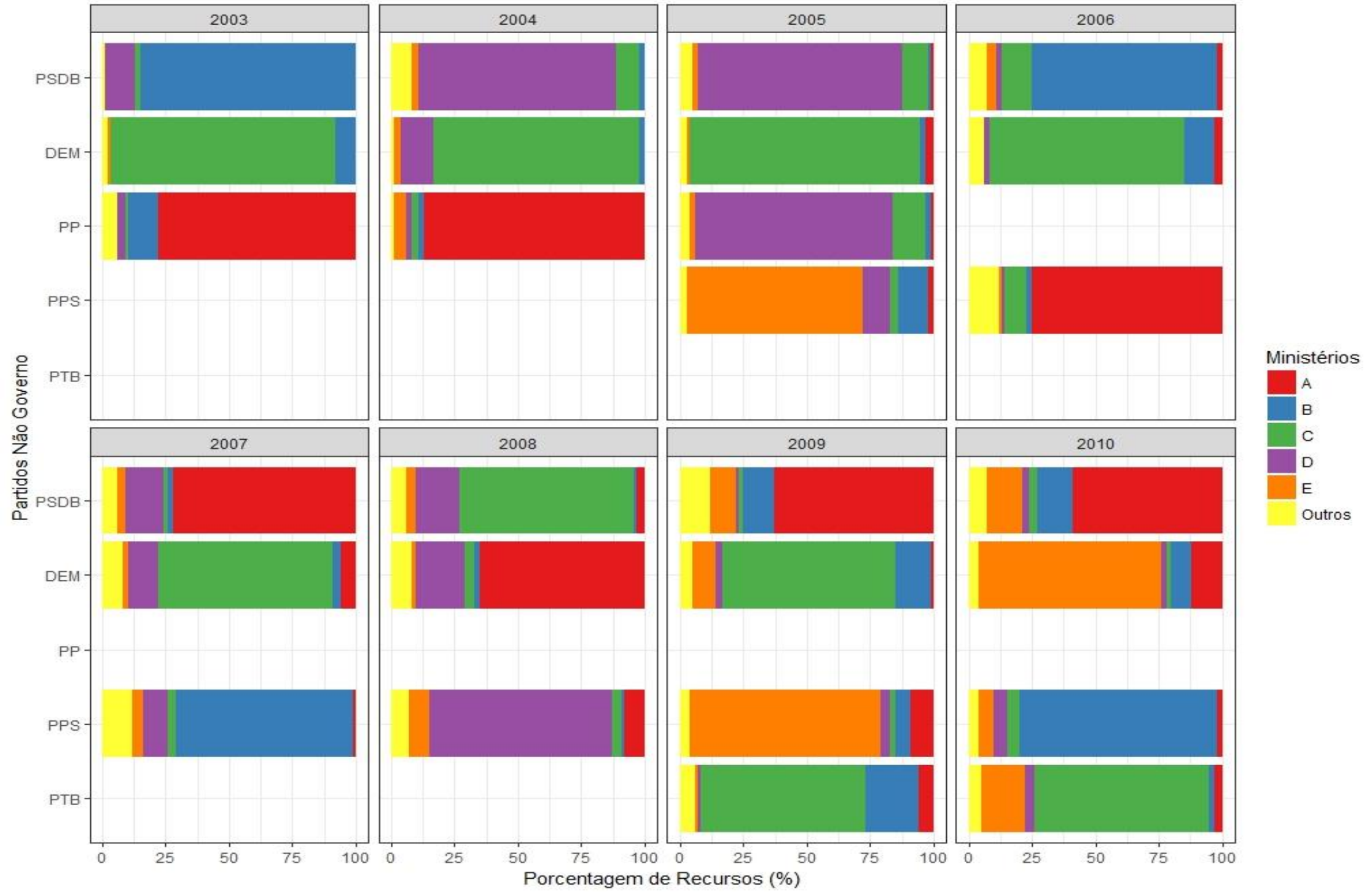

Fonte: Banco de Dados do Orçamento da União do Cebrap e Siga Brasil 
O Gráfico 14 reforça os achados anteriores. No período de 2003 a 2010 os partidos que não pertenciam a base aliada do governo também concentram recursos em um dentre os cinco ministérios que mais possuem verbas disponíveis para executar as emendas. No ano de 2005, por exemplo, o PSDB e o PP destinaram a maior parcela de seus recursos em emendas individuais para o quarto ministério, identificado pela letra $\mathrm{D}$, que recebeu mais recursos para executar emendas. Nesse mesmo ano, o DEM destinou a maior parcela dos seus recursos para o terceiro ministério que mais recebeu recursos sob a rubrica de investimentos, enquanto que o PPS destinou a maioria das suas emendas para o quinto ministério com mais recursos.

Ao longo dos anos, apesar dos partidos alternarem os ministérios para os quais destinam a maior parcela de seus recursos, o mesmo padrão de concentração é mantido. No ano de 2010 enquanto os parlamentares do PSDB destinaram a maior parcela de seus recursos para o ministério que mais recebeu dinheiro em investimento, os parlamentes do DEM destinaram seus recursos para o quinto ministério, identificado pela letra E. Da mesma forma, os parlamentares do PPS escolheram concentrar seus recursos no segundo ministério identificado pela letra $\mathrm{B}$, ao passo que os parlamentares do PTB destinaram a maior parcela de suas emendas para o terceiro ministério, identificado pela letra $\mathrm{C}$, que mais recebeu recursos de investimentos.

O que concluo aqui, portanto, é que até mesmo quando os parlamentares não pertencem à base aliada de governo, estes encontram incentivos para agir de forma estratégica e partidária na alocação de seus recursos. Embora esses parlamentares não possuam o mesmo incentivo dos parlamentares da coalizão, ou seja, o controle sobre uma pasta ministerial, ainda assim esses parlamentares atuam partidariamente, alocando com seus companheiros de partido a maior parcela de suas emendas em um ministério específico.

\subsection{Considerações parciais acerca das evidências apresentadas sobre as emendas individuais aprovadas}

O objetivo das duas seções até aqui apresentadas foi o de mostrar o comportamento dos parlamentares que pertencem a um mesmo partido quando eles se encontram dentro e fora da base aliada do governo. De acordo com a literatura revisada no capítulo anterior a atuação partidária dos parlamentares durante o processo de 
alteração do orçamento no Legislativo não deveria ser observada. A apresentação das emendas deveria ser ditada por considerações individuais.

Os estudos que trataram do assunto concentraram seus esforços para demonstrar a importância destas emendas a garantir o sucesso eleitoral dos parlamentares. Alguns procuram demonstrar que elas seriam vitais (AMES, 2003; PEREIRA; RENNO, 2001, 2007) enquanto outros trazem evidência que sua importância é diminuta (FIRPO; PONCZEK; SANFELICE, 2015; MESQUITA, 2008; MESQUITA et al., 2014). Em comum, neste debate, a ausência dos partidos, desconsiderados como fator explicativo para a atuação dos parlamentares.

No entanto, o que os dados apresentados acima demonstram é que há evidências para se acreditar que os parlamentares não excluem o partido político de seus cálculos eleitorais. Dando um passo atrás e olhando para a fase de elaboração dessas emendas, é possível observar que os parlamentares de um mesmo partido atuam juntos. Seja para apoiar as políticas realizadas pelo seu próprio partido quando este ocupa uma pasta ministerial, seja para juntos apoiarem uma mesma política de um ministério específico quando estão fora da base aliada do governo. Os parlamentares, portanto, atuam partidariamente.

Não desconsidero que o resultado final esperado desse cálculo ou estratégia de atuação dos parlamentares seja ver sua emenda executada. O que argumento é que para atingir esse objetivo, ao contrário do que Mainwaring (1993, 1995), Ames (1995, 2003) e Pereira e Mueller $(2002,2003)$ argumentam, os parlamentares brasileiros não agem individualmente, respondendo apenas aos incentivos do sistema eleitoral de representação proporcional de lista aberta. Muito pelo contrário. Os parlamentares até mesmo nesse momento de atuação individual no orçamento, a organização dos trabalhos na arena Legislativa força a que ajam partidariamente, isto é, recorrer ao partido é a melhor estratégia.

Adiante, na próxima seção, aprofundo esta perspectiva, analisando com mais detalhes qual a estratégia adotada pelos partidos que estão na coalizão e que ocupam pastas ministeriais na execução das emendas individuais orçamentárias.

\section{Emendas individuais executadas}

Nessa segunda etapa, o universo de análise a ser trabalhado, como apresentado no capítulo anterior, contará com todas as emendas individuais executadas. Se na etapa anterior, em que as emendas individuais aprovadas foram alvo das análises, os 
parlamentares de um mesmo partido foram tomados como ponto de partida, agora o foco irá recair sobre os partidos a frente das pastas ministeriais.

Isso acontece, porque uma vez que os parlamentares já escolheram em quais ministérios alocar suas emendas, a decisão sobre a execução $\mathrm{r}$ desses recursos, como visto no Capítulo1, recaí sobre o Executivo e, principalmente, sobre os ministros que controlam pastas ministeriais. Assim, de modo a perseguir as outras duas hipóteses levantadas nesse trabalho, as análises serão realizadas tendo em vista os parlamentares de quais partidos mais são beneficiados com recursos das emendas executadas por ministérios.

Dito isso, vale aqui relembrar quais serão a serem exploradas nessa seção:

$H_{3}$ : Parlamentares da coalizão têm mais recursos executados do que os que não pertencem ao governo;

$H_{4}$ : Parlamentares com a mesma filiação partidária que a do ministro têm mais recursos executados do que os parlamentares pertencentes a outros partidos da coalizão;

Adiante, apresentarei rapidamente a execução das emendas individuais de acordo com os parlamentares que pertencem e que não pertencem ao governo para a série temporal aqui explorada. Realizada essa exposição, o cerne das análises será a apresentação dos dados da execução das emendas individuais orçamentárias de acordo com o partido que controla a pasta ministerial e os parlamentares que possuem emendas alocadas no ministério.

\subsection{Ser governo e não ser governo faz diferença}

De modo a atingir a finalidade dessa seção, que é a de mostrar como os parlamentares da coalizão têm taxas superiores de execução das suas emendas, duas principais variáveis serão usadas:

1. Porcentagem de recursos executados: média da porcentagem de recursos executados por ano.

2. Situação: Variável dummy que identifica se o parlamentar que recebe o recurso é da coalizão de governo ou está situado fora da base aliada do governo. 
Adiante o Gráfico 15 apresenta a taxa média de recursos executados em emendas que os parlamentares que pertencem à coalizão de governo e os parlamentares que não pertencem ao governo receberam ao longo do ano.

\section{Gráfico 15: Recursos emendas executadas recebidas pelos parlamentares da coalizão e pelos parlamentares "Não Governo" (1995-2010)}

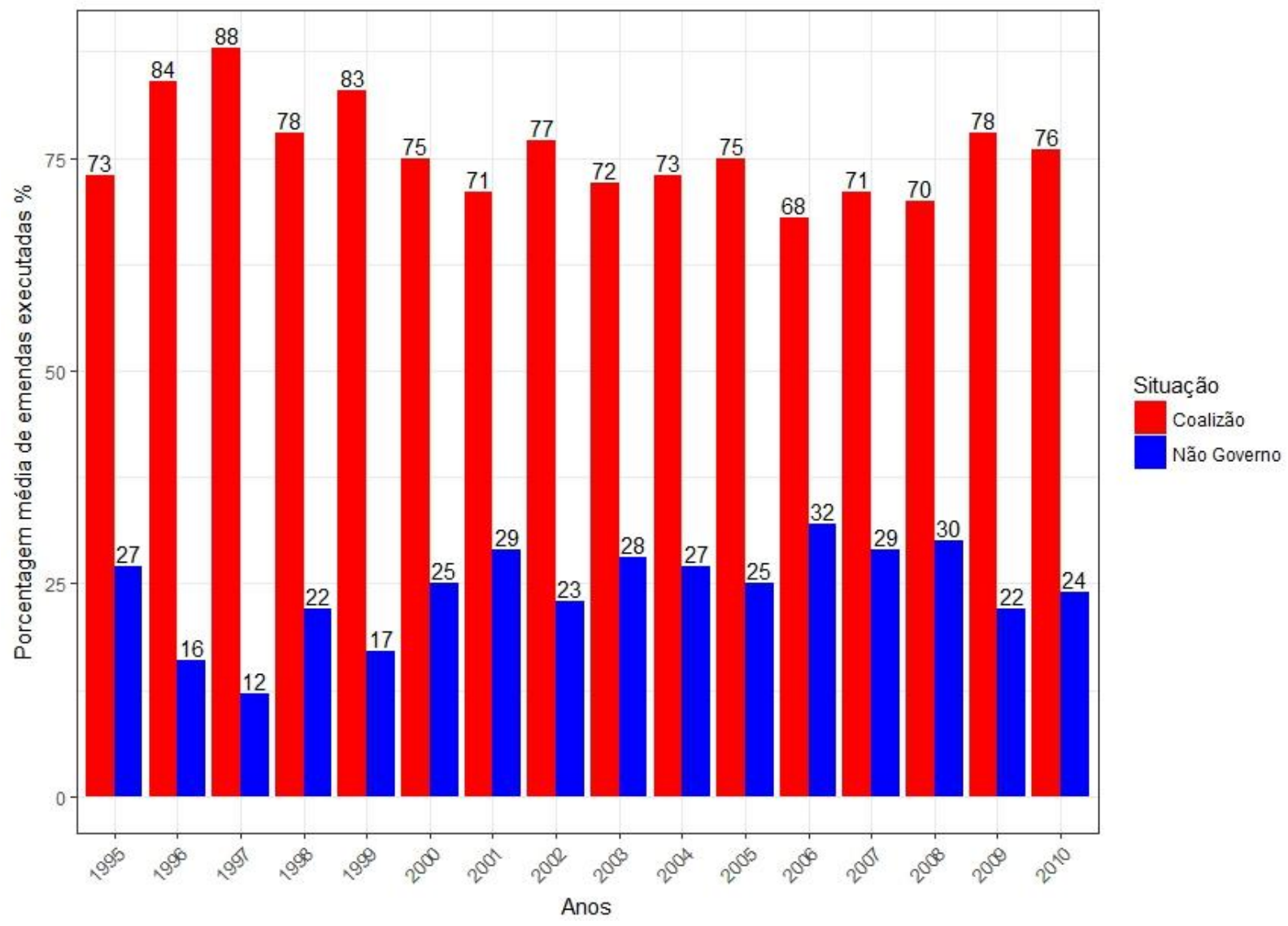

Fonte: Banco de dados do Orçamento da União do Cebrap e Siga Brasil

Como é possível observar, os parlamentares que pertencem à coalizão de governo são os mais beneficiados com emendas executadas do que os situados fora da base aliada. Em todos os anos, com exceção ao ano de 2006, os parlamentares da coalizão são os que recebem mais de $70 \%$ dos recursos com as emendas executadas, enquanto que os parlamentares que não pertencem ao governo recebem, em média, 24\%.

Esses dados apresentados servem para comprovar, mais uma vez, que realmente os parlamentares que estão situados na base do governo são beneficiados com os recursos das emendas individuais executadas. Para as finalidades desse trabalho esses dados não são decisivos. Contudo, se de um lado a afirmativa de que os parlamentares da coalizão 
recebem mais recursos não mostra nenhuma evidência de que existe coordenação partidária no orçamento brasileiro, no outro lado ela também não nega sua existência.

O que argumento é que é preciso olhar para esses dados de outra forma. Estabelecido que é de responsabilidade de cada Ministério, representado pela figura do Ministro, decidir como e o que será executado, buscarei olhar adiante, para como cada ministro distribui a execução das emendas, detalhando os partidos que controlam as pastas ministeriais e o partido dos parlamentares que são beneficiados com esses recursos.

\subsection{Mais do que ser governo: o partido importa}

Anteriormente, olhei para como a distribuição dos recursos das emendas executadas é estabelecida entre os parlamentares que pertencem e os que não pertencem a base aliada do governo. O objetivo desta seção é adicionar mais um elemento nessa análise. Na busca por encontrar evidências de que há coordenação partidária também na fase da execução das emendas, o que pretendo mostrar aqui é que cada ministro procura beneficiar e atender aos seus próprios parlamentares na execução das emendas. Assim, as análises que serão realizadas aqui terão como foco os ministérios controlados por um mesmo partido e a execução das emendas.

No Gráfico 16 adiante, apresento, novamente, os onze partidos que controlaram alguma pasta ministerial ao longo do período aqui analisado e como cada um desses partidos decidiu distribuir os recursos das emendas individuais executadas entre os parlamentares que pertenciam a base do governo e os que não pertenciam. 
Gráfico 16: Média dos recursos executados em emendas individuais de acordo com o controle da pasta ministerial e os parlamentares (1995-2010)

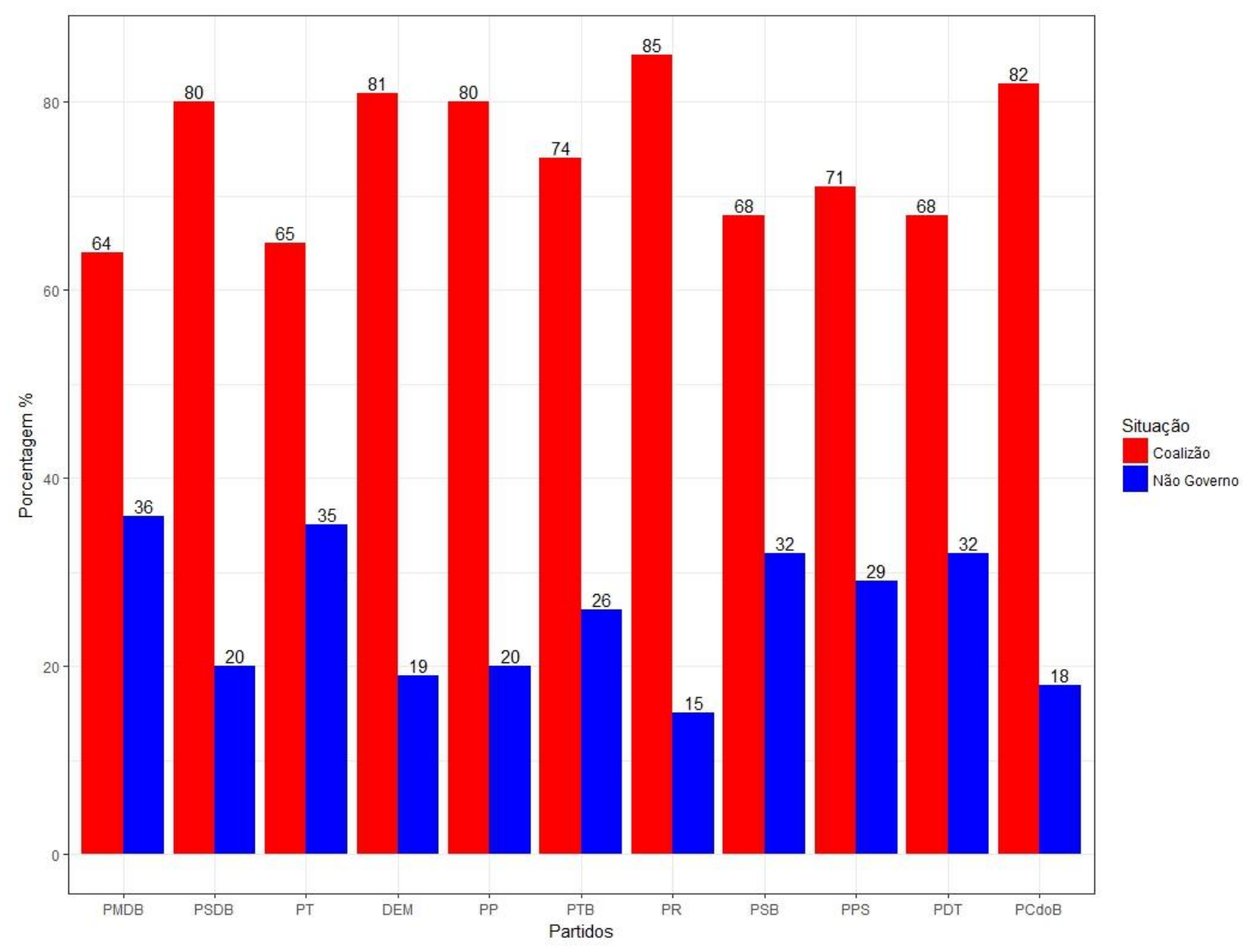

Fonte: Banco de dados do Orçamento da União do Cebrap e Siga Brasil

Todos os ministros, sem exceção, quando estão à frente de pastas ministeriais procuram destinar a maior parte dos recursos em emendas executadas para os parlamentares que pertencem à coalizão de governo. É assim, por exemplo, os ministros ligados ao PSDB, ao DEM, ao PP, ao PR, ao PPS e ao PCdoB destinam mais de 70\% dos recursos em emendas executadas para os parlamentares da coalizão. Ficam atrás somente os ministros do PMDB, do PT, do PSB e do PDT que destinam, em média, 66\% dos recursos também para os parlamentares aliados a base do governo. Os parlamentares que se encontram fora da base do governo também possuem emendas executadas, mas como os dados aqui mostram, eles recebem, em média, somente $25 \%$ dos recursos que os ministérios utilizam para executar as emendas.

Esses dados não só corroboram ainda mais as evidências favoráveis à primeira hipótese aqui delineada, como também nos permitem dar um passo adiante: será que, 
dentre os parlamentares que estão na coalizão, os ministros resolvem premiar mais os parlamentares pertencentes aos seus respectivos partidos? De modo a responder a essa questão, apresento abaixo o Gráfico 17.

Gráfico 17: Média dos recursos executados em emendas individuais de acordo com os parlamentares que pertencem ao mesmo partido do ministro (1995-2010)

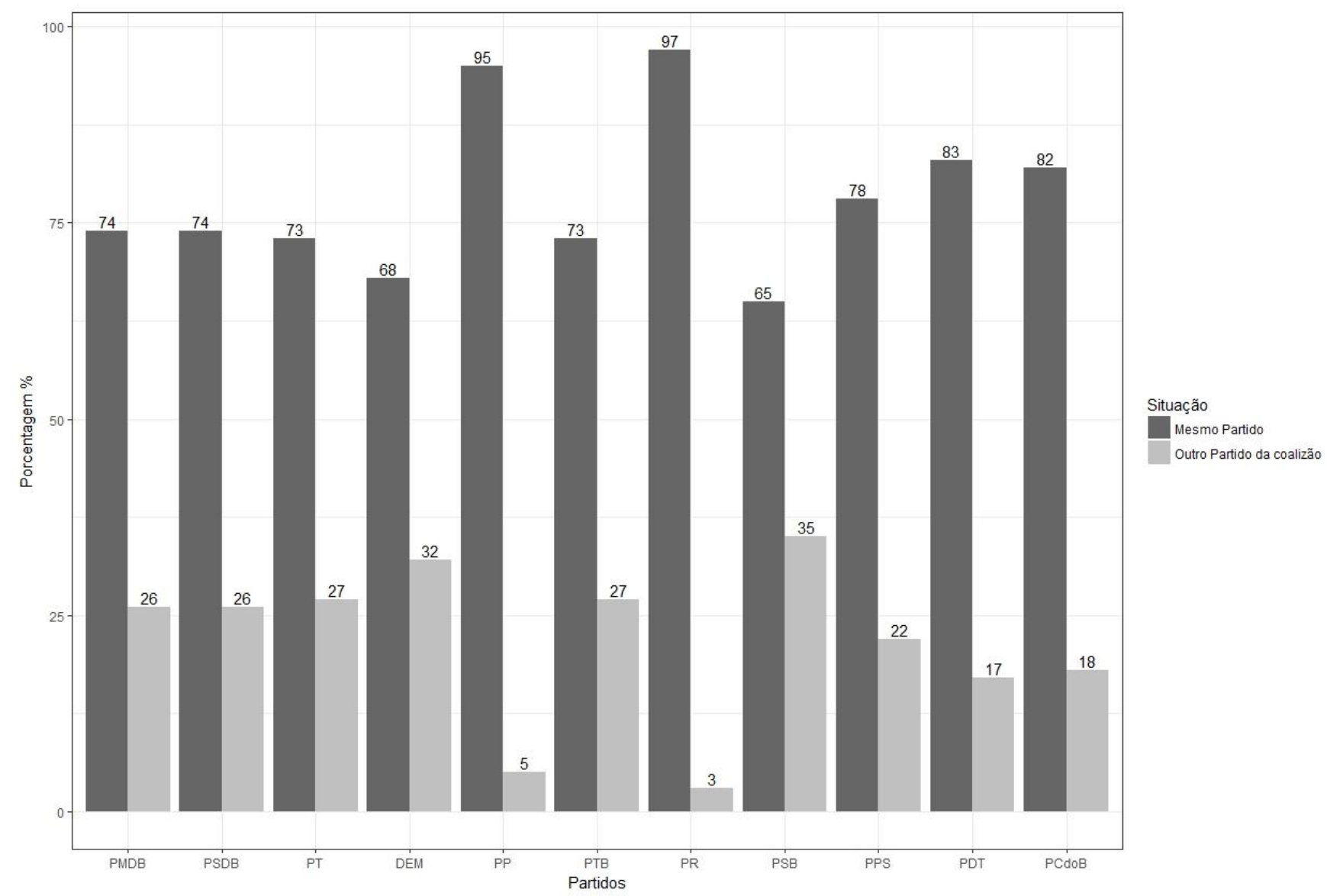

Fonte: Banco de dados do Orçamento da União do Cebrap e Siga Brasil

Como é possível notar, os partidos, quando a frente de pastas ministeriais, priorizam os parlamentares dos seus respectivos partidos no destino das emendas executadas. Assim é que, por exemplo, os ministros do PR e do PP destinam, em média, mais de $90 \%$ dos recursos executados com as emendas da coalizão para os seus respectivos parlamentares. Os demais partidos também seguem esse padrão quando a frente de ministérios. PDT e PCdoB destinam, em média, mais de $80 \%$ dos recursos para seus parlamentares, enquanto que os ministros do PMDB, PSDB, PT, PTB e PPS destinam também, em média, mais de $70 \%$. 
Os demais partidos da coalizão também têm emendas executadas nas pastas ministeriais que não são controladas pelo seu partido. Contudo, a parcela de recursos que eles recebem é bem menor. Em média, os parlamentares pertencentes aos demais partidos parceiros da coalizão de governo recebem $22 \%$ dos recursos alocados para a coalizão como um todo.

\subsection{Considerações parciais acerca das evidências sobre a alocação dos recursos das emendas individuais executadas}

Uma afirmação é certa: mais importante do que ser parte integrante da coalizão para ter recursos executados, é pertencer ao mesmo partido que ocupa uma pasta ministerial. Os dados que aqui foram apresentados comprovam que, de acordo com a segunda hipótese desenhada, parlamentares com a mesma filiação partidária que a do ministro têm mais recursos executados do que os demais parlamentares pertencentes a outros partidos da coalizão e do que os parlamentares que estão situados fora do governo.

Retomando e o argumento exposto por Figueiredo e Limongi (2008), a execução das emendas individuais realmente faz parte de um acordo mais amplo entre os partidos que compõe a coalizão de governo. E é preciso aqui pontuar: se quando o governo executa uma emenda de um parlamentar aliados a sua base de governo, ele está executando também sua agenda de políticas, o mesmo argumento pode ser utilizado para a execução das emendas no interior de um mesmo partido.

Quando um ministro a frente de uma pasta ministerial distribui mais emendas executadas para os parlamentares filiados a seu partido político, ele não está nada a mais, nada a menos do que selando um acordo político firmado anteriormente entre os membros de um mesmo partido. Parlamentastes quando entram em um partido político aceitam ter suas preferências moldadas para que um objetivo único, uma política única possa ser realizada. A execução dessas emendas não pode ser tratada única e exclusivamente como a 'compra' de apoio. Trata-se, sobretudo, de colocar em prática as políticas acordadas pelos membros de um mesmo partido. Ao ter uma emenda executada, mais do que angariar recursos para as suas clientelas eleitorais, parlamentares estão executando a política elaborada e pensada no interior de seus respectivos partidos políticos.

Assim, o que concluo a partir dos dados aqui apresentados é que os partidos se fazem presente também na execução das emendas orçamentárias. E essa coordenação não ocorre simplesmente e somente entre os partidos que compõem a base de governo. Essa 
coordenação, antes de tudo, é dada no interior de cada partido. Parlamentares pertencentes a um mesmo partido recebem mais emendas executadas das pastas ministeriais nas quais seus partidos controlam. 


\section{CONCLUSÃO}

As emendas individuais orçamentárias sempre foram vistas como um elemento essencial para o parlamentar conseguir drenar recursos para seus redutos eleitorais e, por isto mesmo, como uma ferramenta útil para o Executivo comprar o apoio dos parlamentares para a aprovação de sua agenda de políticas. Nesse cenário, os parlamentares seriam vistos como atores autônomos e, ao contrário dos demais trabalhos no interior da arena legislativa, os partidos não seriam necessários para coordenar suas ações. Na alteração da Lei Orçamentária Anual (LOA), os parlamentares estariam livres para atuar sem a canga dos partidos. Atuariam, portanto, seguindo sua própria vontade.

$\mathrm{Na}$ contramão dessa visão comumente empregada, este trabalho teve como objetivo principal mostrar evidências fortes o suficiente para se acreditar que no momento da alteração da LOA os parlamentares não atuam tão livremente assim. Até mesmo nessa esfera de atuação os partidos políticos aparecem como agentes responsáveis por coordenar a ação dos parlamentares. Assim como nas demais tarefas e trabalhos legislativos desempenhados pelos parlamentares no interior do Legislativo, ao participarem do processo orçamentário, os atores políticos também reconheceriam que atuar por intermédio dos seus partidos pode lhes garantir maiores benefícios.

Como foi possível de observar, parlamentares que pertencem à base aliada do governo destinam a maior parcela de seus recursos em emendas individuais orçamentárias para os ministérios controlados pelos seus respectivos partidos. Isso evidenciaria não só um apoio às políticas produzidas pelos partidos políticos no interior da coalizão de governo, como também demonstraria que os parlamentares, no interior da arena orçamentária, também reconhecem que sua melhor estratégia de atuação deve ser por meio dos partidos políticos.

Da mesma forma, quando os parlamentares de um mesmo partido estão situados fora da base aliada do governo, apoiar as políticas implementadas por um ministério, parece ser a melhor estratégia. Parlamentares de um mesmo partido, para além de alocarem suas emendas nos Ministérios com mais recursos para executá-las, fazem isso partidariamente. Os partidos situados fora do governo não escolhem todos, ao mesmo tempo, o ministério com mais recursos. Eles escolhem ministérios diferentes. Os ministérios escolhidos variam de um partido para o outro. Assim, os dados apresentados anteriormente parecem não deixar dúvidas: parlamentares, ainda que interessados em conquistar seus redutos eleitorais, reconheceriam que atuar em conjunto com o seu partido 
é a melhor estratégia, ou a melhor chance que eles possuem, de ver suas emendas executadas e, assim, angariar recursos para seus redutos eleitorais.

Do outro lado da moeda, ou seja, olhando para a execução das emendas individuais e para o poder de decisão que os Ministros detêm sobre elas, também é possível identificar a presença de coordenação partidária. A literatura já apontava para o fato de os membros da coalizão serem mais beneficiados com a execução desses recursos do que os membros que estão situados fora do governo. Indo além dessa constatação, o que o presente trabalho procurou mostrar é que para a execução dessas emendas mais do que ser governo, pertencer ao mesmo partido que o do Ministro também importa.

O que os dados que aqui foram apresentados revelam é que os partidos quando a frente de pastas ministeriais distribuírem a maior parte das emendas executadas não só entre os membros da coalizão, mas entre os membros do seu próprio partido. Dito de forma mais clara e direta: os Ministros executam mais as emendas que são provenientes dos parlamentares que pertencem ao mesmo partido que o seu.

Por sua vez, é preciso pontuar que executar as emendas dos membros do seu partido não significa aqui que há compra de apoio desses parlamentares. Muito pelo contrário. Como afirmei anteriormente, quando os ministros executam as emendas dos membros do seu próprio partido mais do que colocar em prática a agenda de políticas formulada pelo seu próprio partido, o Ministro também está ratificando os acordos firmados entre os parlamentares e suas distintas preferências no interior de um mesmo partido.

Enfim, ainda que o momento de atuação dos parlamentares na alteração da peça orçamentária seja um dos momentos em que o parlamentar mais tem a oportunidade para atuar sem a presença dos partidos políticos, o que este trabalho procurou mostrar é que os parlamentares reconhecem que, até mesmo nesse momento, atuar por intermédio dos seus partidos políticos, mantendo acordos políticos firmados previamente, é a melhor estratégia de atuação que ele detém para maximizar seus interesses. 


\section{BIBLIOGRAFIA}

ALDRICH, J. H. Why Parties?: The Origin and Transformation of Political Parties in America. [s.1.] University of Chicago Press, 1995.

AMES, B. Electoral Strategy under Open-List Proportional Representation. American Journal of Political Science, v. 39, n. 2, p. 406-433, 1 maio 1995.

AMES, B. Os entraves da democracia no Brasil. [s.1.] FGV Editora, 2003.

AMORIM NETO, O.; SANTOS, F. O segredo ineficiente revisto: o que propõem e o que aprovam os deputados brasileiros. Dados, v. 46, n. 4, p. 661-698, 2003.

ANDRÉA JUNQUEIRA MACHADO. Coordenação Interpartidária no legislativo brasileiro: superando os desafios institucionais. . In: V SEMINÁRIO DISCENTE DA PÓS- GRADUAÇÃO EM CIÊNCIA POLÍTICA DA UNIVERSIDADE DE SÃO PAULO. São paulo, Brasil: 2015

ARANTES, R.; COUTO, C. Uma Constituição Incomum. In: CHIARAMONTE, J. C. (Ed.). . A Constituição de 1988: passado e futuro. [s.l.] Editora HUCITEC, 2009.

BOWLER, S. Parties in Legislatures: Two Competing Explanations. In: DALTON, R. J.; WATtenberG, M. P. (Eds.). . Parties Without Partisans: Political Change in Advanced Industrial Democracies. [s.1.] The Oxford Handbooks, 2002. p. 157-179.

BRASIL. 1 de 1969. Emenda Constitucional Na 1 de 1969. 1969.

BRASIL. Resolução do Congresso Nacional Nº 1 de 1991. 1991.

BRASIL. 1 de 1993. Resolução no 1 de 1993. 1993.

BRASIL. Relatório Final da Comissão Parlamentar Mista de Inquérito do OrçamentoSenado Federal, , 1994.

BRASIL. Resolução do Congresso Nacional Nº 2 de 1995. 1995.

BRASIL. Resolução do Congresso Nacional Nº 1 de 2001. 2001.

BRASIL. Relatório Final da Comissão Parlamentar Mista de Inquérito do Orçamento “CPMI das Ambulâncias”Senado Federal, 2006.

BRASIL. 1 de 2006. Resolução do Congresso Nacional No 1 de 2006. 2006.

CAIN, B.; FEREJOHN, J.; FIORINA, M. The Personal Vote: Constituency Service and Electoral Independence. [s.1.] Harvard University Press, 1990.

CHEIBUB, J. A. Presidentialism, Parliamentarism, and Democracy. [s.l.] Cambridge University Press, 2007.

COX, G. W.; MCCUBBINS, M. D. Legislative Leviathan: Party Government in the House. Berkeley: University of California Press, 1993. 
DANIELA GIANNETTI, M. L. Party cohesion, party factions and legislative party discipline in Italy. 2005.

DINIZ, S. Interações entre os poderes executivo e legislativo no processo decisório: avaliando sucesso e fracasso presidencial. Dados, v. 48, n. 2, p. 333-369, jun. 2005.

DOWNS, A. Teoria Econômica da Democracia, Uma. [s.1.] EDUSP, 1999.

FIGUEIREDO, A. Governments Coalitions in Brazilian Democracies. Brazilian Political Science Review, p. 182-216, 2007.

FIGUEIREDO, A.; LIMONGI, F. Executivo E Legislativo Na Nova Ordem Constitucional. [s.1.] Editora FGV, 1999.

FIGUEIREDO, A.; LIMONGI, F. Incentivos Eleitorais, Partidos e Política Orçamentária. Dados, v. 45, n. 2, p. 303-344, jan. 2002.

FIGUEIREDO, A.; LIMONGI, F. Processo orçamentário e comportamento Legislativo: emendas individuais, apoio ao Executivo e programas de governo. Dados, v. 48, n. 4, p. 737-776, 2005.

FIGUEIREDO, A.; LIMONGI, F. Política Orçamentária no Presidencialismo de Coalizão. [s.1.] Editora FGV, 2008.

FIGUEIREDO, A.; LIMONGI, F. Poder de Agenda e Políticas Substantivas. In: MAGNA, I.; RENNÓ, LÚCIO (Eds.). . Legislativo Brasileiro em Perspectiva Comparada. [s.1.] UFMG, 2009. p. 77-104.

FIRPO, S.; PONCZEK, V.; SANFELICE, V. The relationship between federal budget amendments and local electoral power. Journal of Development Economics, v. 116, p. 186-198, set. 2015.

FREITAS, A. M. DE. O Presidencialismo da coalizão, Publicações, Fundação Konrad Adenauer no Brasil. [s.l: s.n.].

GIACOMONI, J. Orçamento público. [s.1.] Atlas, 2012.

HAZAN, R. Y. H. S. Does Cohesion Equal Disicipline? Towards a Conceptual Delineation. The Journal of Legislative Studies, v. 9, n. 4, p. 1-11, 21 dez. 2003.

KREHBIEL, K. Where's the Party? British Journal of Political Science, v. 23, n. 2, p. 235-266, 1 abr. 1993.

LAMOUNIER, B. Estrutura Institucional e governabilidade na década de 1990. In: REIS VELLOSO, J. P. DO (Ed.). . O Brasil e as Reformas Políticas. [s.1.] José Olympio, 1992.

LAVER, M.; SCHOFIELD, N. Multiparty Government: The Politics of Coalition in Europe. New edition edition ed. Ann Arbor: University of Michigan Press, 1998.

LINZ, J. J. Presidencialismo ou Parlamentarismo: Faz alguma diferença? In: LAMOUNIER, B. (Ed.). . A opção parlamentarista. [s.1.] IDESP/Sumaré, 1991. 
MAINWARING, S. Presidentialism, Multipartism, and Democracy The Difficult Combination. Comparative Political Studies, v. 26, n. 2, p. 198-228, 1993.

MAINWARING, S. Building Democratic Institutions: Party Systems in Latin America. [s.1.] Stanford University Press, 1995.

MARTINS, G. V. Processo Legislativo Orçamentário Federal: Evolução das Resoluções Orçamentárias pós Constituição de 1988. Brasília: Centro de Formação, Treinamento e Aperfeiçoamento da Câmara dos Deputados/ Cefor, 2012.

MAYHEW, D. R. Congress: The Electoral Connection. [s.l.] Yale University Press, 1974.

MEDEIROS, D. B. Organizando maiorias, agregando preferências: a Assembleia Nacional Constituinte de 1987-88. Dissertação de Mestrado-São Paulo: Faculdade de Filosofia, Letras e Ciências Humanas, Universidade de São Paulo, 2013.

MESQUITA, L. Emendas ao orçamento e conexão eleitoral na Câmara dos Deputados. [s.1.] Universidade de São Paulo, 2008.

MESQUITA, L. et al. Emendas Individuais e Concentração de Votos: uma análise exploratória. . In: IX ENCONTRO DA ABCP. Brasília, Brasil: 2014

MÜLLER, W. C.; STRØM, K. (EDS.). Policy, Office, or Votes?: How Political Parties in Western Europe Make Hard Decisions. Cambridge England; New York: Cambridge University Press, 1999.

OLSON, M. THE LOGIC OF COLLECTIVE ACTION. [s.1.] Harvard University Press, 1965.

OWENS, J. Explaining party cohesion and discipline in democratic legislatures: purposiveness and contexts. Journal of Legislative Studies, v. 9, n. 4, p. 12-40, 1 jan. 2003.

PEREIRA, C.; MUELLER, B. Comportamento Estratégico em Presidencialismode Coalizão: As Relações entre Executivo e Legislativo na Elaboração do Orçamento Brasileiro. Dados, v. 45, n. 2, p. 265-301, 2002.

PEREIRA, C.; MUELLER, B. Partidos fracos na arena eleitoral e partidos fortes na arena legislativa: a conexão eleitoral no Brasil. Dados, v. 46, n. 4, p. 735-771, 2003.

PEREIRA, C.; RENNO, L. O que é que o reeleito tem? Dinâmicas político-institucionais locais e nacionais nas eleições de 1998 para a Câmara dos Deputados. Dados - Revista de Ciências Sociais, v. 44, n. 2, p. 133-172, 2001.

PEREIRA, C.; RENNO, L. O que é que o reeleito tem? O retorno: o esboço de uma teoria da reeleição no Brasil. Revista de Economia Política, v. 27, n. 4, p. 664-683, dez. 2007.

PRAÇA, S. A evolução de instituições orçamentárias no Brasil, 1987-2008. [s.l.] Universidade de São Paulo, 2010. 
SANCHES, O. O processo orçamentário fedral: problemas, causas e indicativos de soluções. Revista de administração pública, v. 29, 1995.

SANTOS, F. Patronagem e Poder de Agenda na Política Brasileira. Dados, v. 40, n. 3, 1997.

SANTOS, F. Partidos e Comissões no Presidencialismo de Coalizão. Dados, v. 45, n. 2, p. 237-264, 2002.

SCHATTSCHNEIDER, E. E. Party government... [s.1.] Transaction Publishers, 1942.

SHEPSLE, K. A.; WEINGAST, B. R. The Institutional Foundations of Committee Power. The American Political Science Review, v. 81, n. 1, p. 85-104, 1987.

SHEPSLE, K. A.; WEINGAST, B. R. Positive Theories of Congressional Institutions. Legislative Studies Quarterly, v. 19, n. 2, p. 149-179, 1994.

SILVA, M. B. A Conexão Ministerial: governo de coalizão e viés partidário na alocação de emendas parlamentares ao orçamento (2004-2010). . In: $36^{\circ}$ ENCONTRO ANUAL DA ANPOCS. Águas de Lindóia: 2012

THIES, M. F. On the Primacy of Party in Government. Parties Without Partisans: Political Change in Advanced Industrial Democracies, 2002.

VASSELAI, F.; MIGNOZZETTI, U. G. O Efeito das Emendas ao Orçamento no Comportamento Parlamentar e a Dimensão Temporal: Velhas Teses, Novos Testes. Dados, v. 57, n. 3, p. 817-853, set. 2014.

WEINGAST, B. R.; SHEPSLE, K. A.; JOHNSEN, C. The Political Economy of Benefits and Costs: A Neoclassical Approach to Distributive Politics. Journal of Political Economy, v. 89, n. 4, p. 642-664, 1981. 
ANEXOS

Anexo 1: Coalizões governamentais no Brasil (1988-2014)

\begin{tabular}{|c|c|c|c|c|c|c|}
\hline \multirow{2}{*}{$\begin{array}{l}\text { Coalizão/ } \\
\text { Presidente }\end{array}$} & \multicolumn{2}{|c|}{ Data da Coalizão } & \multirow{2}{*}{ Partidos da Coalizão } & \multirow[t]{2}{*}{ Evento de início da nova coalizão } & \multicolumn{2}{|c|}{$\begin{array}{l}\text { \% de Cadeiras do Partido do Presidente na } \\
\text { CD }\end{array}$} \\
\hline & Início & Fim & & & Início & Fim \\
\hline Sarney 2 & 06 -out-88 & $14-m a r-90$ & PMDB - PFL & Promulgação da Constituição & $40,8 \%$ & $31,9 \%$ \\
\hline Collor 1 & 15 -mar-90 & 12-out-90 & PRN - PFL & Eleição presidencial & $5,1 \%$ & $6,1 \%$ \\
\hline Collor 2 & 13 -out-90 & 31-jan-91 & PRN - PFL - PDS & PDS entra & $6,0 \%$ & $5,8 \%$ \\
\hline Collor 3 & 01-fev-91 & $14-a b r-92$ & PRN - PFL - PDS & Eleição Legislativa & $8,2 \%$ & $6,2 \%$ \\
\hline Collor 4 & $15-a b r-92$ & 30 -set-92 & PRN - PFL - PDS - PTB - PL & PTB e PL entram & $6,2 \%$ & $5,8 \%$ \\
\hline Itamar 1 & 01-out-92 & 30-ago-93 & PFL - PTB - PMDB - PSDB - PSB & Impeachment de Collor & $0,0 \%$ & $0,0 \%$ \\
\hline Itamar 2 & 31-ago-93 & 24-jan-94 & PFL - PTB - PMDB - PSDB - PP & PSB sai e PP entra & $0,0 \%$ & $0,0 \%$ \\
\hline Itamar 3 & 25-jan-94 & 31-dez-94 & PFL - PMDB - PSDB - PP & PTB sai & $0,0 \%$ & $0,0 \%$ \\
\hline FHC I 1 & 01-jan-95 & $25-a b r-96$ & PSDB - PFL - PMDB - PTB & Eleições presidencial e legislativa & $12,1 \%$ & $16,6 \%$ \\
\hline FHCI 2 & $26-a b r-96$ & 31-dez-98 & PSDB - PFL - PMDB - PTB - PPB & PPB entra & $16,6 \%$ & $18,3 \%$ \\
\hline FHC II 1 & 01-jan-99 & 05-mar-02 & PSDB - PFL - PMDB - PPB & Eleições presidencial e legislativa & $19,3 \%$ & $18,3 \%$ \\
\hline FHC II 2 & 06-mar-02 & 31-dez-02 & PSDB - PMDB - PPB & PFL sai & $18,3 \%$ & $18,3 \%$ \\
\hline Lula I 1 & 01-jan-03 & 22-jan-04 & PT - PL - PCdoB - PSB - PTB - PDT - PPS - PV & Eleições presidencial e legislativa & $17,7 \%$ & $17,5 \%$ \\
\hline Lula I 2 & 23-jan-04 & 31-jan-05 & PT - PL - PCdoB - PSB - PTB - PPS - PV - PMDB & PDT sai e PMDB entra & $17,5 \%$ & $17,5 \%$ \\
\hline Lula I 3 & 01-fev-05 & 19-mai-05 & PT - PL - PCdoB - PSB - PTB - PV - PMDB & PPS sai & $17,5 \%$ & $17,7 \%$ \\
\hline Lula I 4 & 20-mai-05 & 22-jul-05 & PT - PL - PCdoB - PSB - PTB - PMDB & PV sai & $17,7 \%$ & $17,5 \%$ \\
\hline Lula I 5 & 23-jul-05 & 31-dez-06 & PT - PL - PCdoB - PSB - PTB - PMDB - PP & PP entra & $17,5 \%$ & $15,8 \%$ \\
\hline Lula II 1 & 01-jan-07 & $01-a b r-07$ & PT - PR - PCdoB - PSB - PTB - PMDB - PP - PRB & Eleições presidencial e legislativa & $16,2 \%$ & $16,0 \%$ \\
\hline Lula II 2 & 02-abr-07 & 27-set-09 & PT - PR - PCdoB - PSB - PTB - PMDB - PP - PDT - PRB & PDT entra & $16,0 \%$ & $15,4 \%$ \\
\hline Lula II 3 & 28-set-09 & 31-dez-10 & PT - PR - PCdoB - PSB - PMDB - PP - PDT - PRB & PTB sai & $15,4 \%$ & $15,0 \%$ \\
\hline Dilma I 1 & 01-jan-11 & 01-mar-12 & PT - PR - PCdoB - PSB - PMDB - PDT - PP & Eleições presidencial e legislativa & $17,2 \%$ & $17,0 \%$ \\
\hline Dilma I 2 & 02-mar-12 & 02-out-13 & PT - PR - PCdoB - PSB - PMDB - PDT - PP- PRB & PRB entra & $17,0 \%$ & $17,2 \%$ \\
\hline Dilma I 3 & 03-out-13 & 31-dez-14 & PT - PR - PCdoB - PMDB - PDT - PP- PRB & PSB sai & $17,2 \%$ & $17,2 \%$ \\
\hline
\end{tabular}

Fonte: Banco de Dados do Legislativo do Cebrap 
Anexo 2: Ministérios que mais recebem recursos para executar emendas

\begin{tabular}{|c|c|c|c|}
\hline Ministérios & $\begin{array}{c}\text { Porcentagem de } \\
\text { recursos para executar } \\
\text { as emendas }\end{array}$ & Ministérios & $\begin{array}{l}\text { Porcentagem de } \\
\text { recursos para executar } \\
\text { as emendas }\end{array}$ \\
\hline \multicolumn{2}{|l|}{1995} & \multicolumn{2}{|c|}{1999} \\
\hline M. Meio Ambiente & $48 \%$ & M. Esporte e Turismo & $68 \%$ \\
\hline M. dos Transportes & $42 \%$ & M. Transportes & $55 \%$ \\
\hline M. dos Esportes & $29 \%$ & M. Integração Nacional & $32 \%$ \\
\hline M. Planejamento, Orçamento e Gestão & $27 \%$ & M. Cultura & $24 \%$ \\
\hline M. Aeronáutica & $14 \%$ & M. Meio Ambiente & $23 \%$ \\
\hline \multicolumn{2}{|l|}{1996} & \multicolumn{2}{|c|}{2000} \\
\hline M. Meio Ambiente & $49 \%$ & M. Esporte e Turismo & $69 \%$ \\
\hline M. dos Transportes & $48 \%$ & M. Comunicações & $53 \%$ \\
\hline M. Planejamento, Orçamento e Gestão & $48 \%$ & M. Transportes & $52 \%$ \\
\hline M. dos Esportes & $40 \%$ & M. Integração Nacional & $39 \%$ \\
\hline M. das Comunicações & $13 \%$ & M. Meio Ambiente & $23 \%$ \\
\hline \multicolumn{2}{|l|}{1997} & \multicolumn{2}{|c|}{2001} \\
\hline M. Esporte & $65 \%$ & M. Esporte e Turismo & $66 \%$ \\
\hline M. Transportes & $54 \%$ & M. Transportes & $45 \%$ \\
\hline M. Meio Ambiente & $50 \%$ & M. Meio Ambiente & $35 \%$ \\
\hline M. Planejamento & $45 \%$ & M. Integração Nacional & $31 \%$ \\
\hline M. Cultura & $24 \%$ & M. Comunicações & $31 \%$ \\
\hline \multicolumn{2}{|l|}{1998} & \multicolumn{2}{|c|}{2002} \\
\hline M. Esporte e Turismo & $66 \%$ & M. Esporte e Turismo & $62 \%$ \\
\hline M. Transportes & $43 \%$ & M. Integração Nacional & $38 \%$ \\
\hline M. Integração Nacional & $30 \%$ & M. Cultura & $38 \%$ \\
\hline M. Cultura & $25 \%$ & M. Transportes & $36 \%$ \\
\hline M. Ciência e Tecnologia & $14 \%$ & M. Meio Ambiente & $33 \%$ \\
\hline
\end{tabular}

Fonte: Banco de Dados do Orçamento da União do Cebrap e Siga Brasil 


\begin{tabular}{|c|c|c|c|}
\hline Ministérios & $\begin{array}{l}\text { Porcentagem de } \\
\text { recursos para executar } \\
\text { as emendas }\end{array}$ & Ministérios & $\begin{array}{l}\text { Porcentagem de } \\
\text { recursos para executar } \\
\text { as emendas }\end{array}$ \\
\hline \multicolumn{2}{|l|}{2003} & \multicolumn{2}{|c|}{2007} \\
\hline M. dos Esportes & $57 \%$ & M. Cidades & $79 \%$ \\
\hline M. Cidades & $49 \%$ & M. dos Esportes & $78 \%$ \\
\hline M. Turismo & $46 \%$ & M. Turismo & $76 \%$ \\
\hline M. Transportes & $44 \%$ & M. Transportes & $71 \%$ \\
\hline M. Indústria e Comércio Exterior & $16 \%$ & M. Integração Nacional & $37 \%$ \\
\hline \multicolumn{2}{|l|}{2004} & \multicolumn{2}{|c|}{2008} \\
\hline M. dos Esportes & $76 \%$ & M. Cidades & $88 \%$ \\
\hline M. Turismo & $63 \%$ & M. dos Esportes & $74 \%$ \\
\hline M. Transportes & $61 \%$ & M. Turismo & $72 \%$ \\
\hline M. Cidades & $58 \%$ & M. Transportes & $71 \%$ \\
\hline M. Integração Nacional & $32 \%$ & M. Integração Nacional & $36 \%$ \\
\hline \multicolumn{2}{|l|}{2005} & \multicolumn{2}{|c|}{2009} \\
\hline M. dos Esportes & $69 \%$ & M. Integração Nacional & $81 \%$ \\
\hline M. Turismo & $59 \%$ & M. Transportes & $76 \%$ \\
\hline M. Transportes & $58 \%$ & M. dos Esportes & $70 \%$ \\
\hline M. Cidades & $52 \%$ & M. Turismo & $64 \%$ \\
\hline M. Integração Nacional & $24 \%$ & M. Pesca e Aquicultura & $56 \%$ \\
\hline \multicolumn{2}{|l|}{2006} & \multicolumn{2}{|c|}{2010} \\
\hline M. Turismo & $77 \%$ & M. Integração Nacional & $80 \%$ \\
\hline M. Cidades & $67 \%$ & M. Transportes & $78 \%$ \\
\hline M. Transportes & $66 \%$ & M. dos Esportes & $71 \%$ \\
\hline M. dos Esportes & $51 \%$ & M. Turismo & $57 \%$ \\
\hline M. Cultura & $26 \%$ & M. Pesca e Aquicultura & $52 \%$ \\
\hline
\end{tabular}

Fonte: Banco de Dados do Orçamento da União do Cebrap e Siga Brasil 
Anexo 3: Destino das emendas individuais dos parlamentares que não pertencem a base do governo de acordo com os Ministérios que mais detém recursos em Investimentos (1995-2010)

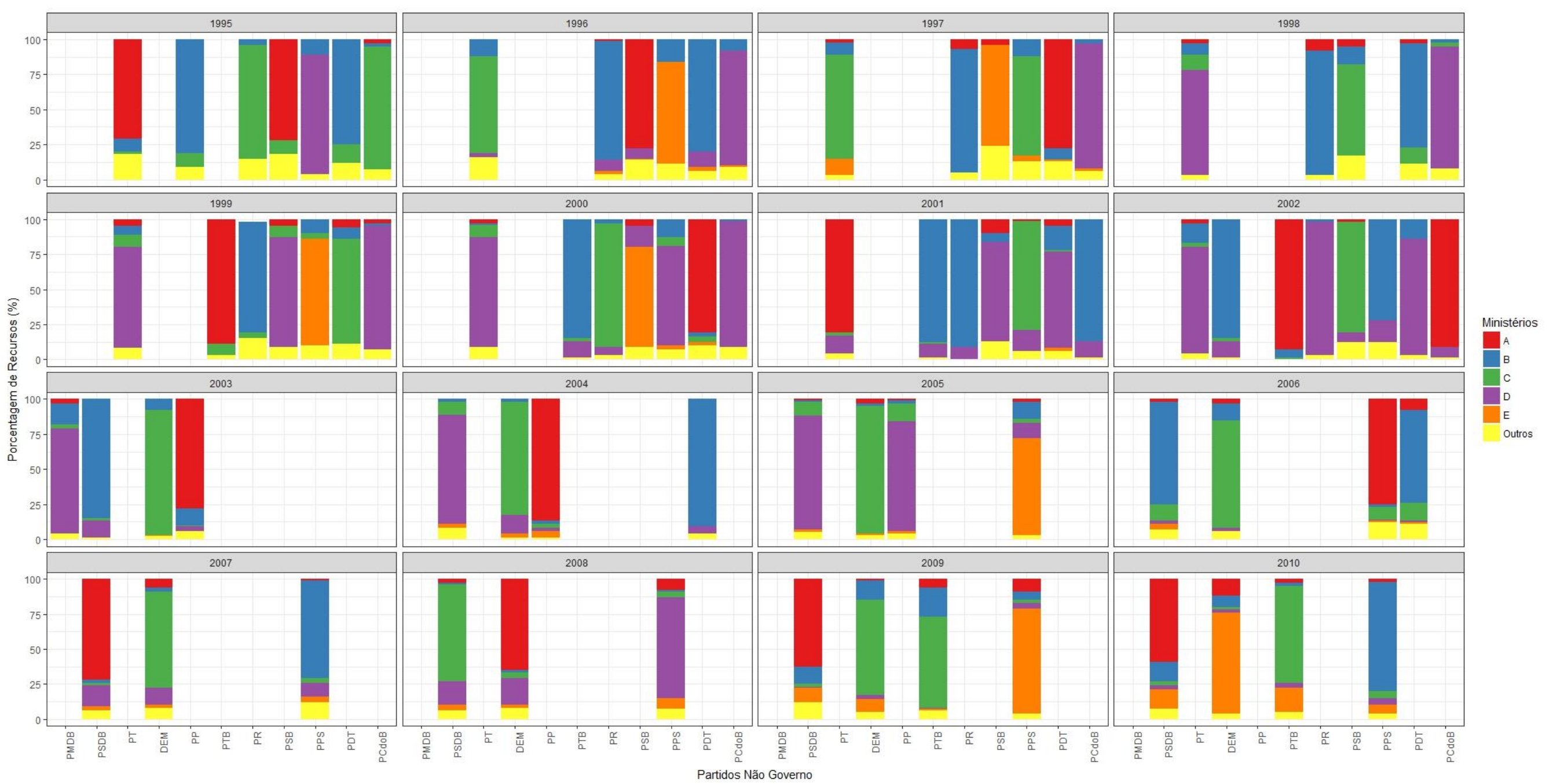

Fonte: Banco de Dados do Orçamento da União do Cebrap e Siga Brasil 